\title{
Woodland and Caddo Period Sites at Toledo Bend Reservoir, Northwest Louisiana and East Texas
}

Timothy K. Perttula

Heritage Research Center, Stephen F. Austin State University

Mark Walters

Heritage Research Center, Stephen F. Austin State University

Follow this and additional works at: https://scholarworks.sfasu.edu/ita

Part of the American Material Culture Commons, Archaeological Anthropology Commons, Environmental Studies Commons, Other American Studies Commons, Other Arts and Humanities Commons, Other History of Art, Architecture, and Archaeology Commons, and the United States History Commons

Tell us how this article helped you.

This Article is brought to you for free and open access by the Center for Regional Heritage Research at SFA ScholarWorks. It has been accepted for inclusion in Index of Texas Archaeology: Open Access Gray Literature from the Lone Star State by an authorized editor of SFA ScholarWorks. For more information, please contact cdsscholarworks@sfasu.edu. 
Woodland and Caddo Period Sites at Toledo Bend Reservoir, Northwest Louisiana and East Texas

\section{Creative Commons License}

(c) (1) (9)

This work is licensed under a Creative Commons Attribution-NonCommercial 4.0 International License 


\title{
Woodland and Caddo Period Sites at Toledo Bend Reservoir, Northwest Louisiana and East Texas
}

\author{
Timothy K. Perttula and Mark Walters
}

\section{INTRODUCTION AND SETTING}

Toledo Bend Reservoir is one of the largest artificial lakes in the United States and the largest reservoir in the South. The lake is approximately 65 miles long and contains over 1200 miles of shoreline in both Louisiana and Texas (Figure 1). Construction began in 1964 with completion of the power plant, with the subsequent filling of the lake in 1969. Archaeological investigations at Toledo Bend Reservoir on the Sabine River and tributaries in both Louisiana and Texas took place primarily took during the 1960s, with survey and excavations, sometimes of a very limited nature (Scurlock and Davis 1962; Scurlock 1964; McClurkan et al. 1966; Jensen 1968a, 1968b; Woodall 1969; Benham et al. 1973) by the University of Texas (UT) and Southern Methodist University (SMU). Girard (1992, 1994, 2007a, 2014) has continued archaeological investigations along the Louisiana side of the reservoir, however, focusing particularly on work at the James Pace site (16DS10/268).

In this article we review the nature of the material culture assemblage of the Woodland and Caddo sites at Toledo Bend Reservoir based on the collections at the Texas Archeological Research Laboratory at The University of Texas at Austin (TARL). This consists of ceramic and/or lithic artifacts from 76 different sites in Louisiana and Texas. We have also examined ceramic vessels from Woodland and Caddo burial features at several Toledo Bend Reservoir sites. Our purpose in re-examining the TARL collections from the Toledo Bend Reservoir is to better understand and characterize the material culture assemblages (primarily decorated ceramic sherds) from sites that date between ca. 2500 years B.P. and the late 17 th-early 18 th century A.D., particularly in light of questions concerning the cultural affiliation and cultural taxonomic relationships of the ancestral Caddo sites in this part of East Texas and western Louisiana (cf. Kelley 2006; Kelley et al. 2010).

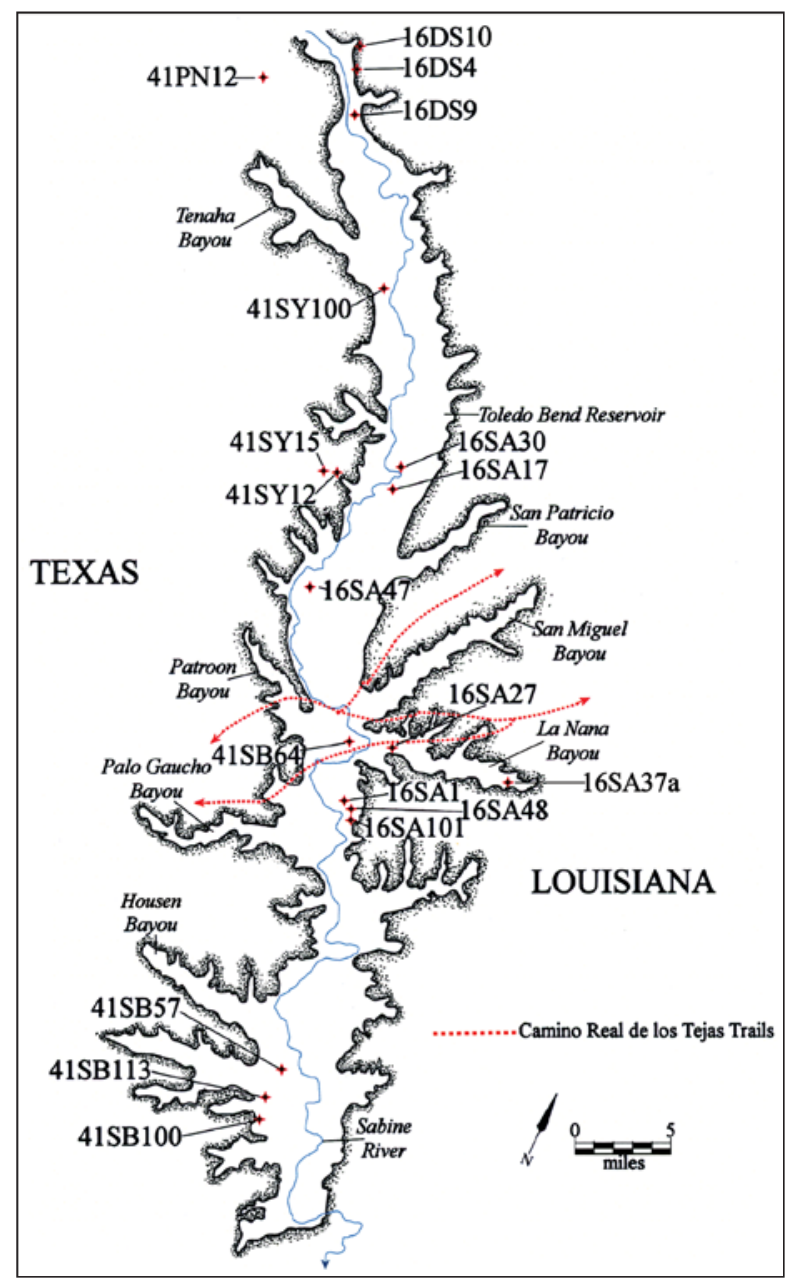

Figure 1. Toledo Bend Reservoir along the Sabine River in Louisiana and Texas, and sites mentioned in the text. 


\section{Louisiana Sites}

The TARL collections from Louisiana sites at Toledo Bend Reservoir include 28 sites and one area in Sabine Parish (Table 1). About 21 percent of the sites have Woodland period components (ca. 2500-1150 years B.P.) with either Goose Creek Plain, var. unspecified sandy paste sherds or early style arrow points (i.e., Friley type, see Anderson and Smith 2003:293 and Figure 5.13cc-gg). More than 96 percent of the Louisiana sites at Toledo Bend Reservoir have grog or bone-tempered Caddo ceramic vessel sherds and/or Caddo style arrow points (i.e., Alba and Perdiz types).

Table 1. Louisiana sites with collections at TARL from Toledo Bend Reservoir.

\begin{tabular}{|c|c|c|c|c|}
\hline Sites & $\begin{array}{l}\text { Woodland period } \\
\text { sherds }\end{array}$ & $\begin{array}{l}\text { Woodland } \\
\text { period AP }\end{array}$ & Caddo sherds & $\begin{array}{l}\text { Caddo AP/ } \\
\text { tools }\end{array}$ \\
\hline $16 \mathrm{DS} 4$ & $\mathrm{x}$ & $\mathrm{x}$ & $\mathrm{x}$ & $\mathrm{x}$ \\
\hline 16DS5 & - & - & $\mathrm{x}$ & - \\
\hline 16DS8 & - & - & $\mathrm{x}$ & - \\
\hline 16DS9 & - & - & $\mathrm{x}$ & - \\
\hline 16DS10/ & - & - & $\mathrm{x}$ & $\mathrm{x}$ \\
\hline \multicolumn{5}{|l|}{ 16DS268 } \\
\hline 16DS11 & - & $\mathrm{x}$ & $\mathrm{x}$ & $\mathrm{x}$ \\
\hline $\begin{array}{l}\text { 16SA, } \\
\text { Area R }\end{array}$ & - & - & $\mathrm{x}$ & - \\
\hline 16SA2 & - & - & $\mathrm{x}$ & - \\
\hline 16SA14 & - & - & $\mathrm{x}$ & - \\
\hline 16SA16 & - & - & $\mathrm{x}$ & $\mathrm{x}$ \\
\hline 16SA17 & - & - & $\mathrm{x}$ & $\mathrm{x}$ \\
\hline 16SA20 & - & - & $\mathrm{x}$ & - \\
\hline 16SA22 & - & - & $\mathrm{x}$ & - \\
\hline 16SA23 & - & - & $\mathrm{x}$ & - \\
\hline 16SA25 & - & - & $\mathrm{x}$ & - \\
\hline 16SA26 & - & - & $\mathrm{x}$ & - \\
\hline 16SA27 & - & - & $\mathrm{x}$ & $\mathrm{x}$ \\
\hline 16SA30, A & $\mathrm{x}$ & $\mathrm{x}$ & $\mathrm{x}$ & $\mathrm{x}$ \\
\hline 16SA31 & - & - & $\mathrm{x}$ & $\mathrm{x}$ \\
\hline 16SA34 & - & - & $\mathrm{x}$ & $\mathrm{x}$ \\
\hline 16SA35 & - & - & - & $\mathrm{x}$ \\
\hline 16SA36 & - & - & $\mathrm{x}$ & - \\
\hline 16SA38 & - & - & $\mathrm{x}$ & - \\
\hline 16SA47 & $\mathrm{x}$ & - & $\mathrm{x}$ & - \\
\hline 16SA100 & - & - & $\mathrm{x}$ & $\mathrm{x}$ \\
\hline 16SA101 & $\mathrm{x}$ & $\mathrm{x}$ & $\mathrm{x}$ & $\mathrm{x}$ \\
\hline 16SA102 & - & - & $\mathrm{x}$ & - \\
\hline 16SA104 & - & - & $\mathrm{x}$ & - \\
\hline $16 \mathrm{VN} 3$ & $\mathrm{x}$ & $\mathrm{x}$ & - & - \\
\hline
\end{tabular}

$\mathrm{AP}=$ arrow point 
The more extensively examined Louisiana sites at Toledo Bend Reservoir are discussed in more detail in the next section. Of the less well known archaeological sites on the Louisiana side of Toledo Bend Reservoir there are two that have Woodland period components. These are:

- $\quad$ 16DS11 (1 Friley arrow point of tan chert); and

- $\quad$ 16VN3 (1 brown chert Friley arrow point and 1 Goose Creek Plain, var. unspecified rim sherd).

Sites with ancestral Caddo components of an unknown age include:

- $\quad$ 16DS5 (1 plain grog-tempered body sherd);

- $\quad$ 16DS8 (1 plain grog-tempered body sherd);

- $\quad$ 16SA---, Area R (1 plain grog-tempered body sherd);

- $\quad$ 16SA14 (3 plain grog-tempered body sherds);

- $\quad$ 16SA25 (4 grog-tempered sherds, including one with a straight incised line decorative element);

- $\quad$ 16SA26 (1 plain grog-tempered body sherd);

- $\quad$ 16SA36 (1 plain bone-tempered body sherd); and

- $\quad$ 16SA38 (1 plain grog-tempered body sherd).

Caddo components that date between ca. A.D. 900-1200 (Formative to Early Caddo periods) on the Louisiana site of Toledo Bend Reservoir are present at:

- $\quad$ 16DS11 (1 Catahoula arrow point and 1 Alba arrow point of red chert);

- $\quad$ 16SA16 (1 Alba arrow point of brownish-red chert and 9 plain grog and bone-tempered sherds);

- 16SA22 (5 grog-tempered sherds, including one zoned incised-punctated body sherd);

- 16SA31 (1 red chert Alba point, 28 plain grog- and bone-tempered sherds, and 3 grog-tempered horizontal incised rim and body sherds);

- $\quad$ 16SA34 (2 brown or red chert Alba arrow points and 22 plain grog- and bone-tempered sherds; 3 incised and tool punctated rim and body sherds may be associated with this component);

- $\quad$ 16SA35 (1 red chert Colbert arrow point); and

- 16SA100 (1 yellowish-brown Alba arrow point and 24 grog and bone-tempered sherds, including pinched sherds and 1 possible Holly Fine Engraved rim sherd [Figure 2].

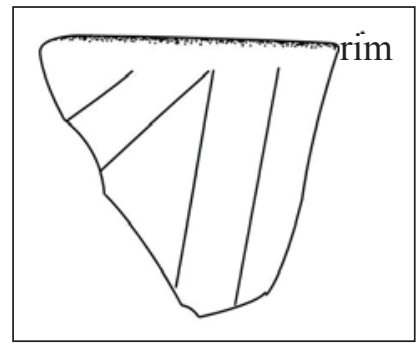

Figure 2. Engraved rim sherd from 16SA100, investigated by SMU in 1967.

Post-A.D. 1200 Caddo components are represented at:

- $16 \mathrm{DS} 11$ (35 grog and bone-tempered sherds, primarily 16 brushed rim and body sherds and 1 brushed-incised grog-tempered sherd);

- 16SA2 (19 grog and bone-tempered sherds, including Belcher Ridged, var. Byram Ferry, a 15th century A.D. utility ware [Girard 2007b], and other sherds with brushed, incised, and brushed-incised decorative elements);

- 16SA34 (2 bone-tempered brushed body sherds); 
- 16SA102 (11 grog- and none-tempered sherds, including 2 brushed sherds); and

- $\quad$ 16SA104 (5 bone- and grog-tempered sherds, including 1 brushed sherd).

It is possible that a post-A.D. 1500 Caddo component is present at the following poorly known Toledo Bend Reservoir site:

- $\quad$ 16SA23 (8 grog-tempered sherds, including Belcher Ridged, var. Belcher).

\section{Haddens Bend Site (16DS4)}

The Haddens Bend site was first located and investigated by Scurlock and Davis (1962:40). The site is on a bluff overlooking the Sabine River, and the bluff cut showed between 60-120 cm of tan sands overlying a clay subsoil. Scurlock (1964:17-20) reported on the test excavations at the site, and archaeological deposits were identified over a ca. $140 \mathrm{~m}$ area of the bluff, with the deposits reaching ca. $110 \mathrm{~cm}$ bs; no midden deposits were identified in the work.

SMU's work at the Haddens Bend site included the excavation of five backhoe trenches and a series of 2 x 2 m excavation units (Figure 3; see Jensen 1968b:Figure 2). These excavations encountered sandy archaeological deposits about $1 \mathrm{~m}$ in thickness (Jensen 1968b:5 and Figure 3).

The ceramic assemblage from the site includes sandy paste Goose Creek Plain and decorated sherds (9.8 percent of the sherd sample), a grog-tempered ware ( 74 percent), a bone-tempered ware (15.5 percent), and a shell-tempered ware ( 0.5 percent; both sherds are plain) (Table 2$)$. The decorated sherds are concentrated in what are primarily grog- and bone-tempered Caddo vessel sherds, but there are also two grog-tempered Marksville Incised sherds in the Haddens Bend ceramics.

Table 2. Ceramic assemblage from the Haddens Bend site (16DS4).

\begin{tabular}{llllll}
\hline Ceramics & $\begin{array}{l}\text { Sandy } \\
\text { Paste }\end{array}$ & $\begin{array}{l}\text { Grog- } \\
\text { tempered }\end{array}$ & $\begin{array}{l}\text { Bone- } \\
\text { tempered }\end{array}$ & $\begin{array}{l}\text { Shell- } \\
\text { tempered }\end{array}$ & N \\
\hline Plain & 36 & 246 & 43 & 2 & 327 \\
Decorated & 3 & 50 & 19 & - & 72 \\
\hline Totals & 39 & 296 & 62 & 2 & 399 \\
\hline
\end{tabular}

The sandy paste ceramics from the site include plain rim, body, and base sherds $(n=34)$, two body sherds or spindle whorls with drilled holes $(6-13 \mathrm{~mm}$ in diameter), and three decorated sherds. The first is a rim sherd with lip notching; lip notched sandy paste sherds appear to be most abundant in pre-A.D. 300 contexts at sites in East Texas (cf. Perttula 2008:433). The other two decorated sherds are from Goose Creek Incised, var. unspecified or var. Neches sherds (cf. Aten and Bollich 2011:157) with broad U-shaped curvilinear, rectilinear, and horizontal incised elements (Figure 4a-b); the decorations are certainly reminiscent of those seen on grog-tempered Marksville Incised vessels in the Lower Mississippi Valley (cf. Brown 1998:16), especially Marksville Incised, var. Sunflower, which was made from ca. 100 B.C. to A.D. 100. The lip notched and incised sandy paste sherds from the Haddens Bend site suggest the site was occupied contemporaneously with the early Marksville period (ca. 100 B.C.-A.D. 100).

There are also grog-tempered Marksville Incised, var. unspecified and Marksville Stamped, var. unspecified body sherds in the assemblage (Figure 5a-b). The stamped sherd has one broad curvilinear incised line and a zone of dentate stamping. The incised sherd has broad U-shaped opposed lines. 


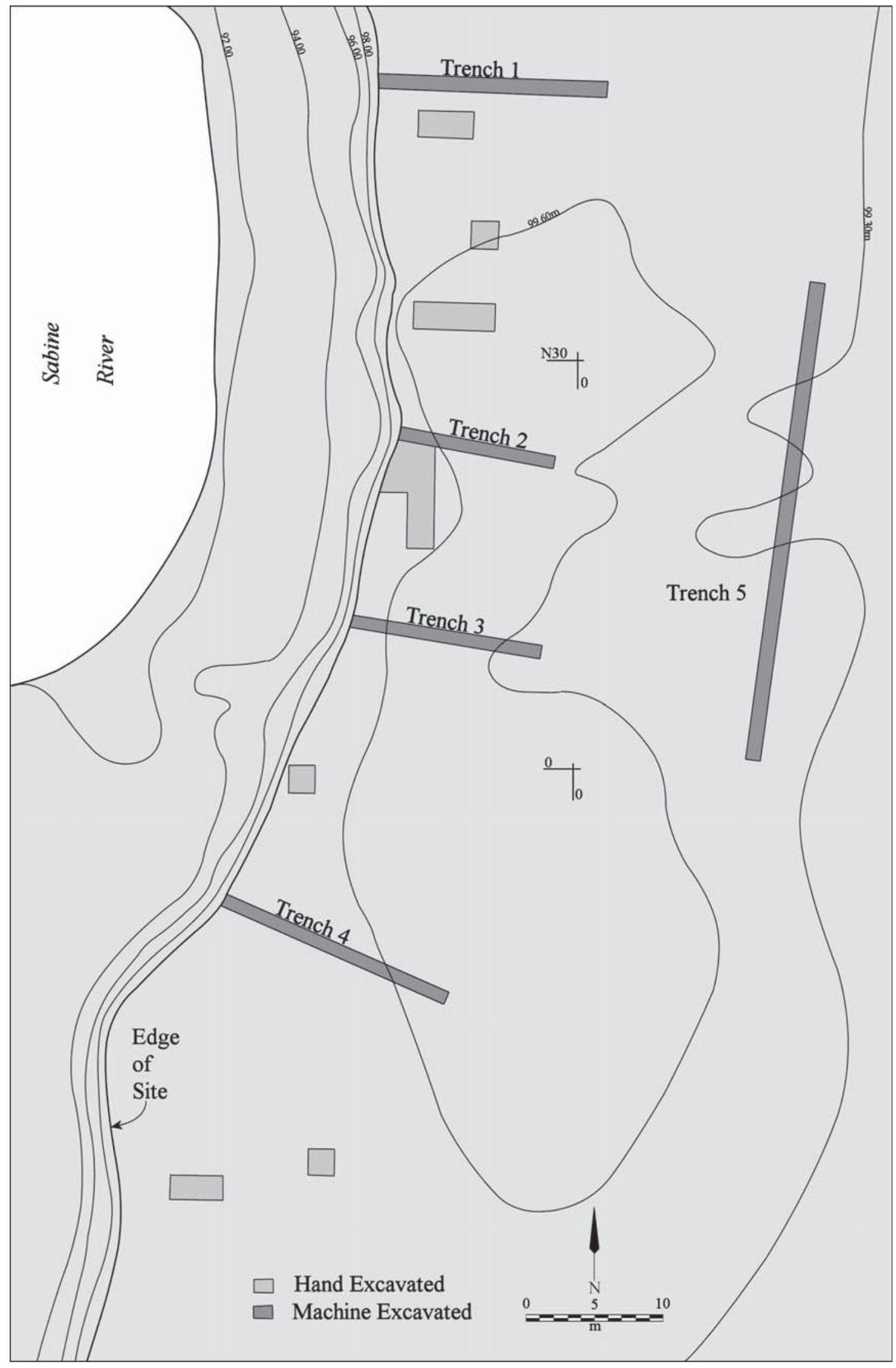

Figure 3. Map of SMU excavations at the Haddens Bend site (16DS4). 


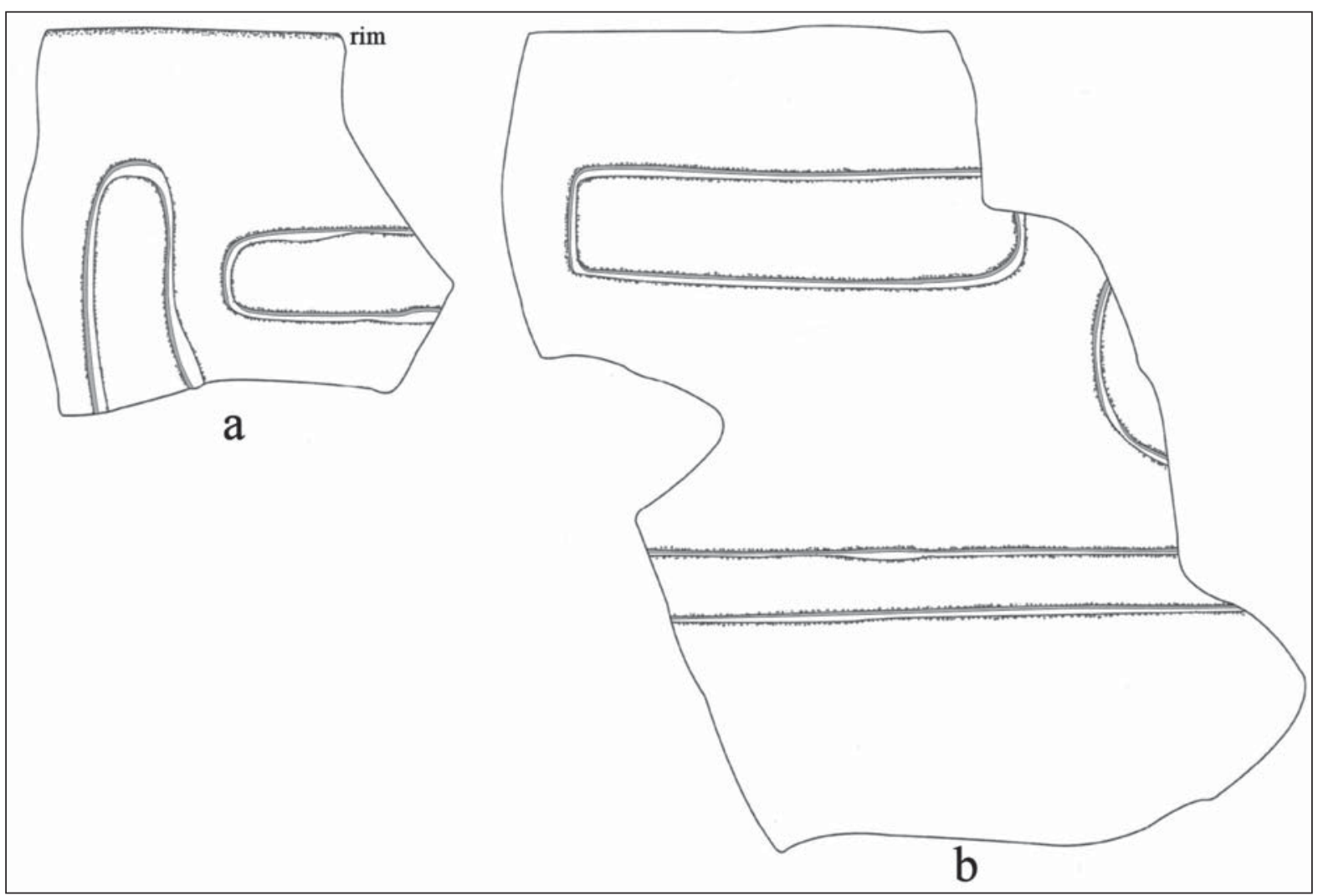

Figure 4. Goose Creek Incised, var. unspecified rim sherds from the Haddens Bend site.

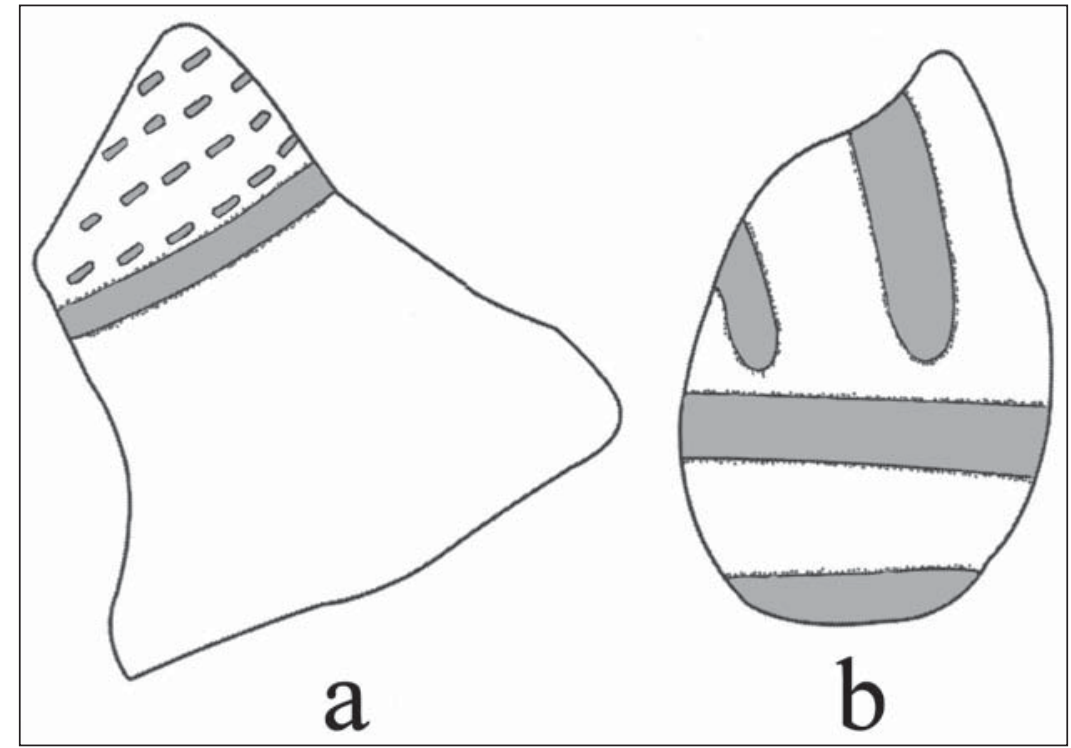

Figure 5. Marksville Incised and Marksville Stamped sherds from the Haddens Bend site. 
The decorated sherds from the Caddo occupation(s) at the Haddens Bend site are dominated by sherds from vessels decorated with brushing marks (Table 3). More than 67 percent of the decorated rim and body sherds have brushing marks; 9 percent are brushed-appliqued sherds from Pease Brushed-Incised vessels (Figure 6a-b), and 4.5 percent have brushed-punctated decorative elements. This proportion of brushed sherds in the utility wares suggests that the principal Caddo occupation took place in the Late Caddo period, perhaps between ca. A.D. 1400-1500 (given the absence of Belcher Ridged, var. Belcher sherds, cf. Girard 2007b).

Table 3. Decorative methods and elements in the Caddo ceramic sherd assemblage from the Haddens Bend site (16DS4).

\begin{tabular}{llll}
\hline $\begin{array}{l}\text { Decorative method/ } \\
\text { elements }\end{array}$ & Rim & Body & N \\
\hline
\end{tabular}

\section{Utility Ware}

Brushed

horizontal brushing marks

opposed brushing marks

overlapping brushing marks

parallel brushing marks

$\begin{array}{lll}4 & - & 4 \\ 1 & 2 & 3 \\ - & 1 & 1 \\ - & 37 & 37 \\ & & \\ - & & 4 \\ - & 4 & 1 \\ - & 1 & 1\end{array}$

Brushed-Appliqued

straight appliqued fillet and opposed brushing marks straight appliqued fillet and parallel brushing marks vertical appliqued fillet and horizontal and opposed brushing marks

\section{Brushed-Punctated}

horizontal brushing and tool punctated row under the

lip and through the brushing

parallel brushing and tool punctated row through

$-1$

the brushing

\section{Incised}

horizontal and diagonal lines

nested opposed lines

parallel lines

straight line

$\begin{array}{lll}- & 1 & 1 \\ - & 2 & 2 \\ - & 5 & 5 \\ - & 1 & 1\end{array}$

\section{Incised-Punctated}

diagonal incised panel with tool punctates

$\begin{array}{lll}- & 1 & 1\end{array}$

\section{Lip Notched}

\section{Punctated}

tool punctated row/rows

$\begin{array}{lll}- & 1 & 1\end{array}$

Fine Ware

\section{Engraved}

vertical engraved lines 


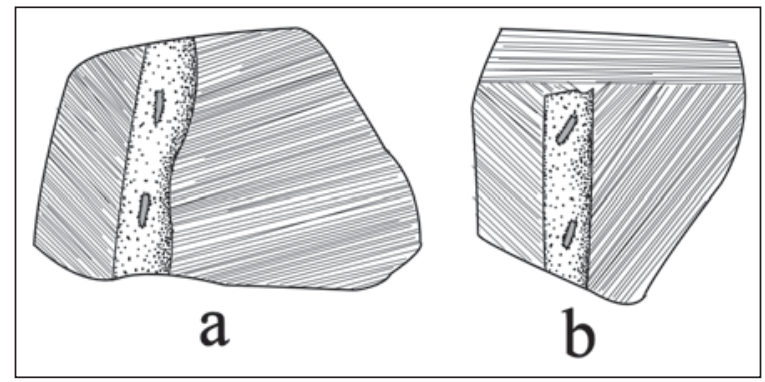

Figure 6. Brushed-appliqued body sherds from the Haddens Bend site.

Sherds from incised vessels account for 13 percent of the decorated sherds in the Caddo assemblage (see Table 3). There are single examples of temporally undiagnostic incised-punctated, punctated, lip notched, and engraved sherds at the site.

The lithic artifacts from the site are from late Woodland (after ca. A.D. 700) and Early Caddo period components. The late Woodland tool is a red chert Friley arrow point. The later tools include a red chert Catahoula arrow point, a possible Colbert point fragment made from a reddish-brown chert, and a red chert arrow point blade.

\section{$16 D S 9$}

This prehistoric site was on a sandy bluff overlooking the confluence of the Sabine River and Castor Creek (Scurlock and Davis 1962:42). UT excavations were carried out in 1963, primarily in a 3 x $20 \mathrm{ft}$. trench (Scurlock 1964:21). Archaeological deposits extended to ca. $60 \mathrm{~cm}$ bs.

The collections at TARL from 16DS9 include a variety of plain and decorated ceramics from bone- and grog-tempered vessels (Table 4). About 95 percent of the sherds from the three wares are from grog-tempered vessels; only the plain wares have any bone-tempered sherds.

Table 4. Ceramic sherds from 16DS9.

\begin{tabular}{llll}
\hline Ware & $\begin{array}{l}\text { Grog- } \\
\text { tempered }\end{array}$ & $\begin{array}{l}\text { Bone- } \\
\text { tempered }\end{array}$ & $\mathrm{N}$ \\
\hline Plain & 57 & 5 & 62 \\
Utility & 38 & - & 38 \\
Fine & 5 & - & 5 \\
\hline Totals & 100 & 5 & 105 \\
\hline
\end{tabular}

The decorated sherds from 16DS9 are primarily from utility ware vessels, comprising 88 percent of the assemblage ( $\mathrm{n}=43$ decorated sherds). These are from vessels with incised $(\mathrm{n}=26)$, incised-punctated $(\mathrm{n}=7)$, and punctated $(\mathrm{n}=5)$ decorative elements (Table 5). The few fine ware sherds are from engraved or redslipped vessels. The various decorated sherds from 16DS9, including Crockett Curvilinear Incised, Davis Incised, and Hickory Engraved sherds (see below), suggest that the Caddo occupation of the site took place between ca. A.D. 900-1200. 
Table 5. Decorative elements on utility ware and fine ware sherds from 16DS9.

\begin{tabular}{|c|c|c|c|}
\hline $\begin{array}{l}\text { Method/ } \\
\text { Decorative element }\end{array}$ & Rim & Body & $\mathrm{N}$ \\
\hline \multicolumn{4}{|l|}{ Utility Ware } \\
\hline \multicolumn{4}{|l|}{ Incised } \\
\hline diagonal lines & 1 & - & 1 \\
\hline horizontal lines & 5 & - & 5 \\
\hline opposed lines & - & 6 & 6 \\
\hline parallel lines & - & 14 & 14 \\
\hline \multicolumn{4}{|l|}{ Incised-Punctated } \\
\hline $\begin{array}{l}\text { curvilinear incised panel filled with tool } \\
\text { punctates }\end{array}$ & - & 2 & 2 \\
\hline $\begin{array}{l}\text { parallel incised lines adjacent to zone of tool } \\
\text { punctates }\end{array}$ & - & 5 & 5 \\
\hline \multicolumn{4}{|l|}{ Punctated } \\
\hline tool punctated rows & 1 & 4 & 5 \\
\hline \multicolumn{4}{|l|}{ Fine Ware } \\
\hline \multicolumn{4}{|l|}{ Engraved } \\
\hline cross-hatched zone & - & 1 & 1 \\
\hline horizontal engraved lines & 1 & - & 1 \\
\hline $\begin{array}{l}\text { horizontal line and hatched and open } \\
\text { triangle elements }\end{array}$ & 1 & - & 1 \\
\hline \multicolumn{4}{|l|}{ Red-Slipped } \\
\hline int./ext. red-slipped & - & 2 & 2 \\
\hline Totals & 9 & 34 & 43 \\
\hline
\end{tabular}

The incised rim sherds in the 16DS9 assemblage are from Davis Incised and Dunkin Incised vessels with either horizontal or diagonal incised decorative elements (see Table 5). Two of the incised-punctated body sherds are from Crockett Curvilinear Incised vessels that have curvilinear incised panels filled with tool punctations (Figure 7a).

The fine ware sherds are from vessels with either engraved or red-slipped decorative elements (see Table 5). One rim has widely spaced horizontal engraved lines, and is from a Hickory Engraved vessel (see Figure $7 b$ ). The other engraved rim has hatched and open triangle elements, with the hatched triangle pendant from a horizontal line below the lip (Figure 7c). The body sherd has a cross-hatched zone, possibly an upper fill zone for a slanting scroll motif. The two red-slipped sherds are from grog-tempered bowls or carinated bowls.

\section{James Pace Site (16DS10)}

Scurlock and Davis (1962:42-43) located the James Pace site in a grass-covered field ("The Old Pace Field"), an alluvial terrace in the Sabine River valley. They noted four probable mounds and an adjacent village archaeological deposit over a ca. $90 \times 50 \mathrm{~m}$ area. The largest of the mounds was ca. $15.2 \mathrm{~m}$ in diameter and $1.5 \mathrm{~m}$ in height. 


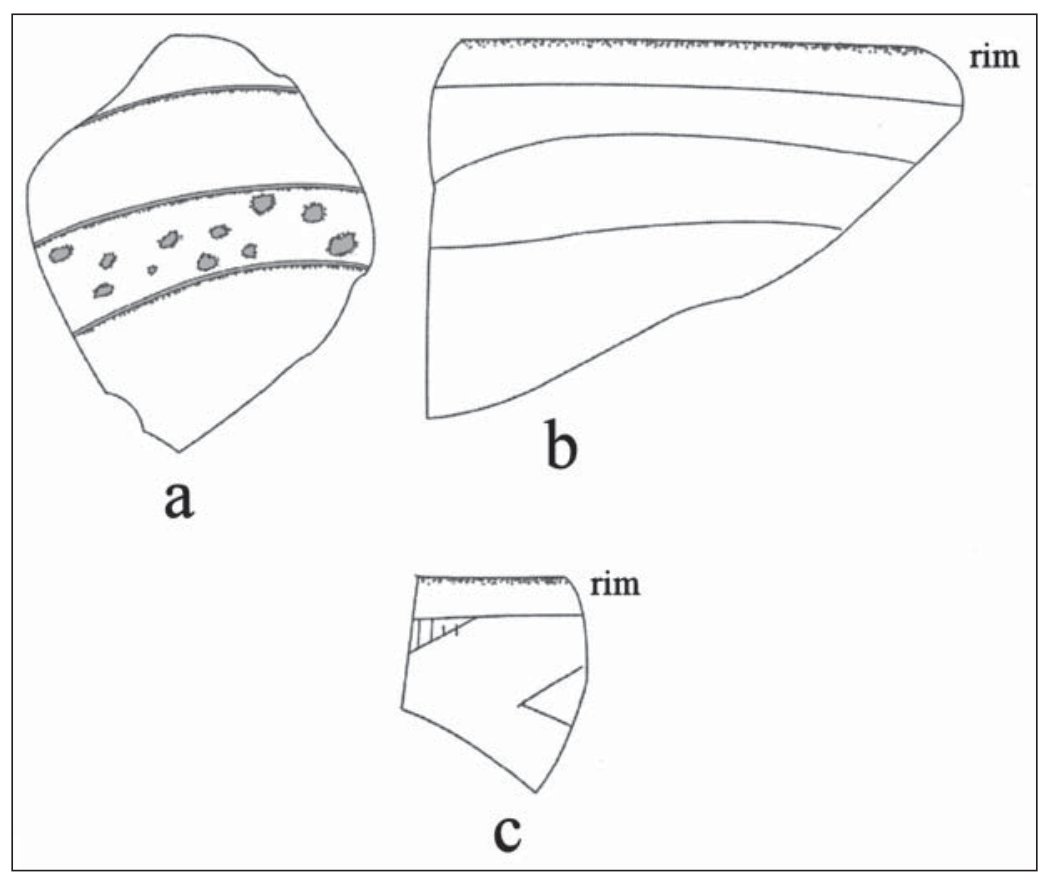

Figure 7. Decorative elements on selected sherds from 16DS9: a, incised-punctated body sherd; b-c, rim sherds.

UT test excavations focused on identifying habitation areas around the mounds (Scurlock 1964:22). They succeeded in finding deposits less than $30 \mathrm{~cm}$ in thickness in a shallow sandy zone; no midden deposits were found in the work.

SMU returned to the James Pace site during the 1966-1967 season and concentrated excavations in habitation areas between two of the mounds (Jensen 1968b:Figure 6; see also Girard 2014:Figure 2). The excavations consisted of five lengthy backhoe trenches and $162 \times 2$ or $1 \times 4 \mathrm{~m}$ units (Figure 8).

The archaeological deposits were about 30-40 cm in thickness, described as a sandy silt, and the deposits were midden stained in some areas (Jensen 1968b:31). One flexed burial (Burial 1) with no associated funerary offerings was encountered in Backhoe Trench 2 at a depth of $30 \mathrm{~cm}$ bs; a single plain grog-tempered body sherd in the fill of Burial 1 suggests that it is a Caddo burial feature. A clay hearth was identified at 40 $\mathrm{cm}$ bs in one of the hand-excavated units between Backhoe Trenches 1 and 2 (see Figure 8). A total of 14 wall-sized (15-25 cm in diameter) postholes were recognized between 9-24 cm bs (Jensen 1968b:Table 9), but they formed no obvious structural patterns (see Figure 8).

A limited and pre-A.D. 800 Woodland period use of the James Pace site is represented by two Goose Creek Plain, var. unspecified body sherds. The remainder of the ceramic assemblage ( $\mathrm{n}=2841$ sherds) is associated with a ca. A.D. 800-1050 Caddo occupation (e.g., Girard 2014:75), and the sherds in this assemblage are from vessels tempered with grog or bone (Table 6). About 86 percent of the sherds are from grog-tempered vessels, and the highest percentage of grog tempering occurs in the fine wares ( 90.4 percent); the highest proportion of bone-tempered sherds is in the plain ware (16.5 percent). One grog-tempered plain rim has a $7 \mathrm{~mm}$ drilled suspension hole. 


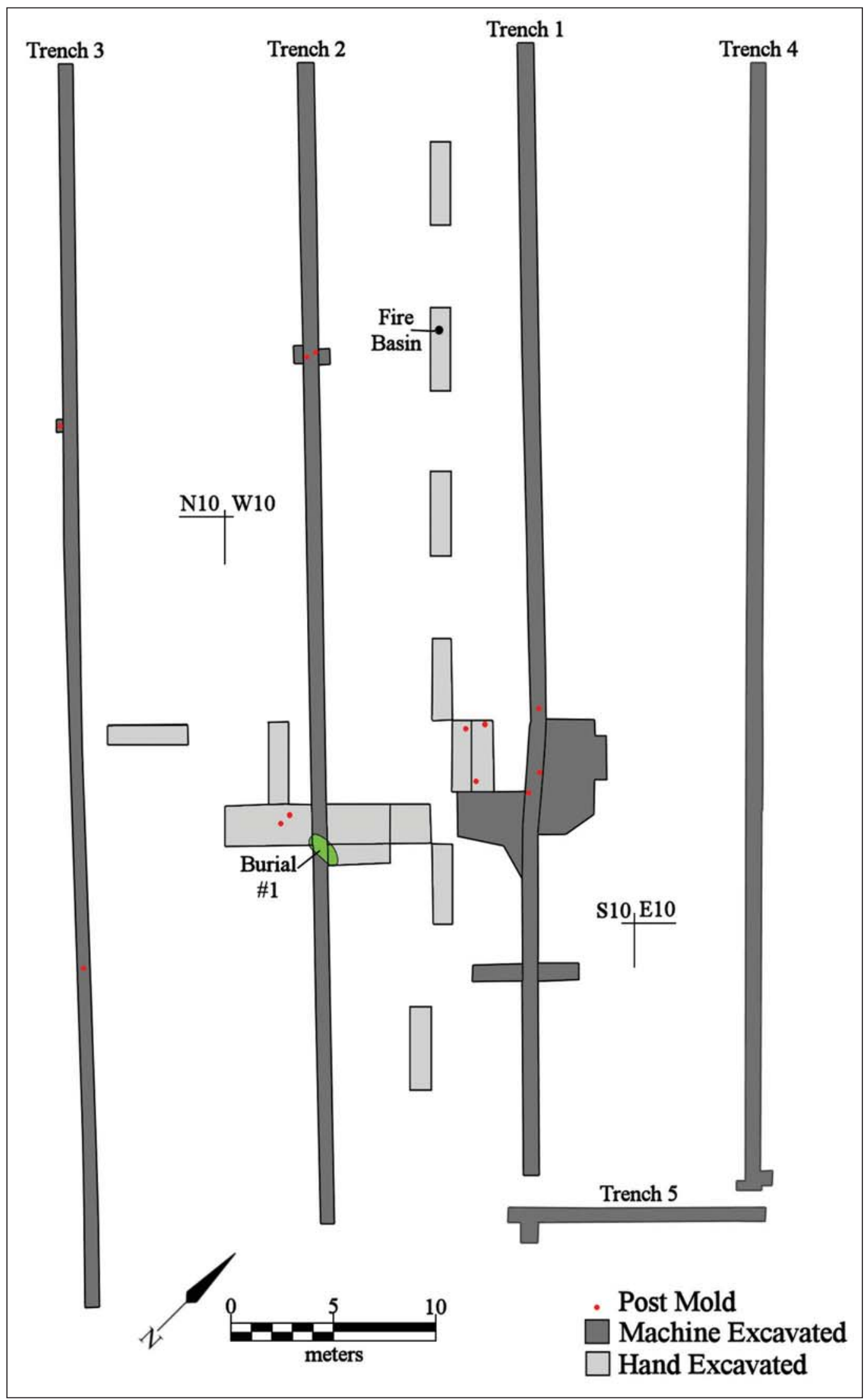

Figure 8. Excavations by SMU at the James Pace site (16DS10). 
Table 6. Ceramic sherd assemblage from the James Pace site (16DS10).

\begin{tabular}{lccc}
\hline Ware & grog-tempered & bone-tempered & N \\
\hline Plain* & 198 & 39 & 237 \\
Utility & 257 & 39 & 296 \\
Fine & 47 & 5 & 52 \\
\hline Totals & 502 & 83 & 585 \\
\hline
\end{tabular}

*this does not include 2256 plain body and base sherds from the SMU excavations in which temper analysis was not conducted

The plain to decorated sherd ratio for the assemblage is a high 7.16. The 348 decorated sherds from the James Pace site are primarily from utility wares ( 85 percent); fine wares only represent 15 percent of the decorated sherds in the assemblage. By way of comparison, in the ceramic assemblage documented by Girard (2014:Table 2) from excavations in Mounds A and B at the site, the plain to decorated sherd ratio is 6.81 . Sherds from utility ware vessels represented 89 percent of the 37 decorated sherds in this small sample from the site.

In the analyzed sample of decorated sherds from the James Pace site, sherds from vessels with incised decorative elements comprise 73 percent of the assemblage (Table 7) as well as 74 percent of all the rim sherds. Sherds with incised-punctated decorative elements only represent 8.2 percent of the assemblage (and 8.6 percent of the rim sherds), followed by other utility wares with lesser proportions: tool punctated (1.8 percent; 4.3 percent of the rim sherds); pinched ( 0.6 percent; 1.4 percent of the rims); and lip notched ( 0.3 percent; 1.4 percent of the rim sherds). Sherds from fine ware vessels comprise 15.5 percent of all the decorated sherds and 10 percent of the rim sherds.

Table 7. Decorative methods and elements represented in the utility ware and fine ware sherds from the James Pace site (16DS10).

\begin{tabular}{llll}
\hline $\begin{array}{l}\text { Decorative method/ } \\
\text { decorative element }\end{array}$ & Rim & Body & \\
\hline Utility Ware & & & \\
Incised & & 3 & 3 \\
cross-hatched lines & - & - & 1 \\
diagonal lines & 1 & 8 & 28 \\
horizontal lines & 20 & - & 2 \\
horizontal lines and straight lip line & 2 & - & 6 \\
horizontal lip line & 6 & - & 3 \\
horizontal lip lines (2 lines) & 1 & 1 & 1 \\
horizontal and diagonal lines & 2 & - & 1 \\
horizontal and vertical lines & 1 & 1 & 79 \\
opposed lines & - & 79 & 1 \\
parallel lines & - & 8 & 86 \\
straight line & - & 1 & 23 \\
tear drop-shaped el. & - & 67 & \\
& & 23 & \\
horizontal lines (overhanging) & 19 & & \\
parallel lines (overhanging) & - & & \\
& & & \\
\end{tabular}


Table 7. Decorative methods and elements represented in the utility ware and fine ware sherds from the James Pace site (16DS10), cont.

\begin{tabular}{llll}
\hline $\begin{array}{l}\text { Decorative method/ } \\
\text { decorative element }\end{array}$ & Rim & Body & $N$ \\
\hline
\end{tabular}

\section{Incised-Punctated}

cross-hatched lines/diamond element with tool

punctates within diamond el. cross-hatched lines above row of tool punctates

horizontal lines with impressed triangle punctates

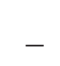

2

between lines

horizontal and diamond-shaped lines and circular

zone filled with small tool punctates

parallel lines and triangular tool punctates

single fingernail punctate on rim; straight lip line

zones of tool punctations divided by horizontal and

vertical lines

zones of tool punctations divided by straight line

horizontal lines (overhanging) and impressed triangle

punctates

horizontal lines (overhanging) and tool punctates

parallel lines (overhanging) and triangular tool

punctates

1

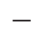

1

$-$

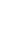

$-$

$-$
2

Punctated

tool punctated, diagonal rows

tool punctated row on the lip

tool punctated rows

tool punctated, random orientation

Subtotal, Utility Ware
1

1

1

63

$-$

1

3

1

2

1

1

1

7

2

6

1

Fine Ware

\section{Engraved}

horizontal lines

horizontal and curvilinear lines

horizontal and diagonal lines

opposed lines

opposed curvilinear lines

parallel lines

straight line

$\begin{array}{lll}5 & - & 5 \\ 1 & - & 1 \\ 1 & - & 1 \\ - & 2 & 2 \\ - & 1 & 1 \\ - & 10 & 10 \\ - & 31 & 31\end{array}$


Table 7. Decorative methods and elements represented in the utility ware and fine ware sherds from the James Pace site (16DS10), cont.

\begin{tabular}{llll}
\hline $\begin{array}{l}\text { Decorative method/ } \\
\text { decorative element }\end{array}$ & Rim & Body & N \\
\hline Subtotal, Fine Ware & 7 & 44 & 51 \\
\hline Totals & 70 & 260 & $330^{*}$ \\
\hline
\end{tabular}

*does not include 18 sherds where the decorative element was not identified during the analysis

The sherds from incised vessels at the James Pace site can be readily divided between those that have overhanging lines ( $\mathrm{n}=109,45$ percent of the incised sherd sample) and those that do not have overhanging lines ( $\mathrm{n}=134,55$ percent) (see Table 7). Almost 48 percent of the rim and body sherds have multiple horizontal incised lines, particularly those with overhanging lines, and are most likely from several varieties of Coles Creek Incised, including var. Blakely, var. Greenhouse, var. Hardy, and var. Mott (cf. Girard 2014:70).

Two Coles Creek Incised rim sherds in the assemblage have a single incised lip line, likely from var. Campbellsville vessels. Seven other rims have only one or two incised lip lines; the rims themselves are plain (see Table 7). One unique plain rim has a row of small tool punctates on the lip.

Other incised sherds in the James Pace site ceramic assemblage have diagonal and horizontal-diagonal elements (Figure 9b-d), perhaps from Dunkin Incised vessels. Another has a horizontal incised panel filled with diagonal incised lines (Figure 9a).

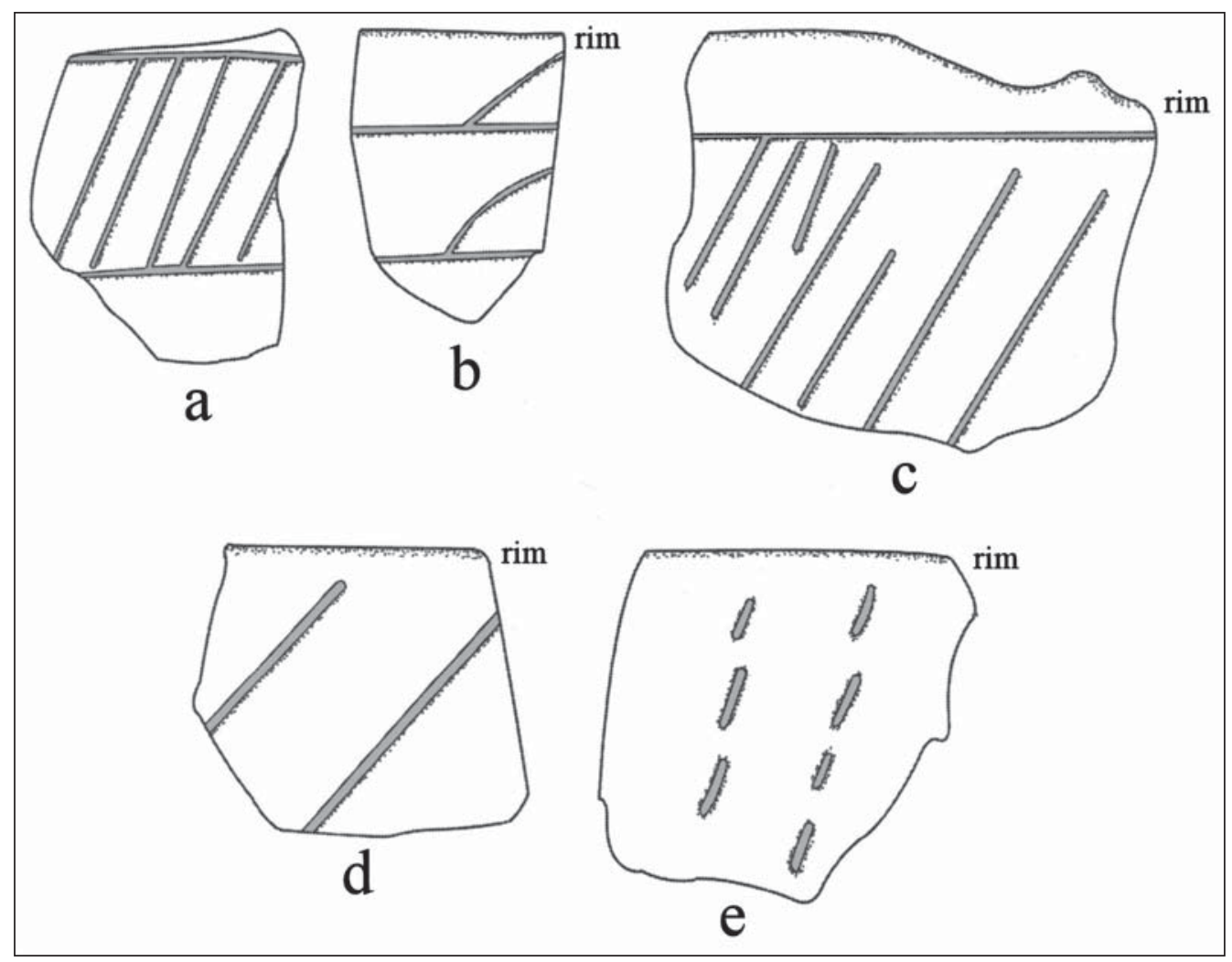

Figure 9. Selected decorative elements on incised and punctated rim and body sherds from the James Pace site: a-d, incised; e, tool punctated. 
Two distinctive rim and lower rim sherds have band punctated decorative elements (Figure 10a-b). These have horizontal incised lines with impressed triangular punctations between the incised lines. This decorative element is noted in ceramic assemblages at Early Caddo sites in East Texas (Newell and Krieger 1949:Figure 38m-n; Bruseth and Perttula 2006:Figure 26d; Perttula 2011:Figure 35b) and Northwest Louisiana (see Webb 1963:Figure 9r-s, u).

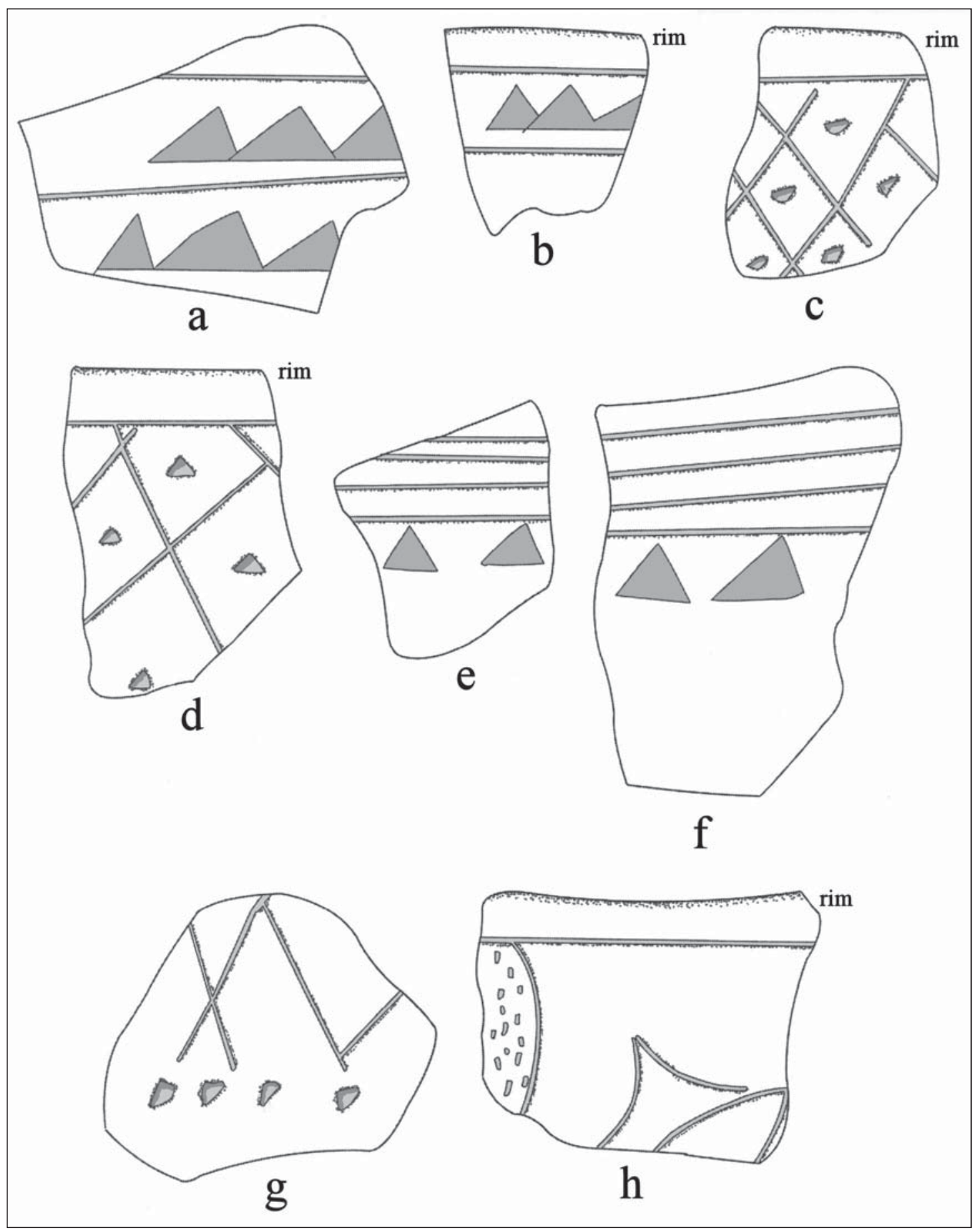

Figure 10. Selected decorative elements on incised-punctated rim and body sherds: $a-b$, band punctated; c-d, Beldeau Incised, var. Beldeau; e-f, Coles Creek Incised, var. Coles Creek; g, Mazique Incised, var. unspecified; h, rim sherd. 
Twenty incised-punctated sherds, mainly with overhanging incised lines, are from Coles Creek Incised, var. Coles Creek vessels. These sherds have horizontal incised lines above a row of large impressed triangles (see Figure 10e-f). Three other incised-punctated sherds have cross-hatched and diamond-shaped incised elements with triangular-shaped tool punctations placed at the center of each of the diamonds (see Figure 10c-d). These sherds are from Beldeau Incised, var. Beldeau vessels (see Brown 1998:13). One lower rim sherd from a Mazique Incised, var. unspecified vessel has cross-hatched incised lines above a row of tool punctates at the rim-body juncture (see Figure 10g). A unique decorative element on a vessel rim sherd has horizontal and diamond-shaped incised lines that bound a circular incised zone filled with small tool punctates (see Figure 10h).

Other utility wares in the assemblage include a lip notched vessel, two Hollyknowe Ridge Pinched rim and body sherds (see Phillips 1970:88-90), and six tool punctated rim and body sherds. These have horizontal and diagonal rows of tool punctations (see Figure 9e), as well as randomly oriented punctations (see Table 7). These tool punctated sherds may be from Evansville Punctated, var. Rhinehart vessels (see Brown 1998:29).

The majority of the engraved rims from the James Pace site ceramic assemblage have horizontal lines (see Table 7) and are likely from Hickory Engraved vessels (see Suhm and Jelks 1962:Plate 36). The other two rims are from different Holly Fine Engraved vessels (Figure 11b-c). One distinctive body sherd has opposed curvilinear engraved lines (Figure 11a), and may also be from a Holly Fine Engraved vessel.

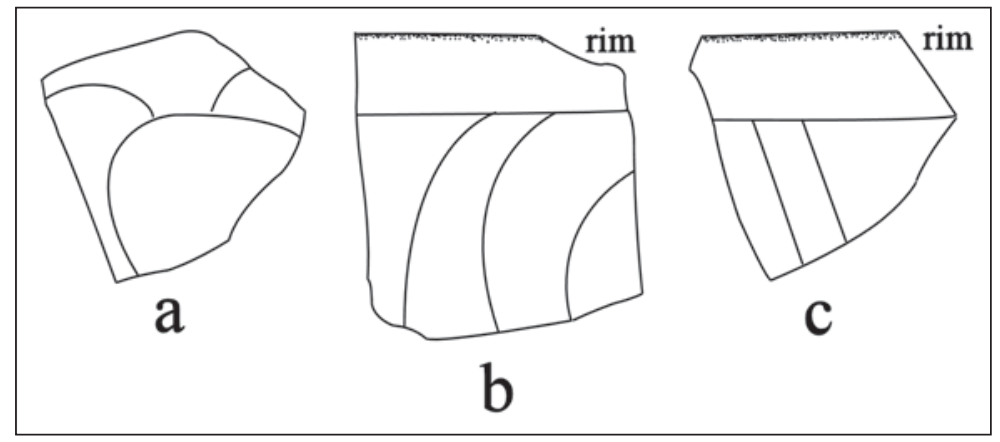

Figure 11. Selected decorative elements on engraved sherds from the James Pace site: a, opposed curvilinear lines; b-c, Holly Fine Engraved rim sherds.

The 14 arrow points recovered from the James Pace site during the SMU investigations include one red chert Homan point and 13 Alba points. About 93 percent of the arrow points are made on local gravels (see Girard 2014:73), including: red chert $(\mathrm{n}=6)$, brown chert $(\mathrm{n}=4)$, quartzite $(\mathrm{n}=2)$, and petrified wood $(\mathrm{n}=1)$. One of the Alba points was manufactured from Manning Fused Glass, a rare East Texas lithic raw material source (see Brown 1976).

\section{$16 \mathrm{SA17}$}

This site, about 1 acre in size when found, was described by Scurlock and Davis (1962:45) as being on a sandy ridge at a spring called Robert Springs. SMU carried out excavations at the site during the 1967-1968 season. Benham et al. (1973:37) describe the site as occurring on an alluvial terrace (160 ft. amsl) about 1.2 $\mathrm{km}$ east of the channel of the Sabine River.

The excavations at the site consisted of $331 \times 10 \mathrm{~m}$ shovel-scraped trenches, three backhoe trenches, and several shovel-scraped units (Benham et al. 1973:Figure 6). The archaeological deposits at 16SA17 were about $40 \mathrm{~cm}$ in thickness, and there was a gray midden zone with charcoal and ash between ca. 18-27 $\mathrm{cm}$ bs. Features identified in the work included five burials and two cremations (in artifact cluster 3), several pits, and two areas with post holes from structures (artifact clusters 1 and 4) 


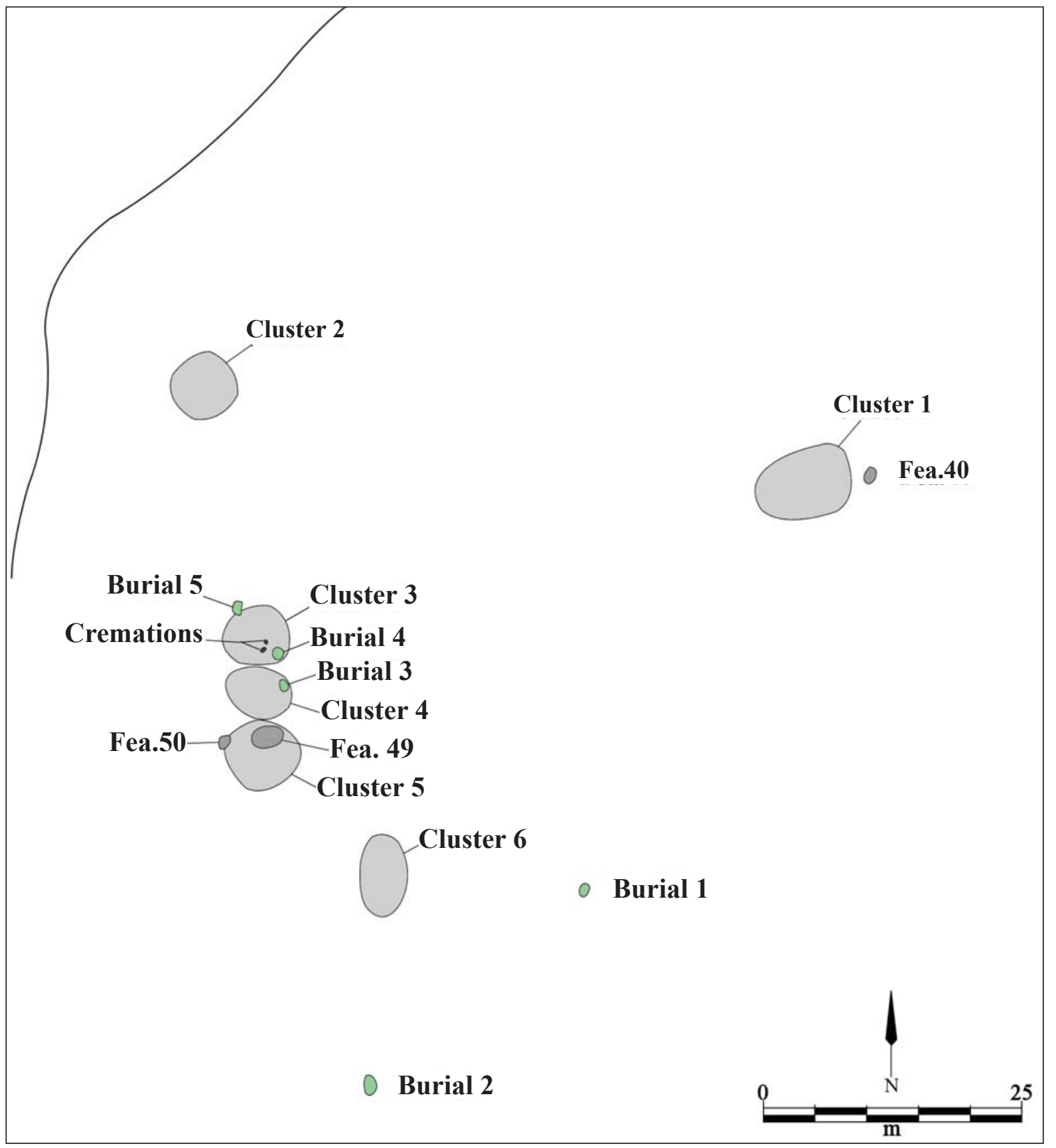

Figure 12. Map of artifact clusters and features at 16SA17.

The burials had single flexed individuals (see Benham et al. 1973:Figure 8a-c) of adult age, none of which had associated funerary offerings; similar flexed burial features were excavated at the Salt Lick site (16SA37a, see McClurkan et al. 1966). The cremations were marked by "charred and burned skeletal material and white ash" (Benham et al. 1973:42). These burial features also had no associated funerary offerings.

Excavations in the habitation deposits at 16SA17 recovered 6,322 plain or decorated sherds (Table 8). About 87 percent of the sherds are from grog-tempered vessels, and sherds from bone-tempered vessels account for the remaining 13 percent of the assemblage; the highest proportion of bone-tempered sherds occurs in the fine wares (19.7 percent). 
Table 8. Ceramic sherd assemblage from 16SA17.

\begin{tabular}{lccc}
\hline Ware & Grog-tempered & Bone-tempered & N \\
\hline Plain & 29 & 6 & 35 \\
Utility & 2465 & 358 & 2823 \\
Fine & 65 & 16 & 81 \\
Totals & 2559 & 380 & 2939 \\
\hline
\end{tabular}

Note: this does not include the 3383 plain body and base sherds that were not subject to temper analysis

More than 97 percent of the decorated sherds $(n=2,904)$ are from utility wares (see Table 8); fine ware sherds are scarce ( 2.8 percent) in the assemblage. The plain to decorated sherd ratio is 1.18.

A wide variety of decorative methods and elements are represented in the sherds from utility ware vessels at 16SA17 (Table 9). The most common decorations in the assemblage are incised lines of different elements; sherds from incised vessels comprise 59 percent of the utility ware sherds and 57 percent of all the utility ware rim sherds. Other common decorative methods include punctated (13 percent of the utility ware sherds and 6.6 percent of the utility ware rim sherds), brushed (11.4 percent of the utility ware sherds and 9.6 percent of the utility ware rims), and incised-punctated (10.8 percent of the utility ware sherds but 22.5 percent of the utility ware rim sherds).

Table 9. Decorative methods and elements in the utility ware sherds from 16SA17.

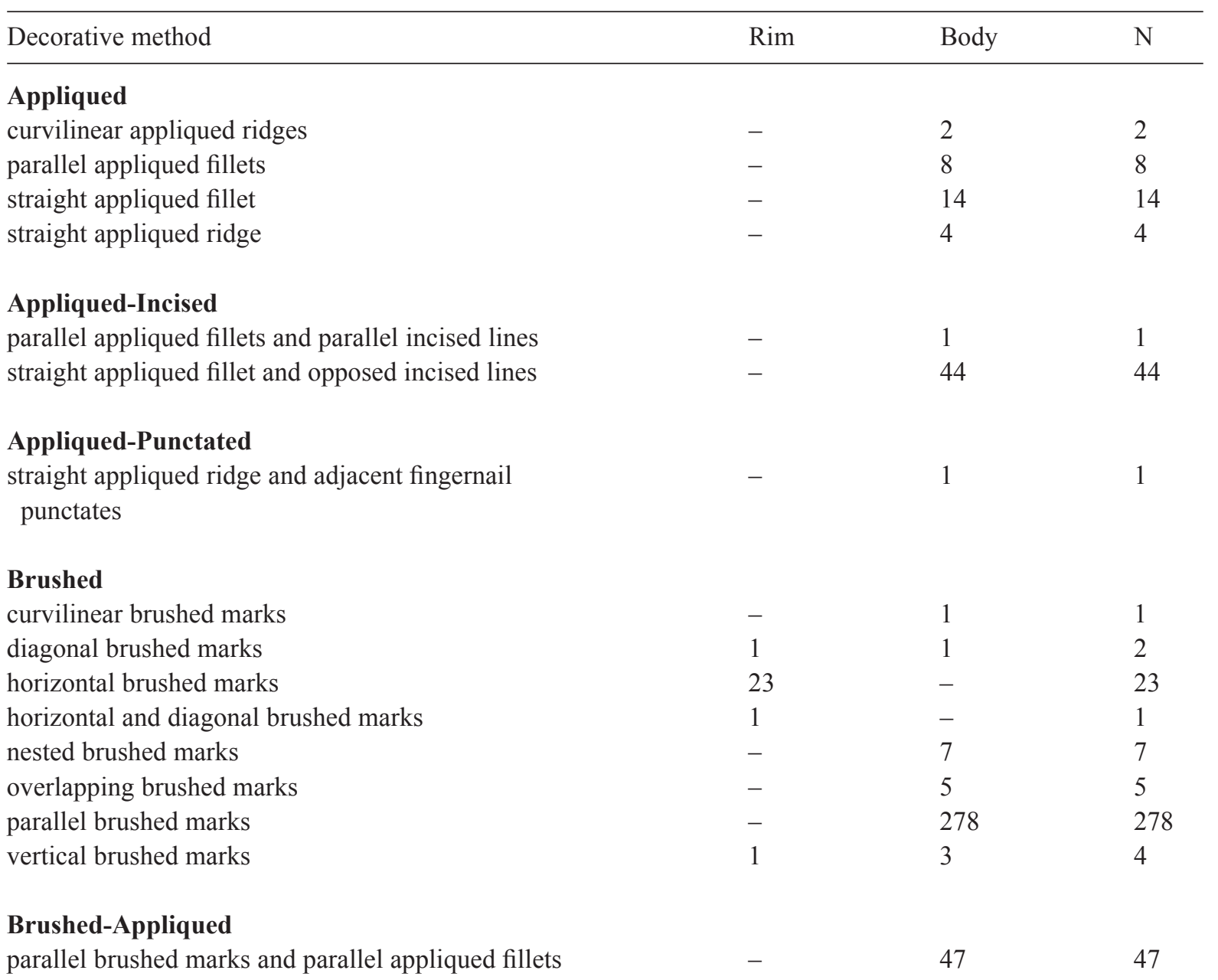


Table 9. Decorative methods and elements in the utility ware sherds from 16SA17, cont.

\begin{tabular}{|c|c|c|c|}
\hline Decorative method & Rim & Body & $\mathrm{N}$ \\
\hline \multicolumn{4}{|l|}{ Brushed-Incised } \\
\hline $\begin{array}{l}\text { horizontal brushed marks and overlying diagonal } \\
\text { lines }\end{array}$ & 1 & - & 1 \\
\hline \multicolumn{4}{|l|}{ Brushed-Punctated } \\
\hline $\begin{array}{l}\text { diagonal brushed marks and vertical tool punctated } \\
\text { row }\end{array}$ & - & 1 & 1 \\
\hline $\begin{array}{l}\text { horizontal brushed marks and tool punctated row under } \\
\text { the lip }\end{array}$ & 3 & - & 3 \\
\hline $\begin{array}{l}\text { horizontal brushed marks and tool punctates at the } \\
\text { edge of the lip }\end{array}$ & 3 & - & 3 \\
\hline $\begin{array}{l}\text { horizontal brushed marks and adjacent tool punctated } \\
\text { row }\end{array}$ & - & 5 & 5 \\
\hline vertical brushing marks and fingernail punctated row & - & 1 & 1 \\
\hline \multicolumn{4}{|l|}{ Grooved } \\
\hline horizontal grooved & 1 & - & 1 \\
\hline parallel grooved & - & 1 & 1 \\
\hline \multicolumn{4}{|l|}{ Incised } \\
\hline cross-hatched lines & 4 & 20 & 24 \\
\hline curvilinear lines & - & 7 & 7 \\
\hline diagonal lines & 32 & 7 & 39 \\
\hline diagonal opposed lines & 3 & 90 & 93 \\
\hline horizontal lines & 88 & - & 88 \\
\hline horizontal and diagonal lines & 15 & 24 & 39 \\
\hline horizontal and vertical lines & 1 & 17 & 18 \\
\hline nested incised triangles filled with incised lines & - & 2 & 2 \\
\hline opposed lines & - & 125 & 125 \\
\hline parallel lines & - & 1066 & 1066 \\
\hline straight line & - & 128 & 128 \\
\hline vertical lines & 12 & 3 & 15 \\
\hline vertical line and diagonal opposed lines & - & 17 & 17 \\
\hline \multicolumn{4}{|l|}{ Incised-Punctated } \\
\hline $\begin{array}{l}\text { cross-hatched lines (lower rim) and fingernail } \\
\text { punctated rows (body) }\end{array}$ & - & 1 & 1 \\
\hline $\begin{array}{l}\text { curvilinear line and adjacent fingernail punctated } \\
\text { zone }\end{array}$ & - & 1 & 1 \\
\hline curvilinear line and adjacent tool punctated zone & - & 1 & 1 \\
\hline curvilinear incised zones filled with tool punctates & 6 & 7 & 13 \\
\hline diagonal band filled with small tool punctates & 2 & 2 & 4 \\
\hline diagonal panels filled with tool punctates & 1 & - & 1 \\
\hline diagonal line with adjacent tool punctated rows & 1 & - & 1 \\
\hline
\end{tabular}


Table 9. Decorative methods and elements in the utility ware sherds from 16SA17, cont.

\begin{tabular}{|c|c|c|c|}
\hline Decorative method & Rim & Body & $\mathrm{N}$ \\
\hline $\begin{array}{l}\text { diagonal lines with tool punctated rows below lip } \\
\text { and at rim-body juncture }\end{array}$ & 1 & - & 1 \\
\hline $\begin{array}{l}\text { diagonal lines and tool punctated row at rim-- } \\
\text { body juncture }\end{array}$ & - & 1 & 1 \\
\hline $\begin{array}{l}\text { diagonal opposed lines and vertical tool punctated } \\
\text { row }\end{array}$ & - & 14 & 14 \\
\hline $\begin{array}{l}\text { horizontal line and circle; the circle is filled with } \\
\text { circular punctates }\end{array}$ & 1 & - & 1 \\
\hline horizontal lines and circular punctate row & 9 & - & 9 \\
\hline $\begin{array}{l}\text { horizontal line and curvilinear zone filled with tool } \\
\text { punctates; tool punctated row also below lip }\end{array}$ & 1 & - & 1 \\
\hline horizontal line and row of fingernail punctates & 1 & - & 1 \\
\hline $\begin{array}{l}\text { horizontal lines (rim) and fingernail punctated rows } \\
\text { (body) }\end{array}$ & - & 5 & 5 \\
\hline horizontal lines and tool punctated row at lip & 2 & - & 2 \\
\hline horizontal lines between rows of tool punctates & 1 & - & 1 \\
\hline horizontal lines and tool punctated rows & 9 & 5 & 14 \\
\hline $\begin{array}{l}\text { horizontal and diagonal lines and tool punctated } \\
\text { row at lip }\end{array}$ & 2 & - & 2 \\
\hline incised panels filled with fingernail punctates & - & 1 & 1 \\
\hline incised panel/panels filled with tool punctates & - & 69 & 69 \\
\hline opposed lines with adjacent tool punctates & - & 1 & 1 \\
\hline parallel lines between rows of fingernail punctates & - & 5 & 5 \\
\hline parallel lines with adjacent tool punctated rows & - & 13 & 13 \\
\hline parallel lines with tool punctated pendant triangles & - & 1 & 1 \\
\hline parallel lines between rows of tool punctates & - & 1 & 1 \\
\hline straight line with adjacent circular punctated row & - & 2 & 2 \\
\hline straight line with adjacent tool punctated rows & - & 58 & 58 \\
\hline straight line separating tool punctated rows & - & 1 & 1 \\
\hline triangles, filled with circular punctates & 1 & - & 1 \\
\hline $\begin{array}{l}\text { triangles, sets of diagonal incised lines, filled } \\
\text { with tool punctates }\end{array}$ & 21 & 47 & 68 \\
\hline $\begin{array}{l}\text { triangles (upper and lower) filled with tool punctates; } \\
\text { triangles separated by curvilinear incised lines }\end{array}$ & 1 & - & 1 \\
\hline $\begin{array}{l}\text { triangles (upper, middle, and lower) filled with tool } \\
\text { punctations }\end{array}$ & 1 & - & 1 \\
\hline $\begin{array}{l}\text { curvilinear zone filled with tool punctates and } \\
\text { diagonal lines; diagonal lines begin in tool } \\
\text { punctates }\end{array}$ & - & 1 & 1 \\
\hline $\begin{array}{l}\text { diagonal lines and tool punctated row; incised } \\
\text { lines begin in tool punctates }\end{array}$ & - & 5 & 5 \\
\hline
\end{tabular}


Table 9. Decorative methods and elements in the utility ware sherds from 16SA17, cont.

\begin{tabular}{|c|c|c|c|}
\hline Decorative method & Rim & Body & $\mathrm{N}$ \\
\hline $\begin{array}{l}\text { straight line and circular punctated row; incised line } \\
\text { begins in circular punctates }\end{array}$ & - & 1 & 1 \\
\hline \multicolumn{4}{|l|}{ Lip Notched-Incised } \\
\hline lip notched and horizontal lines & 1 & - & 1 \\
\hline lip notched and horizontal-diagonal lines & 2 & - & 2 \\
\hline \multicolumn{4}{|l|}{ Pinched } \\
\hline parallel pinched ridges & - & 6 & 6 \\
\hline \multicolumn{4}{|l|}{ Punctated } \\
\hline circular punctated rows & - & 3 & 3 \\
\hline triangular punctated (circular punctates) zone & 1 & 1 & 2 \\
\hline fingernail punctated panels & 2 & - & 2 \\
\hline fingernail punctated, random arrangement & 2 & 12 & 14 \\
\hline fingernail punctated rows & 1 & 253 & 254 \\
\hline fingernail punctated, single punctate & - & 2 & 2 \\
\hline tool punctated rows & 12 & 74 & 86 \\
\hline tool punctated, single punctate & - & 6 & 6 \\
\hline \multicolumn{4}{|l|}{ Ridged } \\
\hline parallel ridged & - & 15 & 15 \\
\hline vertical ridged & 1 & - & 1 \\
\hline \multicolumn{4}{|l|}{ Ridged-Brushed } \\
\hline parallel ridged and parallel brushed between ridges & - & 6 & 6 \\
\hline Totals & 272 & 2551 & 2823 \\
\hline
\end{tabular}

The range of decorative methods and elements in the 16SA17 decorated sherd assemblage suggest that the site has multiple Caddo components, one primarily dating before ca. A.D. 1200. Both the moderate amount of brushed sherds and the low frequency of Belcher Ridged sherds suggest that the site was then occupied for an unknown length of time between ca. A.D. 1300-1500. A few sherds (most notably a Keno Trailed bowl sherd) hint at limited use of the site in the 17th century as well.

Sherds with appliqued decorative elements comprise 1 percent of the utility wares from the site (see Table 9). These sherds have either straight, parallel, or curvilinear appliqued ridges or fillets (Figure 13a) that likely would have divided the vessel body into panels. Other appliqued sherds ( $n=44,1.6$ percent of the utility ware sherd assemblage) from Pease Brushed-Incised vessels occur in conjunction with either opposed incised lines (Figure 14b) or a zone of fingernail punctates adjacent to the appliqued elements.

The many brushed sherds in the 16SA17 assemblage have horizontal brushing marks on the rim of utility ware jars, and likely also had vertical brushing marks on the vessel body (see Table 9); the orientation of the parallel brushed sherds is not known, although it is suspected that they are predominantly from vertical brushed portions of vessels. Brushed-appliqued body sherds (see Figure 14a) are likely also from the body 


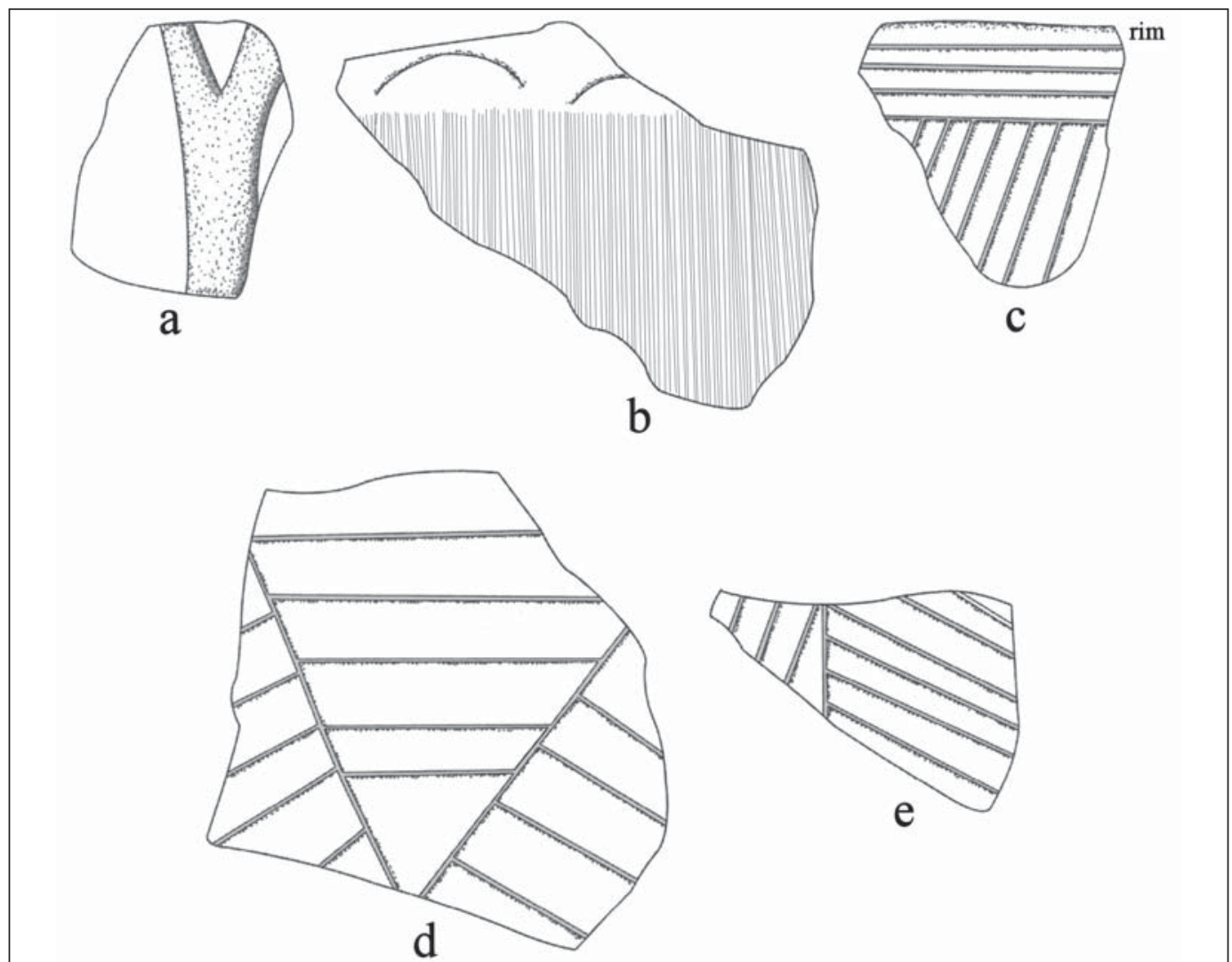

Figure 13. Selective decorative elements in utility ware sherds from 16SA17: a, appliqued ridge; b, Brushed-fingernail punctated; c, Kiam Incised; d, nested incised element; e, Pease Brushed-Incised.

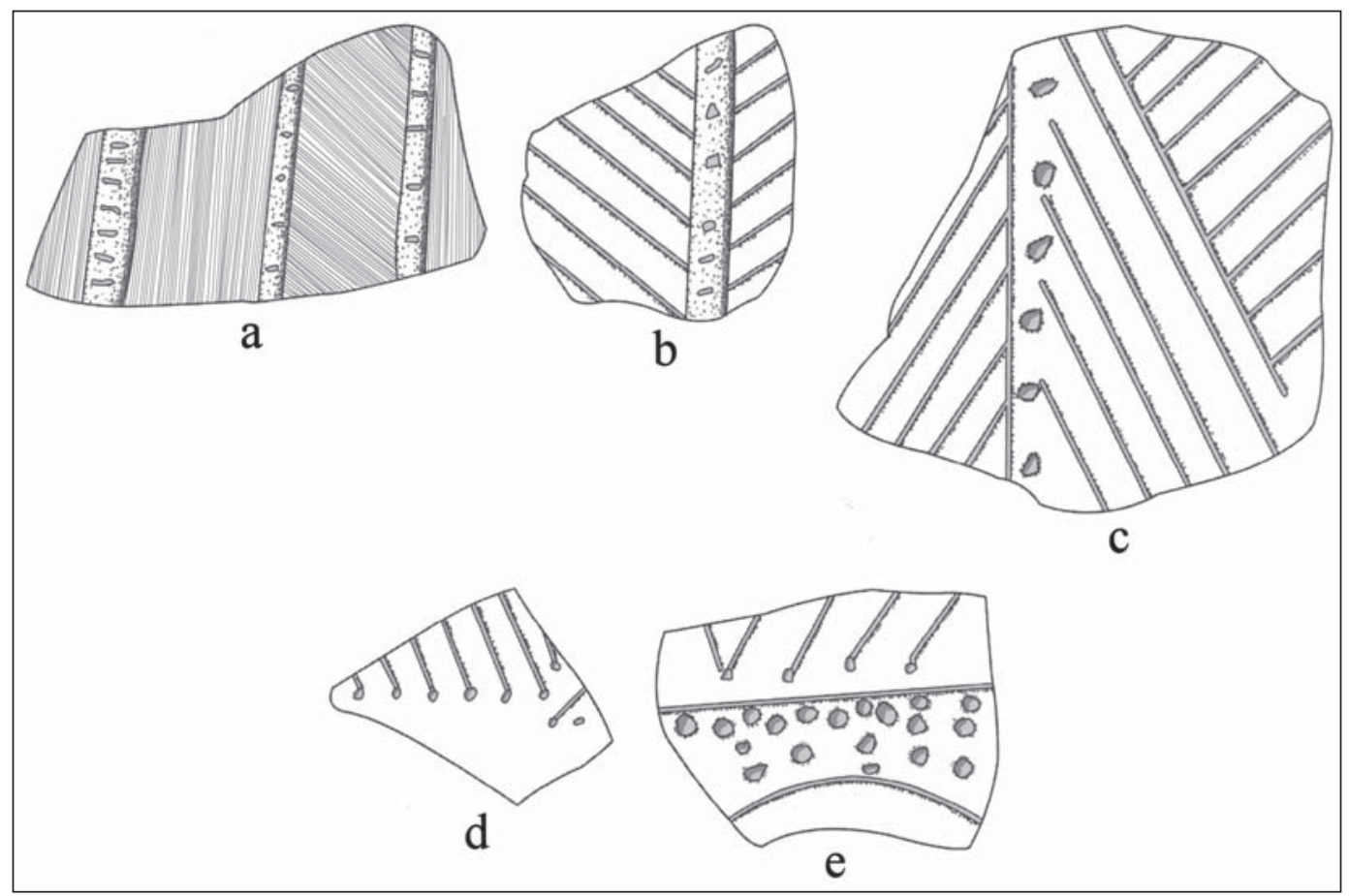

Figure 14. Selected Pease Brushed-Incised and L'Eau Noire Incised sherds in utility wares from 16SA17: a-c, Pease Brushed-Incised; d-e, L'Eau Noire Incised. 
of Pease Brushed-Incised vessels where the body is divided into panels by vertical appliqued elements; the panels were then filled with brushing marks. The brushed-punctated rim sherds have horizontal brushing marks with a row of punctations at the edge or under the vessel lip (see Table 9). One distinctive lower rimbody sherd has a Weches Fingernail Impressed style fingernail punctated row on the rim of a vessel, and vertical brushing marks on the vessel body (see Figure 13b).

The rim and body sherds from incised vessels at the site are dominated by simple geometric decorative elements, including cross-hatched, diagonal, diagonal opposed, horizontal lines, horizontal and diagonal, and vertical (see Figure 13a and Table 9). These are likely from Davis Incised, Dunkin Incised, and Kiam Incised vessels. A number of body sherds from Pease Brushed-Incised vessels in the assemblage have vertical incised lines and diagonal opposed lines (see Figure 13e) on the vessel body. Less than 0.5 percent of the incised sherds from 16SA17 have curvilinear decorative elements. Two body sherds have nested incised triangles (see Figure 13d).

There are two incised rim sherds in the assemblage that have lip notching (see Table 9). Lip notching is a rare decorative treatment in Caddo sherd assemblages from as early as ca. A.D. 900, and continued to be used for decorative purposes as late as the early 18th century. By post-A.D. 1400 times, ceramic assemblages with lip notched vessels occur more regularly in the upper Neches, middle Red River, middle Sabine, and the Angelina River basin (see Perttula 2015a:Figure 9).

A small number of body sherds with incised-punctated decorative elements are from Pease Brushed-Incised vessels. These have panels on the vessel body of diagonal opposed incised lines divided by vertical rows of punctates (see Figure 14c). About 2 percent of the incised-punctated sherds are from L'Eau Noire Incised, var. unspecified vessels (see Figure 14d-e). These have diagonal incised lines that begin in a row of triangular or circular punctates. One of the L'Eau Noire Incised sherds from the site also has a curvilinear zone of circular punctations.

There are a variety of decorative elements in the incised-punctated sherds in the 16SA17 ceramic assemblage (see Table 9). The most common decorative elements in the rim sherds have one or more rows of incised triangles filled with punctations (Figure 15e-h) or sets of horizontal incised lines above one or more rows of circular, fingernail, or tool punctations (Figure 15j). These decorative elements represent more than 74 percent of the incised-punctated rims in the collection. A few rim sherds have diagonal incised bands/ panels filled with punctations (Figure 15d), horizontal and diagonal incised lines above a row of tool punctations, or diagonal incised lines with a row of punctations on either side of the diagonal lines (Figure 15i).

There are also rims with curvilinear incised zones filled with punctations (see Figure 15a-c); perhaps these are from Pineland Punctated-Incised vessels. The Pineland Punctated-Incised type was defined by Jelks (1965:119-122 and Figure 61a-g) from a series of sites at Lake Sam Rayburn in the Neches-Angelina river basins in East Texas. Pineland Punctated-Incised is a grog and/or bone-tempered utility ware, and occurs primarily as beaker-shaped jars as well as ollas and deep bowls. The vessels have concentric, triangular, rectangular, and curvilinear incised zones on the rim filled with tool punctations. Ollas and bowls have design elements on the vessel bodies (see Jelks 1965:Figure 61d, g). Only 6 percent of the incised-punctated rim sherds have curvilinear or circular incised decorative elements filled with punctations.

Several incised-punctated body sherds from 16SA17 may be from pre-A.D. 1200 utility ware vessels. These include sherds from Weches Fingernail Impressed, var. Weches vessels (Figure 16a-b), Kiam Incised and Dunkin Incised vessels with incised lines on the rim and fingernail punctated elements on the vessel body (Figure 16f-g), and band punctated sherds (Figure 16c) with rows of punctations between the incised lines. This decorative element is noted in ceramic assemblages at Early Caddo period sites in East Texas and Northwest Louisiana (Perttula 2013:186 and Figure 4b).

Other main decorative elements in the incised-punctated body sherds from the site have incised panels filled with punctations; parallel and straight incised lines adjacent to one or more rows of punctations; and 


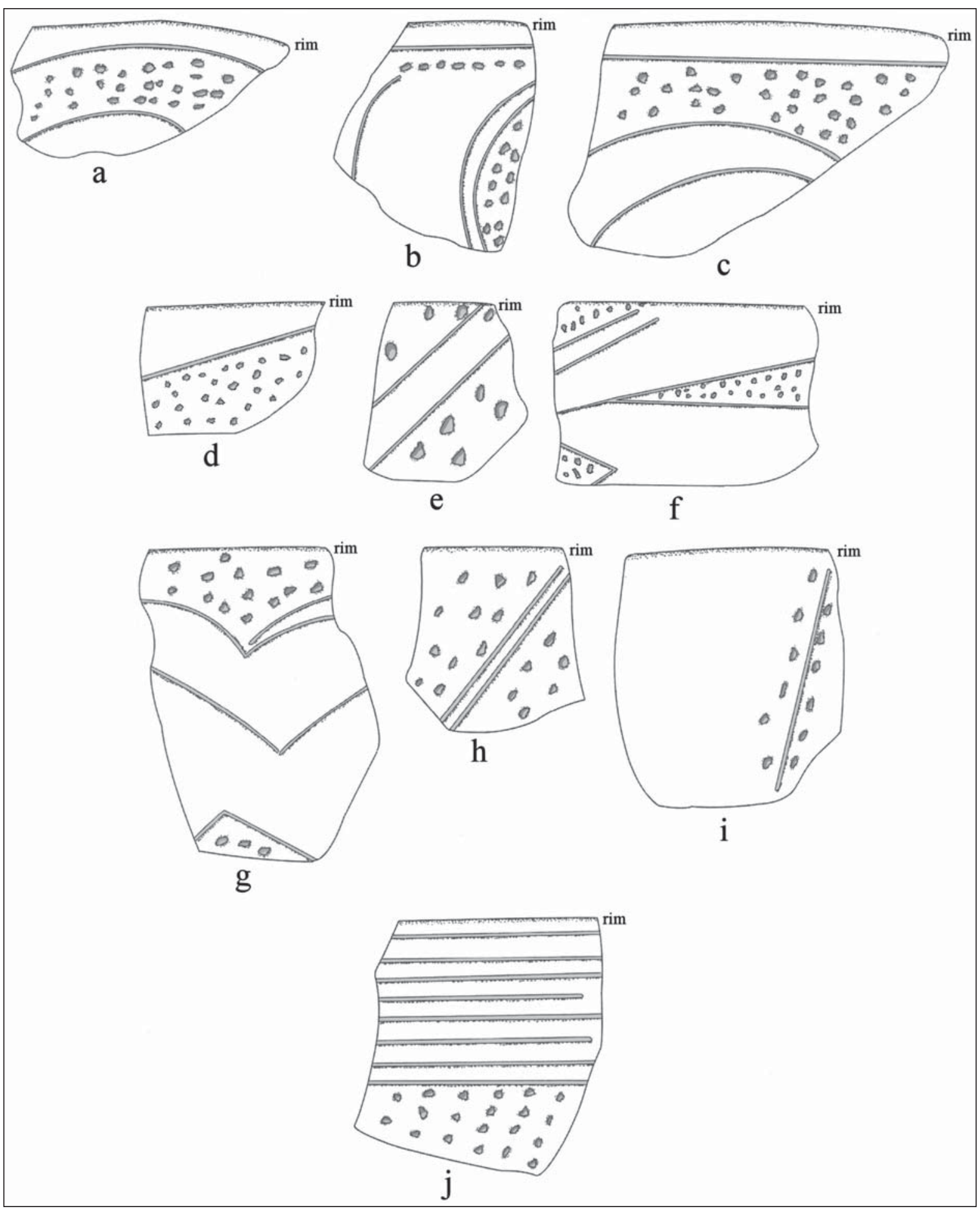

Figure 15. Selected incised-punctated decorative elements in utility ware rim sherds from 16SA17. 


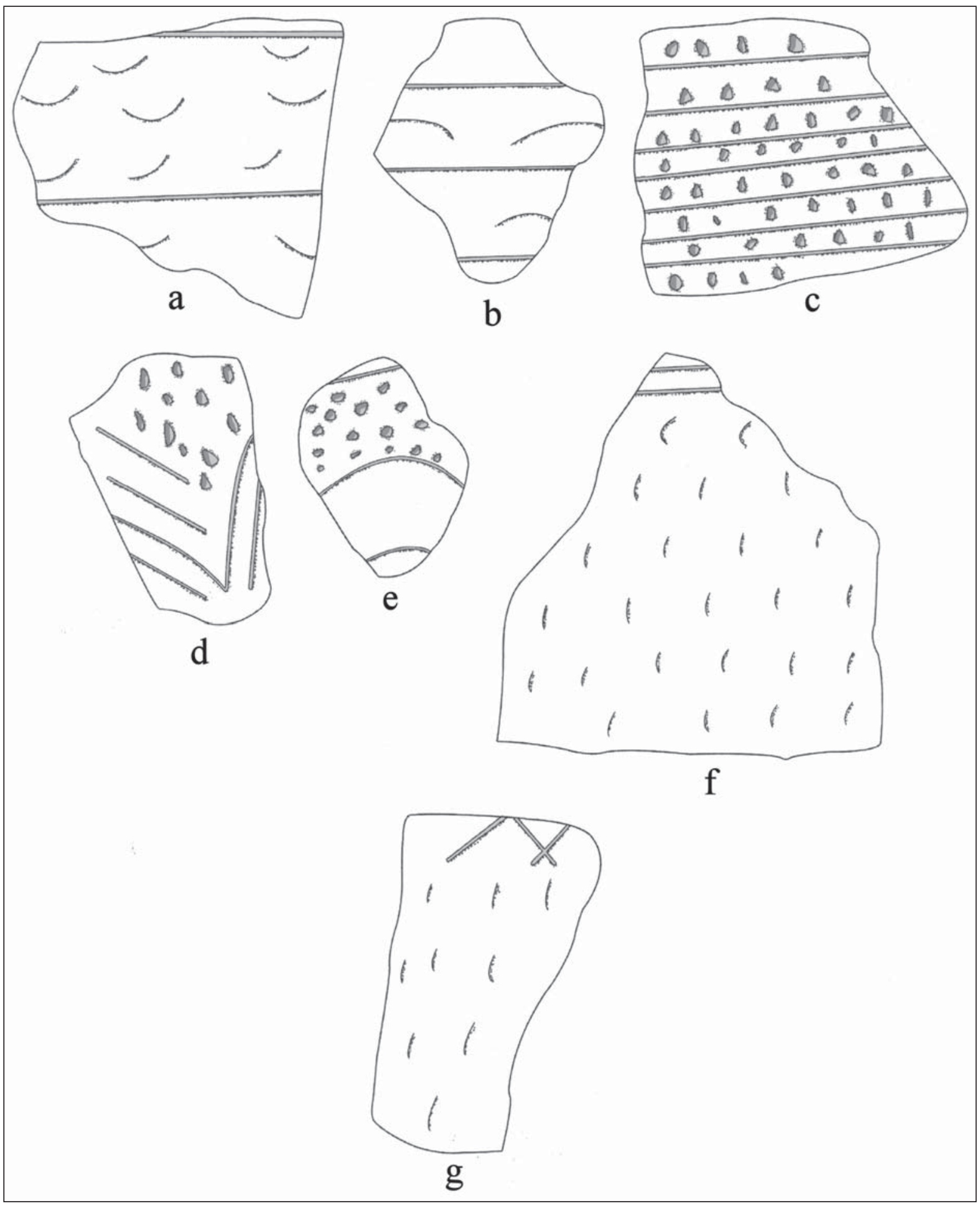

Figure 16. Selected incised-punctated decorative elements in utility ware body sherds from 16SA17. 
incised triangles filled with punctations (see Figure 16d). Only a few incised-punctated sherds ( 3 percent of the incised-punctated sherds) have curvilinear incised zones filled with punctations (see Figure 16e).

The punctated sherds in the 16SA17 utility ware assemblage predominantly have fingernail punctated elements ( 74 percent of the punctated sherds, see Table 9 ), followed by tool punctated elements ( 25 percent) and circular punctated elements (1 percent). These punctations tend to occur in horizontal or vertical rows, with only a few sherds with zones or panels filled with punctations.

Less than 1 percent of the utility ware sherds from the site are from Belcher Ridged vessels (see Table 9). These do include both var. Belcher (parallel or vertical ridges only) and var. Byram Ferry (parallel ridges with parallel brushing marks between the ridges) vessel sherds. The occurrence of these varieties of Belcher Ridged at the site indicates that it was occupied beginning after ca. A.D. 1400, and then that occupation continued into the 16th century (if not later, given certain fine ware sherds found at 16SA17).

The fine ware sherds from 16SA17 are from vessels with engraved ( $=78,96$ percent of the fine ware sherds in the assemblage), red-slipped ( $n=2,2.5$ percent), and trailed ( $n=1,1.2$ percent) (Table 10). The fine ware rim sherds $(n=23)$ represent 7.8 percent of all the decorated rim sherds from the site, indicating the overall predominance of utility ware vessels at the site.

Table 10. Decorative methods and elements in the fine ware sherds from 16SA17.

\begin{tabular}{|c|c|c|c|}
\hline Decorative method & $\operatorname{Rim}$ & Body & $\mathrm{N}$ \\
\hline \multicolumn{4}{|l|}{ Engraved } \\
\hline circle and inner diamond el. & 1 & - & 1 \\
\hline cross-hatched lines & - & 1 & 1 \\
\hline $\begin{array}{l}\text { curvilinear cross-hatched zone, negative ovals, and } \\
\text { straight line with tick marks }\end{array}$ & - & 1 & 1 \\
\hline $\begin{array}{l}\text { cross-hatched zones, semi-circular, diagonal, and } \\
\text { triangular }\end{array}$ & 1 & - & 1 \\
\hline cross-hatched zone, diagonal & 1 & - & 1 \\
\hline cross-hatched zone, horizontal & 2 & 1 & 3 \\
\hline cross-hatched zones, narrow & - & 7 & 7 \\
\hline cross-hatched triangle el. & - & 1 & 1 \\
\hline curvilinear lines & - & 9 & 9 \\
\hline curvilinear hatched zones & - & 5 & 5 \\
\hline diagonal lines & 4 & - & 4 \\
\hline $\begin{array}{l}\text { diagonal cross-hatched zone and diagonal line } \\
\text { with tick marks }\end{array}$ & - & 1 & 1 \\
\hline diagonal hatched panel & - & 1 & 1 \\
\hline diagonal opposed lines & 1 & - & 1 \\
\hline horizontal line/lines & 4 & 3 & 7 \\
\hline horizontal line and excised pendant triangles & - & 2 & 2 \\
\hline horizontal and curvilinear lines, with tick marks & - & 2 & 2 \\
\hline horizontal, curvilinear, and diagonal lines & 1 & - & 1 \\
\hline horizontal-diagonal lines & 2 & - & 2 \\
\hline
\end{tabular}


Table 10. Decorative methods and elements in the fine ware sherds from 16SA17, cont.

\begin{tabular}{|c|c|c|c|}
\hline Decorative method & Rim & Body & $\mathrm{N}$ \\
\hline horizontal and diagonal opposed lines & 1 & - & 1 \\
\hline horizontal-vertical lines & 1 & - & 1 \\
\hline horizontal-vertical-and diagonal lines & - & 1 & 1 \\
\hline horizontal line and horizontal cross-hatched zone & 1 & - & 1 \\
\hline horizontal hatched zones & - & 11 & 11 \\
\hline horizontal and diagonal hatched panels & 1 & - & 1 \\
\hline horizontal and vertical hatched zones & - & 1 & 1 \\
\hline opposed lines & - & 2 & 2 \\
\hline parallel lines & - & 3 & 3 \\
\hline rectilinear el. & - & 1 & 1 \\
\hline rectilinear panel and hatched diagonal zone & - & 1 & 1 \\
\hline scroll fill zone & - & 1 & 1 \\
\hline straight line & - & 1 & 1 \\
\hline vertical line and opposed curvilinear lines & 1 & - & 1 \\
\hline \multicolumn{4}{|l|}{ Red-Slipped } \\
\hline ext. red-slipped & - & 2 & 2 \\
\hline \multicolumn{4}{|l|}{ Trailed } \\
\hline curvilinear trailed line & 1 & - & 1 \\
\hline Totals & 23 & 58 & 81 \\
\hline
\end{tabular}

Almost half of the engraved rims have horizontal line elements, either as the sole element or in association with curvilinear, diagonal, diagonal opposed, or vertical lines, as well as hatched and cross-hatched zones and panels (Figure 17a-c, h; see Table 10). Other rim sherds have diagonal or diagonal opposed lines or simply cross-hatched zones with different orientations (Figure 17i). One rim has a Ripley Engraved circle and diamond motif (Figure 17g), as seen on Ripley Engraved, var. McKinney vessels.

Body sherds from engraved vessels have for the most part the same range of decorative elements as the rims, including horizontal and vertical hatched zones, sets of horizontal, curvilinear, or vertical lines, and cross-hatched zones (see Figure 17d-f). One carinated bowl sherd has a row of cross-hatched triangle elements (see Figure 17j), and several others have ticked lines in association with cross-hatched zones (see Figure 17k-1) or hooked arm curvilinear lines (see Figure 17m); these latter sherds may be from Glassell Engraved carinated bowls.

The few red-slipped sherds are from grog-tempered vessels. The one rim sherd with a trailed decorative element is from a Keno Trailed bowl tempered with bone.

In addition to the many ceramic vessel sherds, there are three ceramic pipe sherds from the excavations at 16SA17. Two are grog-tempered pipe bowls from long-stemmed Red River pipes; the pipe bowls have direct rims and rounded or flat lips, and the bowls are 5.2-6.2 $\mathrm{mm}$ in thickness. The third pipe sherd is the stem to a grog-tempered platform pipe. The stem is $32.0 \mathrm{~mm}$ in orifice diameter, and the stem opening is $9.0 \mathrm{~cm}$ in diameter; the stem is $7.3 \mathrm{~mm}$ thick. 


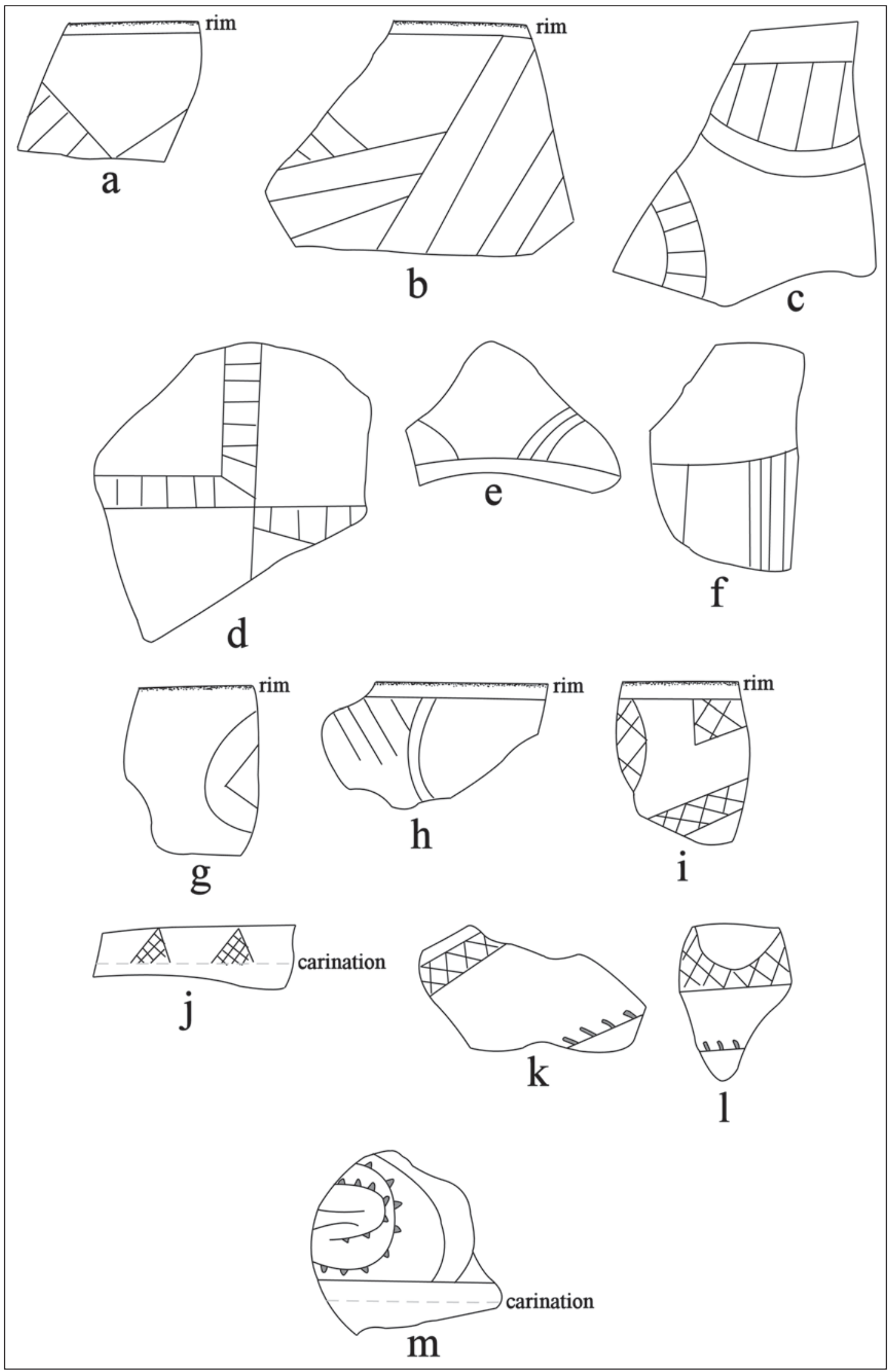

Figure 17. Selected engraved decorative elements in fine ware sherds from 16SA17. 
Arrow points, arrow point preforms, and fragments are abundant at the site (Table 12); arrow point preforms comprise 48 percent of the recovered arrow points. Except for one fragment of gray novaculite, the other arrow points are made from local earth-toned cherts. Brown and red cherts were the preferred raw materials for arrow point manufacture: these two materials account for 41 percent and 38 percent, respectively, of the arrow points from 16SA17.

Table 12. Arrow points from 16SA17.

\begin{tabular}{lllllll}
\hline Kind & $\begin{array}{l}\text { brown } \\
\text { chert }\end{array}$ & $\begin{array}{l}\text { red } \\
\text { chert }\end{array}$ & $\begin{array}{l}\text { yellow } \\
\text { chert }\end{array}$ & $\begin{array}{l}\text { reddish- } \\
\text { brown } \\
\text { chert }\end{array}$ & gNOV & N \\
\hline fragments & 4 & 7 & 1 & 1 & 1 & 14 \\
preforms & 12 & 10 & 3 & 3 & - & 28 \\
Perdiz & 4 & 1 & 1 & 1 & - & 7 \\
Alba & 4 & 4 & - & - & - & 9 \\
\hline Totals & 24 & 22 & 5 & 6 & 1 & 58 \\
\hline
\end{tabular}

gNOV=gray novaculite

\section{$16 \mathrm{SA20}$}

Archaeological collections from 16SA20 were obtained during archaeological investigations by both Scurlock and Davis (1962) and Scurlock (1964). The survey work by UT in 1962 located the site on a ca. 90 x $45 \mathrm{~m}$ long and wide sandy ridge (Scurlock and Davis 1962:46). The UT 1962-1963 test excavations consisted of "a few test pits" (Scurlock 1964:23), and the site had been much damaged by pothunters and the rooting of hogs. The test pits indicated that the archaeological deposits consisted of a "rather shallow, tan sand overlying a sterile red clay."

Only a small sample of Caddo ceramic sherds were recovered in the survey and test excavations at 16SA20 (Table 13). The sherds are primarily from grog-tempered vessels (86 percent). The low plain to decorated sherd ratio (1.12) and the high proportion of sherds with brushing decorative elements among all the decorated sherds (53 percent) suggests that 16SA20 was occupied after ca. A.D. 1400, during the Late Caddo period.

Table 13. Ceramic sherds from 16SA20.

\begin{tabular}{llccc}
\hline Ware & & grog-tempered & bone-tempered & N \\
\hline Plain & & 16 & 3 & 19 \\
Utility & & 5 & 2 & 7 \\
& Brushed & 1 & - & 1 \\
& Brushed-Appliqued & 1 & - & 1 \\
& Brushed-Incised & 5 & - & 5 \\
& Incised & 1 & - & 1 \\
& Incised-Punctated & & - & 2 \\
Fine & Engraved & 2 & 5 & 36 \\
\hline Totals & & 31 &
\end{tabular}




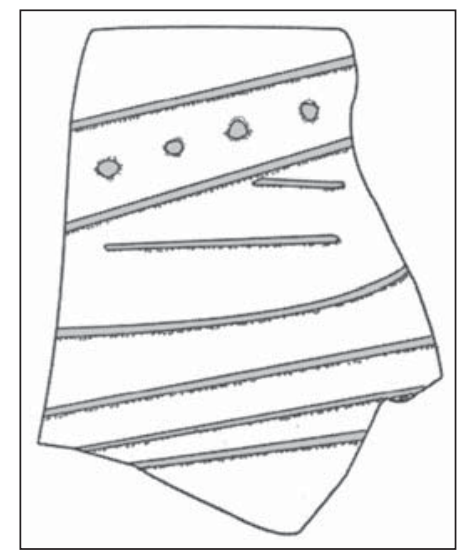

Figure 18. Incised-punctated body sherd from 16SA20.

The brushed sherds have horizontal brushing marks on the rim and parallel (i.e., vertical in orientation) brushing on the body. One possible Pease Brushed-Incised sherd has parallel appliqued fillets with parallel brushing between the fillets. Another utility ware sherd has parallel brushing marks with overlying curvilinear incised lines cut through the brushing. The incised body sherds from the site have parallel $(n=3)$, straight $(\mathrm{n}=1)$ and diagonal opposed $(\mathrm{n}=1)$ decorative elements. The one incised-punctated body sherd has a diagonal incised panel filled with a row of small circular punctations (Figure 18). Outside the incised panel are a series of horizontal incised lines.

The fine ware sherds comprise 11.8 percent of the decorated sherds from the site (see Table 13). One has opposed engraved lines, while the other has a straight engraved line with small open pendant triangles.

\section{Horatio Kunaz Site (16SA27)}

The Horatio Kunaz site was located by Scurlock and Davis (1962:49) on a sandy ridge on the south side of La Nana Bayou, and was estimated to be about 1 acre in extent. It appeared to have deep archaeological deposits with possible preserved areas of midden. UT excavations in 1963 identified deposits between ca. 45-76 cm in thickness with midden-stained sandy sediments (Scurlock 1964:24).

SMU conducted excavations at the site during the 1966-1967 season at Toledo Bend Reservoir (Jensen 1968b). The work consisted of the excavation of eight backhoe trenches and four 1 x 4 m "strati-tests." The archaeological deposits were different between the northern and southern parts of the landform. In the northern area the deposits were sands that were $25-45 \mathrm{~cm}$ in thickness overlying a orange-red clay subsoil (Jensen 1968b:61-62). By contrast, the archaeological deposits in the southern part of the Horatio Kunaz had deep sand A- and E-horizons that ranged from 55-165 cm in depth, with a buried midden deposit (black sand) that varied from $15 \mathrm{~cm}$ thick to "almost a meter in depth" (Jensen 1968b:62). According to Jensen (1968b:63), "no profiles or site maps were made [by SMU] because of time limitations."

The ceramic sherd assemblage from the Horatio Kunaz site is dominated by sherds from grog-tempered vessels; more than 87 percent of the sherds in the assemblage are from grog-tempered vessels (Table 14). Sherds from bone-tempered vessels represent approximately 12.6 percent of the site's ceramic assemblage. The highest proportion of sherds from bone-tempered vessels is in the fine wares (24.1 percent), almost double the proportion of the assemblage as a whole. 
Table 14. Ceramic sherd assemblage from the Horatio Kunaz site (16SA27).

\begin{tabular}{lccc}
\hline Ware & Grog-tempered & Bone-tempered & N \\
\hline Plain & 441 & 57 & 498 \\
Utility & 302 & 46 & 348 \\
Fine & 22 & 7 & 29 \\
\hline Totals & 765 & 110 & 875 \\
\hline
\end{tabular}

One of the plain sherds may be from a vessel appendage (i.e., part of a tab tail or lip node), perhaps from an effigy vessel. The decorated sherd assemblage from the site is primarily comprised of sherds from utility ware vessels ( 92.7 percent); 93.3 percent of the rim sherds are also from utility ware vessels. About 53 percent of the utility ware sherds (and 57 percent of the utility ware rim sherds) are from vessels with incised decorative elements (Table 15). Another 18 percent of the decorated sherds (and 30.4 percent of the utility ware rim sherds) are from vessels with incised-punctated decorative elements, and sherds with brushing marks comprise 15.3 percent of the utility ware sherds (including 7 percent of the utility ware rim sherds); an additional 2.9 percent of the utility ware sherds have brushed marks in combination with either appliqued or incised decorative elements (Table 15). The remainder of the decorated sherds from utility ware vessels are either punctated (4.6 percent); appliqued-incised (3.2 percent); ridged ( 0.9 percent); ridgedbrushed $(0.6$ percent $)$; appliqued ( 0.6 percent $)$; and pinched $(0.3$ percent $)$.

Table 15. Decorative methods and elements in the utility ware sherds from the Horatio Kunaz site (16SA27).

Decorative method

Rim Body N

Appliqued

parallel appliqued fillets

straight appliqued ridge

$\begin{array}{lll}- & 1 & 1 \\ - & 1 & 1 \\ & & \\ - & 1 & 1 \\ - & & \\ - & 4 & 5 \\ - & 5 & 1\end{array}$

Appliqued-Incised

parallel appliqued fillets and diagonal opposed lines between fillets straight appliqued fillet and diagonal incised panel straight appliqued fillet and diagonal opposed lines straight appliqued ridge and straight incised line

\section{Brushed}

diagonal brushed marks

horizontal brushed marks

overlapping brushed marks

parallel brushed marks

vertical brushed

$\begin{array}{lll}1 & - & 1 \\ 1 & - & 1 \\ - & 1 & 1 \\ - & 48 & 48 \\ 2 & - & 2\end{array}$

\section{Brushed-Appliqued}

parallel brushed marks and parallel appliqued fillets

parallel brushed marks and straight appliqued fillet

$\begin{array}{lll}- & 2 & 2 \\ - & 4\end{array}$

\section{Brushed-Incised}

horizontal brushed marks and short vertical incised lines under lip and above brushing 
Table 15. Decorative methods and elements in the utility ware sherds from the Horatio Kunaz site (16SA27), cont.

\begin{tabular}{llll}
\hline Decorative method & Rim & Body & N \\
\hline parallel brushed-incised marks and lines & - & 3 & 3 \\
Incised & & & \\
cross-hatched lines & - & 3 & 3 \\
curvilinear lines & - & 1 & 1 \\
diagonal lines & 4 & 1 & 5 \\
diagonal opposed lines & 2 & 14 & 16 \\
diagonal opposed lines and hatched nested triangle & 1 & - & 1 \\
diagonal opposed lines and vertical lines & 1 & - & 1 \\
horizontal lines & 15 & - & 15 \\
horizontal lines and nested triangle & 1 & - & 1 \\
horizontal and diagonal lines & 6 & 1 & 7 \\
horizontal and vertical lines & 1 & 1 & 2 \\
opposed lines & - & 7 & 7 \\
parallel lines & - & 114 & 114 \\
straight line & - & 4 & 4 \\
vertical lines & - & 5 & 4 \\
vertical incised panels filled with diagonal opposed & 1 & 3 &
\end{tabular}

\section{Incised-Punctated}

circular incised zones filled with circular punctates circular incised zone filled with tool punctates

$-$

$-$

diagonal panels filled with tool punctates

diagonal lines and diagonal panels filled with circular punctates

diagonal lines above horizontal row of tool punctates diagonal lines and vertical rows of tool punctates diagonal incised triangles filled with circular punctates diagonal incised triangles filled with tool punctates diagonal opposed lines and triangular zone filled with tool punctates on the rim; diagonal incised panels on body filled with tool punctates

horizontal panels filled with circular punctates horizontal panel with diagonal hatched lines above zone with tool punctated rows

horizontal lines above tool punctated rows horizontal and diagonal lines and triangular zone filled with circular punctates

horizontal and diagonal lines and triangular zone filled with tool punctates horizontal, diagonal, and vertical lines and triangular zone with tool punctates

$-$

-

$-$ 
Table 15. Decorative methods and elements in the utility ware sherds from the Horatio Kunaz site (16SA27), cont.

\begin{tabular}{|c|c|c|c|}
\hline Decorative method & $\operatorname{Rim}$ & Body & $\mathrm{N}$ \\
\hline $\begin{array}{l}\text { horizontal and diagonal lines and tool punctated row } \\
\text { at rim-body juncture }\end{array}$ & 1 & - & 1 \\
\hline $\begin{array}{l}\text { horizontal and vertical lines and rows of tool punctates } \\
\text { on either side of a horizontal line }\end{array}$ & - & 1 & 1 \\
\hline parallel incised bands filled with tool punctates & - & 2 & 2 \\
\hline parallel lines adjacent to circular punctated row & - & 2 & 2 \\
\hline parallel lines between rows of tool punctates & - & 1 & 1 \\
\hline parallel lines adjacent to opposed rows of tool punctates & - & 1 & 1 \\
\hline straight line and adjacent circular punctated row & - & 3 & 3 \\
\hline straight line and adjacent tool punctated row & - & 7 & 7 \\
\hline $\begin{array}{l}\text { vertical lines divided by vertical row of circular } \\
\text { punctates }\end{array}$ & 1 & - & 1 \\
\hline $\begin{array}{l}\text { curvilinear and rectilinear panels; one incised line in } \\
\text { interior panel begins in triangular tool punctation }\end{array}$ & - & 4 & 4 \\
\hline diagonal lines; lines begin in triangular tool punctate & - & 1 & 1 \\
\hline $\begin{array}{l}\text { diagonal and horizontal lines; diagonal lines begin in } \\
\text { triangular tool punctations }\end{array}$ & - & 4 & 4 \\
\hline $\begin{array}{l}\text { diagonal opposed lines; one row of lines begins in } \\
\text { triangular tool punctations }\end{array}$ & - & 2 & 2 \\
\hline Subtotal, Incised-Punctated & 17 & 47 & 64 \\
\hline \multicolumn{4}{|l|}{ Pinched } \\
\hline parallel pinched ridges & - & 1 & 1 \\
\hline \multicolumn{4}{|l|}{ Punctated } \\
\hline circular punctated rows & 1 & 2 & 3 \\
\hline fingernail punctated rows & 1 & 4 & 5 \\
\hline tool punctated rows & - & 8 & 8 \\
\hline \multicolumn{4}{|l|}{ Ridged } \\
\hline parallel ridged & - & 3 & 3 \\
\hline $\begin{array}{l}\text { Ridged-Brushed } \\
\text { parallel ridged and parallel brushed marks between } \\
\text { ridges }\end{array}$ & - & 2 & 2 \\
\hline Totals & 56 & 292 & 348 \\
\hline
\end{tabular}

The range of types and decorative elements represented in the Horatio Kunaz ceramic assemblage suggests that it was occupied by Caddo peoples at several different times both before and after ca. A.D. 1200, and as late as after ca. A.D. 1600. The prevalence of sherds from vessels with incised and incised-punctated decorative elements suggests that the principal occupation at the site took place before ca. A.D. 1350 . 
The few appliqued sherds have parallel or straight appliqued fillet or appliqued ridge elements (see Table 15). These elements would likely have divided the vessel body into quadrants, and in these cases the area between the appliqued fillets/ridges were left plain rather than decorated with brushing marks or incised elements. The appliqued-incised (Figure 19g-h) and brushed-appliqued sherds (together comprising 17 body sherds, 4.9 percent of the utility ware sherds) from the Horatio Kunaz site are from several Pease Brushed-Incised jars (see Suhm and Jelks 1962:Plate 60), as are several incised body sherds (see below).

Rim sherds with brushed marks have horizontal, diagonal, and vertical brushing decorative elements (see Table 15). Almost all of the body sherds with brushing marks have parallel brushing, suggesting that some utility ware jars likely had vertical brushing on their bodies. The few brushed-incised body sherds have parallel brushed marks and adjacent parallel incised lines (see Table 15), while one rim has horizontal brushing below a zone of short vertical incised lines below the vessel lip (see Figure 19j).

The many sherds from vessels decorated with incised elements feature rims with horizontal lines, horizontal and diagonal lines, and diagonal lines (see Figure 19b, d), as well as rims with diagonal opposed lines (see Figure 19a, c). Most of these rims are from Dunkin Incised, Davis Incised, or Kiam Incised vessels. Distinctive incised rim and body sherds with vertical incised panels filled with diagonal opposed lines (see Figure 19e-f) are from an early variety of Pease Brushed-Incised (see Suhm and Jelks 1962:Plate 60k). Body sherds are dominated by geometric incised elements, including diagonal, diagonal opposed, vertical, and cross-hatched lines (see Table 15).

The sherds from incised-punctated vessels are a stylistically diverse lot. Many of the rims have horizontal and diagonal incised lines that form triangular zones filled with either circular or tool punctates (Figure 20c; see also Table 15). Others have incised panels (diagonal or horizontal) filled with punctates of various kinds (Figure 20b, d-f). One rim has vertical incised lines divided by a row of tool punctations (Figure 20a).

Body sherds from incised-punctated vessels have a similar range of decorative elements as the rims (Figure 21), with triangular incised zones filled with punctations (Figure 21c-d, f-g) and panels filled with punctations and/or diagonal incised lines (Figure 21h-j). The decorations on several of the sherds indicate that both the rim and the body of some vessels had incised-punctated decorative elements, including diagonal panels filled with punctations (Figure 21a) or diagonal incised lines on vessel bodies (Figure 21d). Less than 5 percent of the incised-punctated sherds have circular incised elements filled with punctations (Figure 21e).

About 17 percent of the incised-punctated sherds are from L'Eau Incised, var. L'Eau Noire body sherds (Figure 22; see Table 15). These sherds have horizontal and curvilinear panels and diagonal opposed incised lines, and each of the sherds from this type at the Horatio Kunaz site have at least one incised line that begins in a triangular tool punctation. Brown (1998:57) indicates that this utility ware was made in the Lower Mississippi River valley between ca. A.D. 1200-1350. 


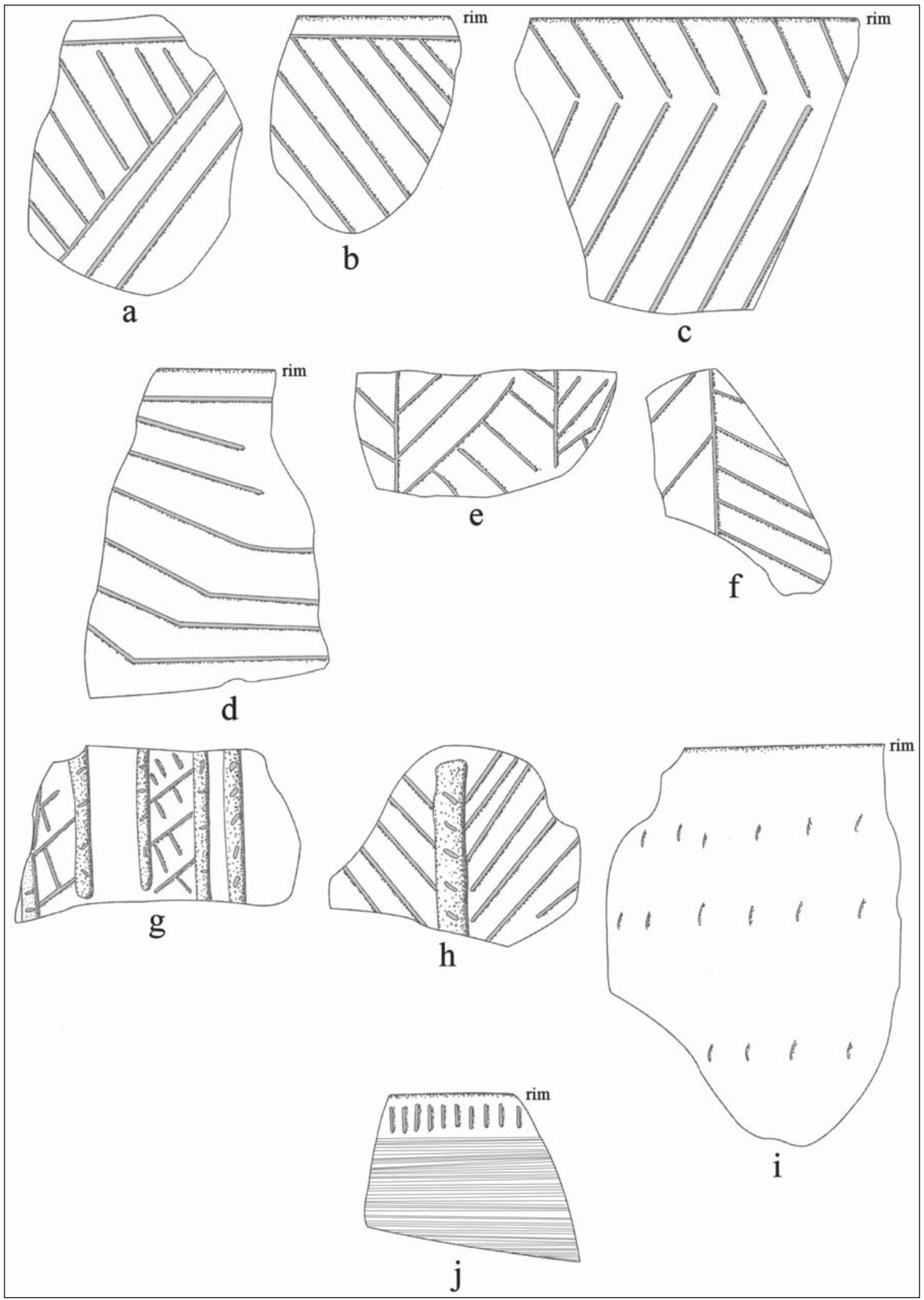

Figure 19. Selected decorative elements on appliqued-incised, brushed-incised, incised, and punctated utility ware sherds from the Horatio Kunaz site: a-d, incised rim sherds; e-f, Pease Brushed-Incised body sherds; g-h, incised-appliqued body sherds; i, fingernail punctated rim; $\mathrm{j}$, brushed-incised rim sherd. 


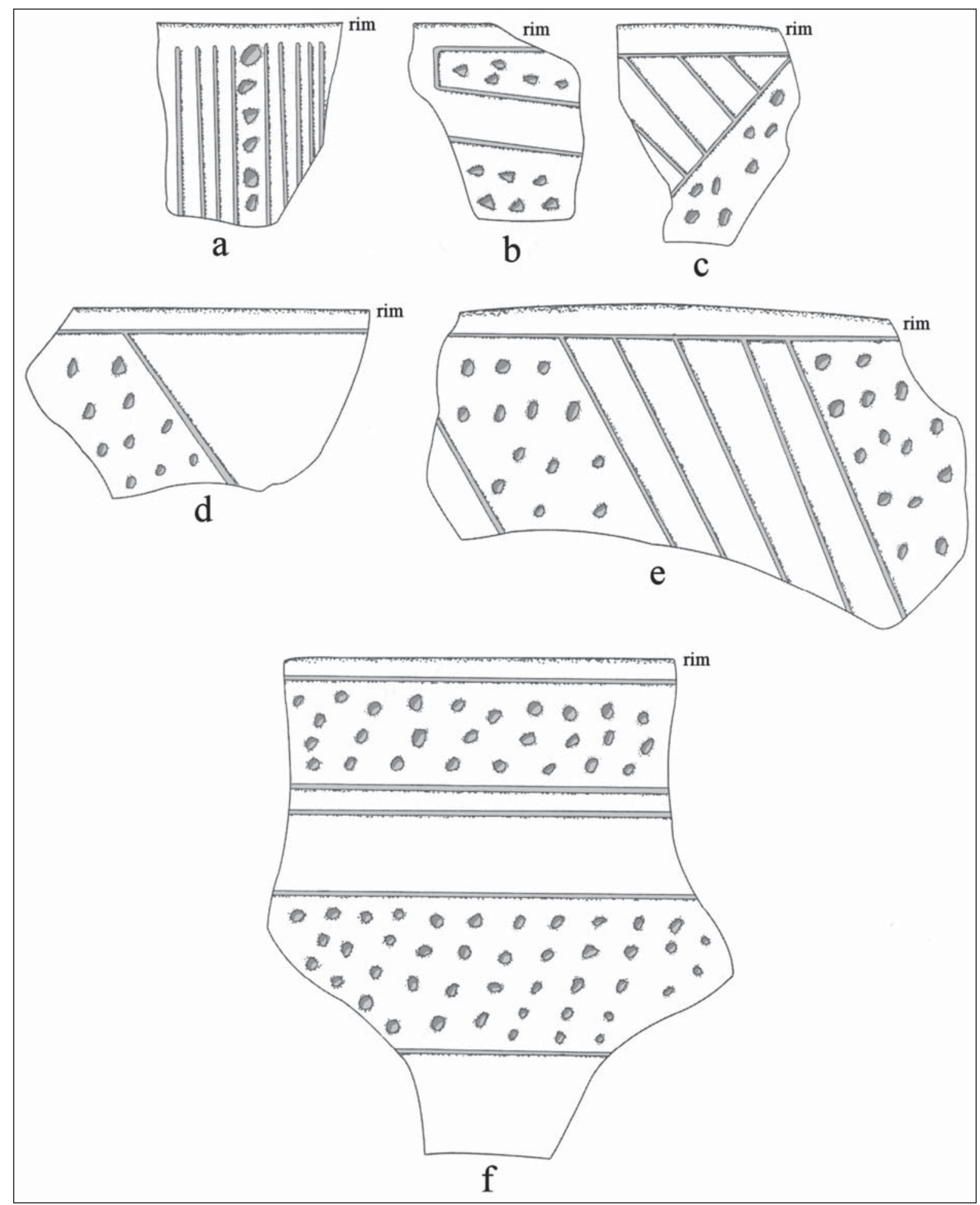

Figure 20. Incised-punctated rim sherds from the Horatio Kunaz site. 


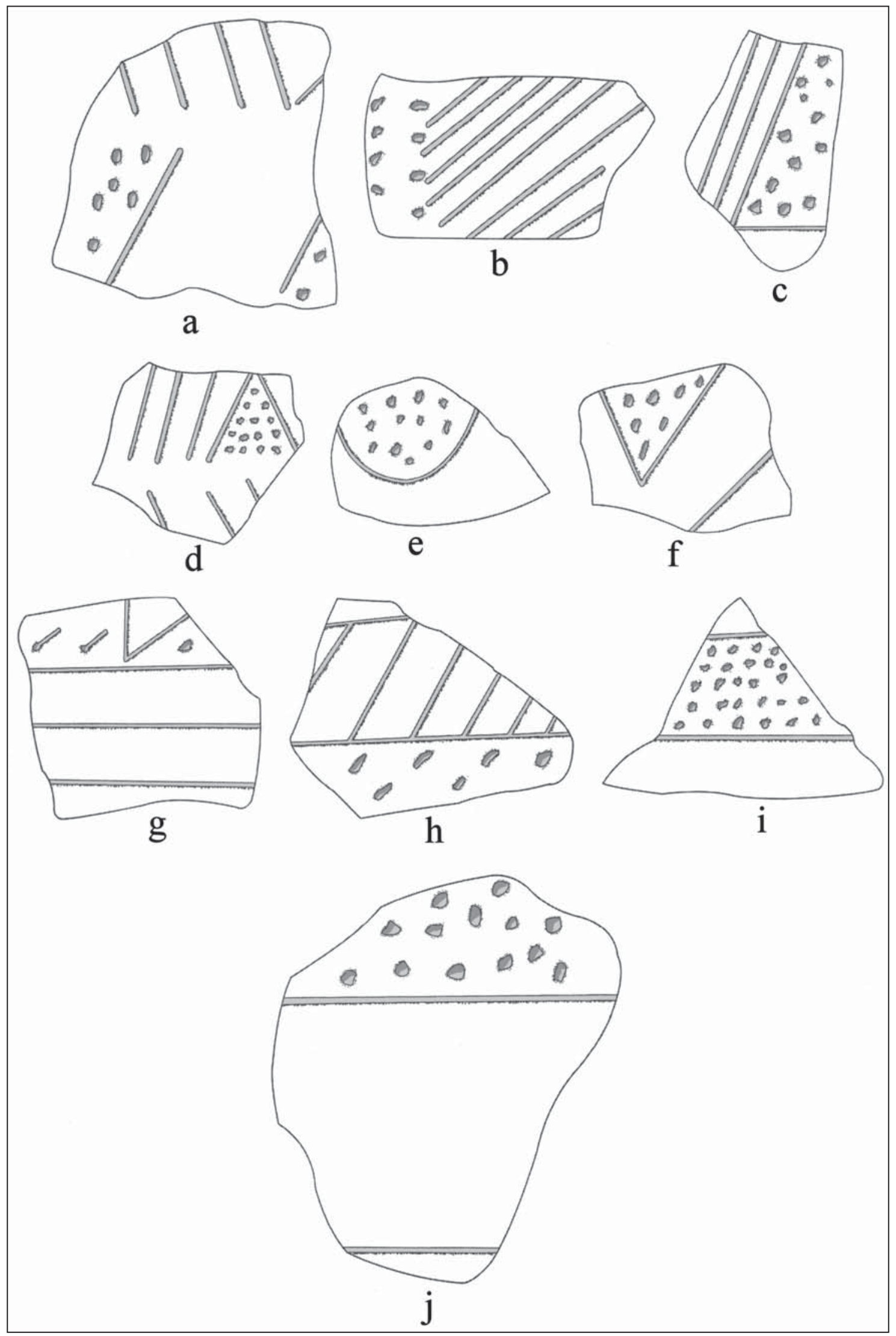

Figure 21. Body sherds with incised-punctated decorative elements. 


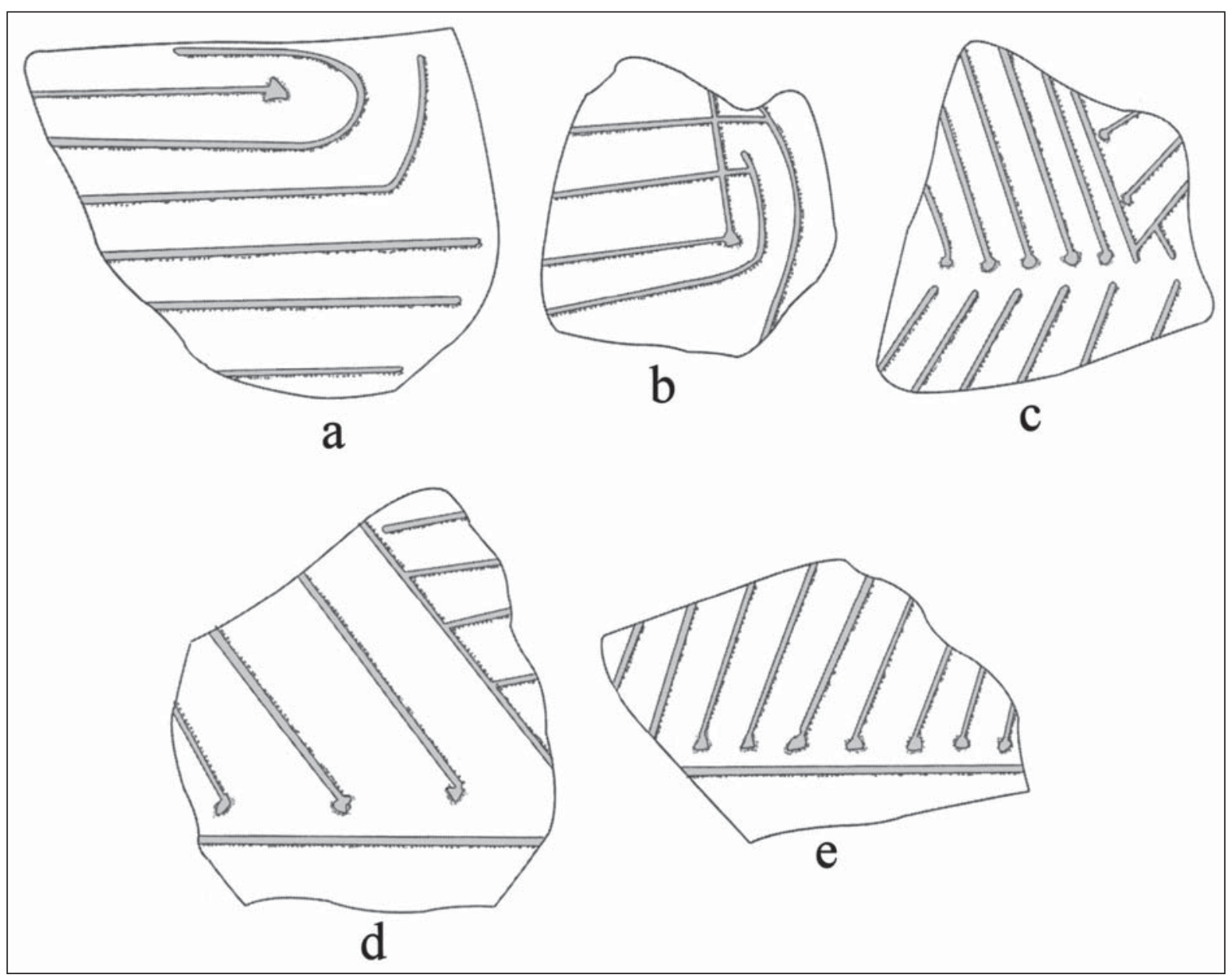

Figure 22. L'Eau Noire Incised body sherds from the Horatio Kunaz site.

The one pinched sherd in the assemblage may be from a Killough Pinched jar. The punctated sherds have circular, fingernail (see Figure 19i), and tool punctated rows (see Table 15) on the rim and/or the body of utility ware jars or carinated bowls ( 25 percent of the punctated sherds), perhaps mainly Kiam Incised or Weches Fingernail Impressed types. The use of tools (i.e., wooden dowels) for ceramic vessel decorative purposes is prevalent at the site.

Only 1.4 percent of the utility ware sherds from the Horatio Kunaz site have ridged decorative elements (see Table 15). They are from Belcher Ridged, var. Belcher and Belcher Ridged, var. Byram Ferry vessels (see Girard 2007b), and are generally indicative of settlement of the site after ca. A.D. 1400, although the use of the site appears to have been relatively limited after that time as compared to before ca. A.D. 1400.

The 29 fine ware sherds are from vessels with engraved (89.7 percent), engraved-incised (3.4 percent), and trailed (6.9 percent) vessels (Table 16). The few engraved rim sherds have either horizontal lines, horizontal and closely-spaced curvilinear lines, or a distinctive carinated bowl with a circular cross-hatched zone with a small central cross-hatched circle next to a large cross-hatched engraved bracket (Figure 23a). 
Table 16. Decorative methods and elements in the fine ware sherds from the Horatio Kunaz site (16SA27).

\begin{tabular}{|c|c|c|c|}
\hline Decorative method & Rim & Body & $\mathrm{N}$ \\
\hline \multicolumn{4}{|l|}{ Engraved } \\
\hline circular cross-hatched el. and cross-hatched bracket & 1 & - & 1 \\
\hline continuous scroll el. and nested excised triangles & - & 1 & 1 \\
\hline cross-hatched zones & - & 6 & 6 \\
\hline curvilinear lines & - & 2 & 2 \\
\hline diagonal hatched zones & - & 1 & 1 \\
\hline horizontal lines & 1 & 2 & 3 \\
\hline horizontal and closely-spaced curvilinear lines & 1 & - & 1 \\
\hline horizontal line and diagonal opposed excised zones & - & 1 & 1 \\
\hline parallel lines & - & 5 & 5 \\
\hline straight line & - & 3 & 3 \\
\hline straight line with linear tick marks & - & 1 & 1 \\
\hline vertical and curvilinear lines & - & 1 & 1 \\
\hline \multicolumn{4}{|l|}{ Engraved-Incised } \\
\hline $\begin{array}{l}\text { horizontal and vertical engraved lines and diagonal } \\
\text { incised line on folded over lip }\end{array}$ & 1 & - & 1 \\
\hline \multicolumn{4}{|l|}{ Trailed } \\
\hline curvilinear trailed lines & - & 2 & 2 \\
\hline Totals & 4 & 25 & 29 \\
\hline
\end{tabular}

Body sherds from engraved vessels have cross-hatched zones, diagonal hatched zones (see Figure 23d), probably from a Glassell Engraved vessel, and curvilinear lines (see Table 16). One Late Caddo period body sherd has a straight line with linear tick marks (see Figure 23c), a distinctive decorative element, as is a carinated bowl body sherd from another Late Caddo period vessel with a continuous scroll motif with nested excised triangles (see Figure 23b).

The one engraved-incised rim from the Horatio Kunaz site has vertical engraved panels with a set of diagonal engraved lines as well as a row of short diagonal incised lines under the exterior flattened vessel lip (see Figure 23f-f'). The other fine ware sherds from the site have broad curvilinear trailed lines (see Figure 23e) and are from Keno Trailed bowls.

In addition to the ceramic vessel sherds, there are five ceramic pipe sherds in the artifact assemblage from the site. One sherd (6.9 mm thick), grog-tempered, may be part of the butt end of an elbow pipe, while the other four are elbow pipe bowl sherds: two flat rims and two body or lower rim sherds. Three of the four sherds are from grog-tempered pipes, and the fourth pipe sherd is from a bone-tempered elbow pipe. Bowl wall thickness ranges from 5.4-7.3 $\mathrm{mm}$, with a mean wall thickness of $5.95 \mathrm{~mm}$.

A number of arrow points, preforms, and fragments have been recovered in the investigations at the Horatio Kunaz site (Table 17). The majority of the points identifiable to type are either Alba or Perdiz, suggesting Caddo occupations that date both before and after ca. A.D. 1200. 


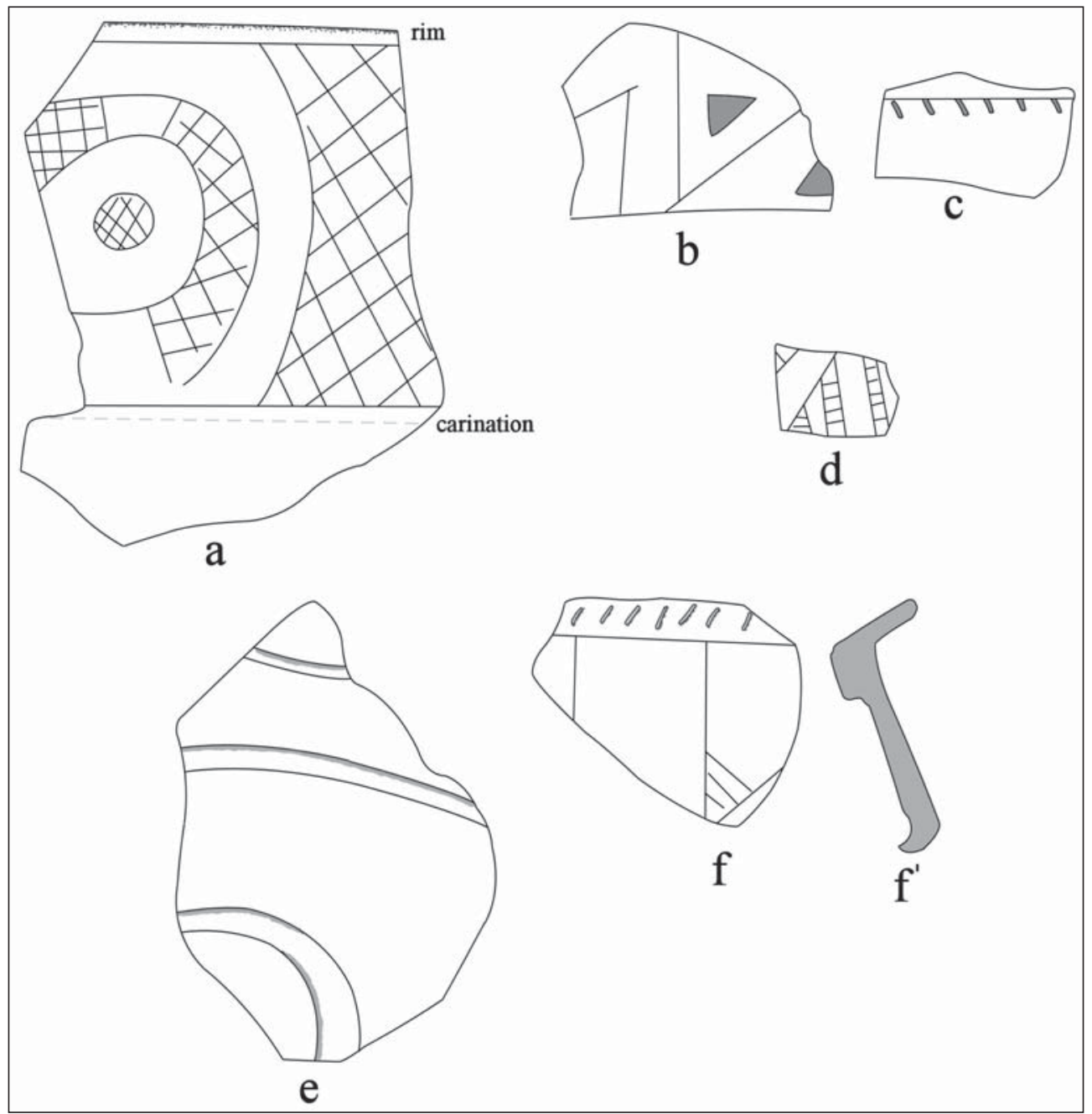

Figure 23. Selected decorative elements on fine ware sherds from the Horatio Kunaz site: a-d, engraved rim and body sherds; e, trailed; f, engraved-incised rim sherd.

Table 17. Arrow points from the Horatio Kunaz site (16SA27).

\begin{tabular}{lllllll}
\hline Kind & $\begin{array}{l}\text { brown } \\
\text { chert }\end{array}$ & $\begin{array}{l}\text { red } \\
\text { chert }\end{array}$ & $\begin{array}{l}\text { reddish- } \\
\text { brown } \\
\text { chert }\end{array}$ & PW & Other* & N \\
\hline Alba & 3 & 1 & - & - & 1 & 5 \\
Colbert & - & 1 & - & - & - & 1 \\
Perdiz & 4 & 1 & 1 & 1 & - & 7 \\
preforms & 4 & - & - & - & - & 4 \\
fragments & 7 & 1 & - & - & 4 & 28 \\
\hline Totals & 18 & 4 & 1 & 1 & & 4 \\
\hline
\end{tabular}

*light gray chert $(\mathrm{n}=1)$; gray chert $(\mathrm{n}=3) ; \mathrm{PW}=$ petrified wood 
About 85 percent of the arrow points have been made from cherts (earth-toned brown, red, and reddish-brown) and petrified wood materials available in local gravels. The arrow points made from light gray chert and gray chert may have been made from raw materials not available in the Sabine River basin.

There is one other stone artifact made from a brown chert pebble. This is a tubular-shaped pebble with six engraved lines etched into the cortical surface (Figure 24). This possible ornament is $50 \mathrm{~mm}$ in length, $15-23 \mathrm{~mm}$ in width, and $14.5 \mathrm{~mm}$ in thickness.

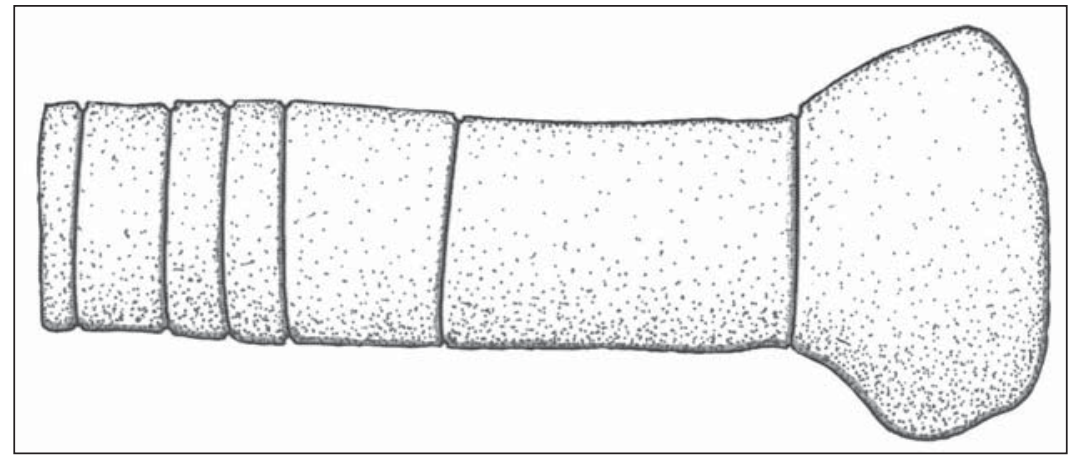

Figure 24. Engraved chert pebble from the Horatio Kunaz site.

\section{Bison Site, Area A (16SA30)}

The Bison site was on a natural rise on the east bank of the Sabine River (Scurlock and Davis 1962:50). It had extensive Caddo habitation deposits. UT excavations in 1963 consisted of several $5 \mathrm{x} 5 \mathrm{ft}$. units and a $3 \times 8 \mathrm{ft}$. trench, which identified archaeological deposits between $45-76 \mathrm{~cm}$ in thickness, along with midden deposits on the rise itself (Scurlock 1964:25-26).

UT returned to Area A of the Bison site in 1964-1965 to complete more extensive excavations (McClurkan et al. 1966:61-74). These excavations consisted of three backhoe trenches, a number of 3 x $10 \mathrm{ft}$. trenches across the southwestern part of the rise, and one $10 \times 12 \mathrm{ft}$. unit (Figure 25). The archaeological deposits ranged from the surface to ca. 46-122 cm bs and consisted of a "light tan or yellow-tan sand" (McClurkan et al. 1966:61). No cultural features were identified during the UT excavations.

The TARL collections from the site consist of a broad assortment of sherds $(\mathrm{n}=527)$ from Caddo grogand bone-tempered vessels (Table 18) and 11 arrow points. There are also two Woodland period Goose Creek Plain, var. unspecified body sherds, one from ca. $61-76 \mathrm{~cm}$ bs (level 5). About 95.6 percent of the sherds are from grog-tempered vessels and the remaining 4.4 percent are from bone-tempered sherds; the proportion of bone-tempered vessel sherds is 8.1 percent among the utility ware and fine ware. The decorative elements on the sherds are primarily consistent with a ca. A.D. 900-1200 Caddo occupation at the Bison site, Area A.

Table 18. Ceramic sherds from the Bison site, Area A (16SA30).

\begin{tabular}{llll}
\hline Ware & $\begin{array}{l}\text { Grog- } \\
\text { tempered }\end{array}$ & $\begin{array}{l}\text { Bone- } \\
\text { tempered }\end{array}$ & N \\
\hline Plain & 379 & 12 & 391 \\
Utility & 116 & 10 & 126 \\
Fine & 9 & 1 & 10 \\
\hline Totals & 504 & 23 & 527 \\
\hline
\end{tabular}




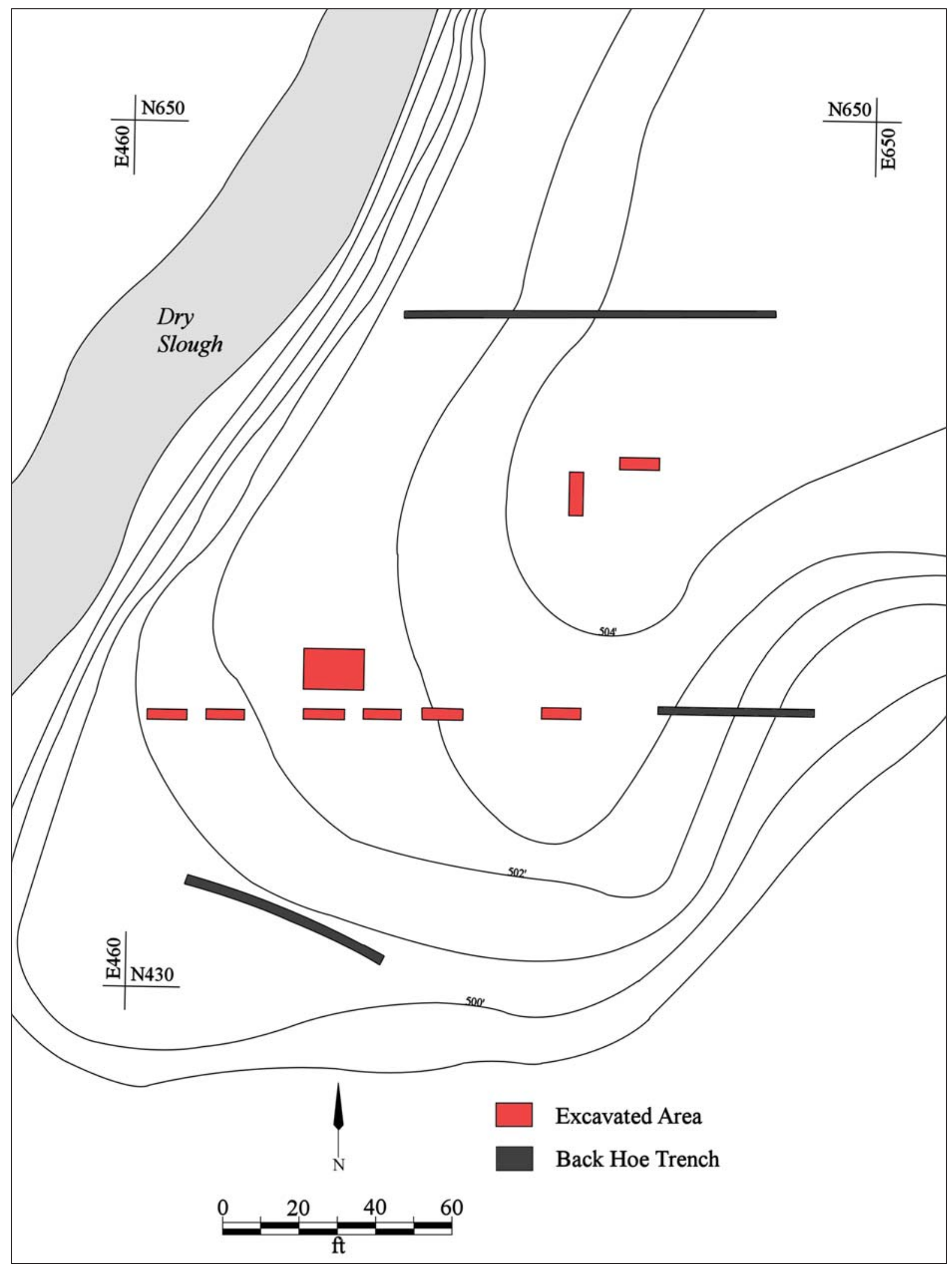

Figure 25. UT excavations at the Bison site, Area A (after McClurkan et al. 1966:Figure 30). 
Sherds from utility ware vessels represent more than 92 percent of the decorated sherds from the Bison site, Area A. The majority of the utility ware sherds have either punctated ( $\mathrm{n}=61,48$ percent of the utility wares) or incised ( $n=42,33$ percent) decorative elements (Table 19). The incised sherds are from Davis Incised and Dunkin Incised vessels (Figure 26c), while the punctated sherds are probably from Kiam Incised or Weches Fingernail Impressed jars.

Table 19. Decorative methods and elements in the Caddo sherds from the Bison site, Area A (16SA30).

\begin{tabular}{llll}
\hline $\begin{array}{l}\text { Method/ } \\
\text { element }\end{array}$ & Rim & Body & $\mathrm{N}$ \\
\hline
\end{tabular}

Utility Ware

\section{Brushed}

horizontal brushing marks

opposed brushing marks

parallel brushing marks

\section{Brushed-Incised}

horizontal brushed-incised marks and lines

parallel brushed and parallel incised lines

\section{Incised}

cross-hatched line

diagonal lines

diagonal opposed lines

horizontal lines

opposed lines

parallel lines

straight line

vertical lines

$\begin{array}{lll}1 & - & 1 \\ - & 1 & 1 \\ - & 6 & 6\end{array}$

\section{Incised-Punctated}

horizontal incised panels filled with

fingernail punctations; tool punctated

row at rim-body juncture

horizontal incised panel with linear tool

punctates in panel

straight line and adjacent crescent-shaped

fingernail punctated zone

straight line and adjacent tool punctated

zone

straight line and adjacent tool and fingernail

punctated zone

vertical incised panel filled with tool

punctates

Lip Notched

6


Table 19. Decorative methods and elements in the Caddo sherds from the Bison site, Area $A$ (16SA30), cont.

\begin{tabular}{|c|c|c|c|}
\hline $\begin{array}{l}\text { Method/ } \\
\text { element }\end{array}$ & Rim & Body & $\mathrm{N}$ \\
\hline \multicolumn{4}{|l|}{ Pinched } \\
\hline closely-spaced pinched ridges & - & 1 & 1 \\
\hline \multicolumn{4}{|l|}{ Punctated } \\
\hline fingernail punctated rows & 2 & 54 & 56 \\
\hline tool punctated rows & - & 5 & 5 \\
\hline \multicolumn{4}{|l|}{ Ridged } \\
\hline parallel ridged & - & 1 & 1 \\
\hline \multicolumn{4}{|l|}{ Ridged-Brushed } \\
\hline $\begin{array}{l}\text { parallel ridged with parallel brushing marks } \\
\text { between ridges }\end{array}$ & - & 2 & 2 \\
\hline \multicolumn{4}{|l|}{ Fine Ware } \\
\hline \multicolumn{4}{|l|}{ Engraved } \\
\hline cross-hatched and parallel lines & - & 1 & 1 \\
\hline curvilinear lines & - & 1 & 1 \\
\hline horizontal lines & 1 & - & 1 \\
\hline horizontal and sets of diagonal lines & - & 1 & 1 \\
\hline straight line & - & 6 & 6 \\
\hline Totals & 21 & 115 & 136 \\
\hline
\end{tabular}

Several of the sherds from incised-punctated vessels are from Weches Fingernail Impressed jars, including two sherds that have a row of tool punctations at the rim-body juncture (see Figure 26b, d). Another incised-punctated sherd has a vertical incised panel filled with tool punctates (see Figure 26a); this may be from a Pennington Punctated-Incised vessel. One body sherd with closely-spaced parallel pinched ridges may be from a Hollyknowe Ridge Pinched vessel (see Webb and McKinney 1975).

The majority of the engraved sherds are likely from carinated bowls and beakers. One sherd, possibly from a Holly Fine Engraved vessel, has sets of diagonal lines attached to a single horizontal engraved line (Figure 27a). Two of the engraved sherds are from bottles; one has curvilinear lines while the other has a cross-hatched zone and parallel diagonal engraved lines (Figure 27b).

Several of the utility wares suggest that there is a post-A.D. 1400 Caddo occupation in Area A at the Bison site. This includes Belcher Ridged, var. Byram Ferry $(\mathrm{n}=2)$ and var. Belcher $(\mathrm{n}=1)$ sherds as well as a few brushed $(n=8)$ and brushed-incised $(n=2)$ sherds (see Table 19). All told, these few sherds represent only 10.3 percent of the utility wares from the site.

There are 11 arrow points in the TARL collections from Area A at the Bison site. The temporally earliest of the points are three Woodland period (ca. A.D. 700-900) Friley arrow points made from red chert $(n=2)$ or petrified $\operatorname{wood}(\mathrm{n}=1)$. The remainder are Early Caddo period types, including Colbert ( $\mathrm{n}=1$, red chert), Catahoula $(\mathrm{n}=1$, red chert), and Alba ( $\mathrm{n}=6,1$ red chert, 3 brown chert, 1 yellowish-brown chert, and 1 dark gray chert). 


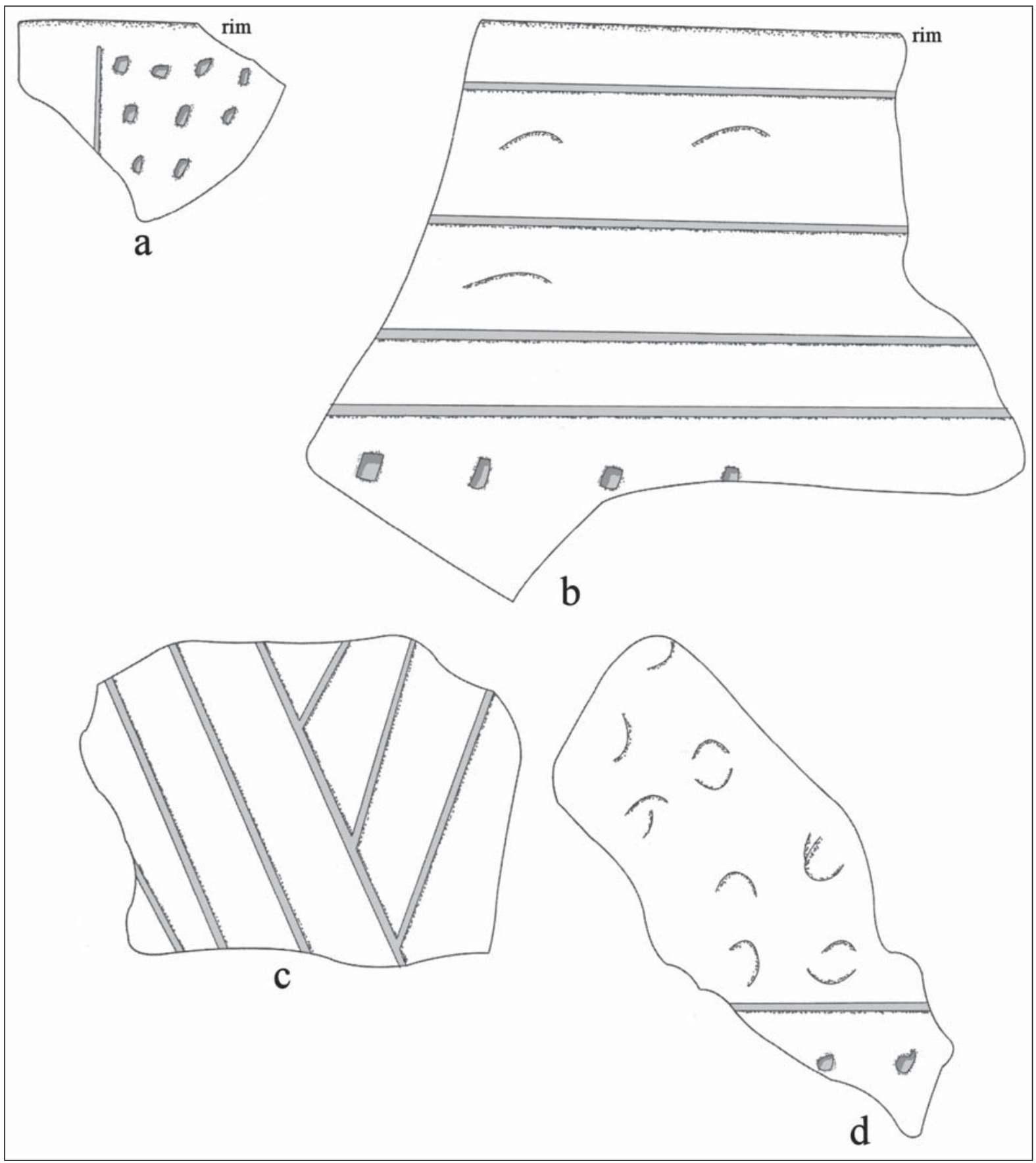

Figure 26. Selected utility ware decorative elements from Area A at the Bison site: a, incised-punctated rim; b, d, Weches Fingernail Impressed rim and body sherds; c, Dunkin Incised body sherd.

\section{Bison Site, Area B (16SA30)}

There are material culture remains in the TARL collections from two of the excavated features in Area B at the Bison site. Area B is about 300 meters south of Area A (Scurlock and Davis 1962:50; Scurlock 1964:2526; Woodall 1969:26). The features at the site are on a sandy rise on an alluvial terrace overlooking Brown's Bend on the Sabine River. The midden-covered rise had a number of Late Caddo period burials, including Features 1-2, 4-8, 12, 14-21, as well as two large pits (Feature 3, 11), five small (38-53 cm in diameter) pits, 14 post holes from parts of one or two Caddo structures, and a clay hearth (Feature 13) (Woodall 1969:29-39). 


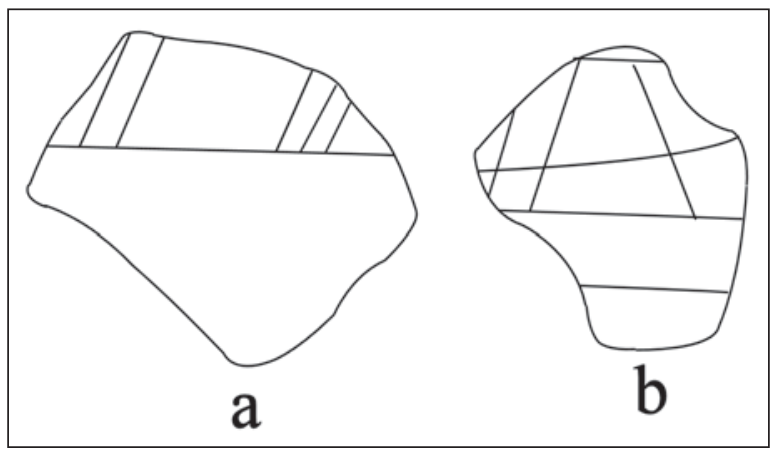

Figure 27. Selected decorative elements on engraved body sherds from the Bison site, Area A.

In Feature 11, a large pit filled with midden debris, was a broken deer antler tine tool (Figure 28). The fragmentary tool is at least $84.5 \mathrm{~mm}$ in length, $19.8 \mathrm{~mm}$ in width, and $14.0 \mathrm{~mm}$ in thickness, with worn/ polished areas near the tool's tip.

There is also a concentration of green glauconitic clay pigment from Feature 17, a burial feature (Woodall 1969:36-37). The pigment offering was found near the right foot of the deceased individual.

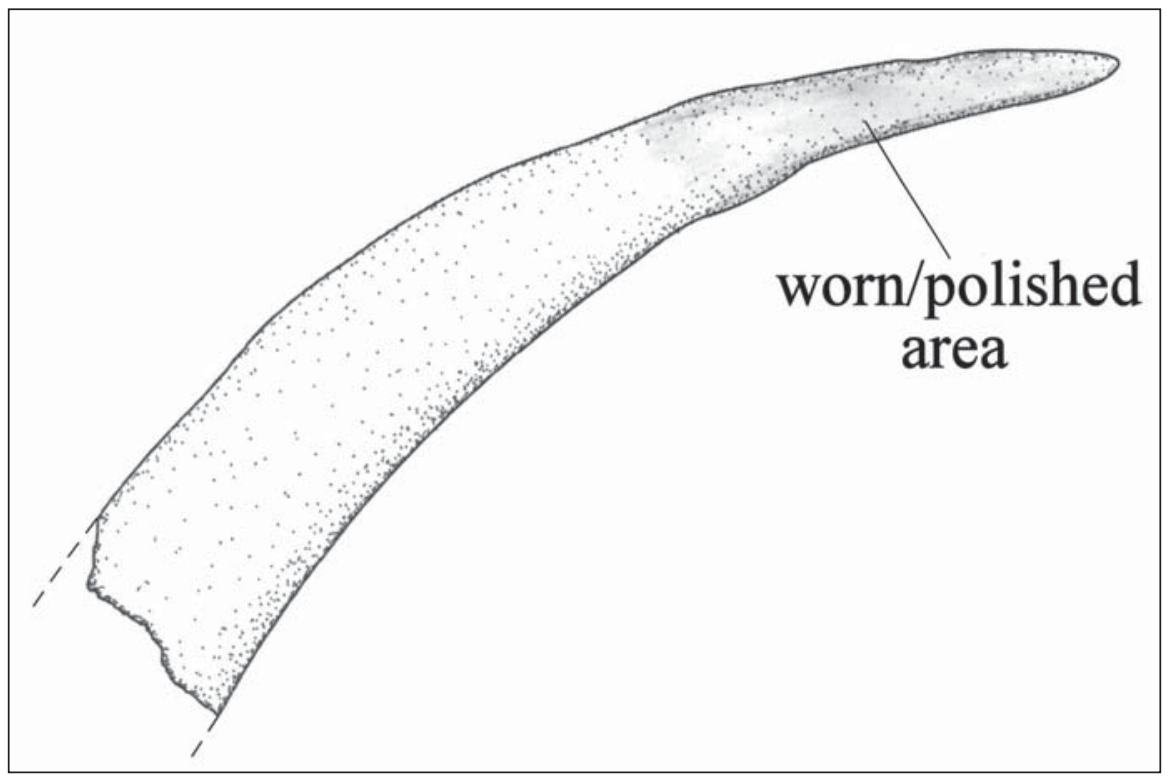

Figure 28. Antler tine tool from Feature 11 at the Bison site, Area B.

\section{Bison Site (16SA30), Unknown Area}

An unknown area at the Bison site investigated by UT in 1962-1963 (Scurlock 1964) has a few grog-tempered or bone-tempered sherds, most notably a Belcher Ridged, var. Belcher body sherd. Other decorated sherds from this area - which is probably Area B given the apparent age of the ceramic sherds-include brushed, diagonal opposed incised, and closely spaced parallel incised decorative elements. 


\section{Salt Works Lake Site (16SA47)}

The Salt Works Lake site was located along the northern edge of a small dry lake bed (McClurkan et al. 1966:1) in the Sabine River valley. According to McClurkan et al. (1966:1), "a great deal of pottery has weathered out of the bank and a surface collection was made...time and weather prohibited further excavation at the site."

A large assemblage of Late Caddo period ceramic sherds ( $\mathrm{n}=922)$ are in the TARL collections from the site. There is also one Woodland period Goose Creek Plain, var. unspecified sandy paste sherd in the collection from the site. The sherds are from both bone-tempered (63 percent of the assemblage) and grog-tempered (37 percent) vessels; there is also one plain shell-tempered sherd (Table 20).

Table 20. Caddo ceramic sherds from the Salt Works Lake site (16SA47).

\begin{tabular}{lllll}
\hline Ware & $\begin{array}{l}\text { Grog- } \\
\text { tempered }\end{array}$ & $\begin{array}{l}\text { Bone- } \\
\text { tempered }\end{array}$ & $\begin{array}{l}\text { Shell- } \\
\text { tempered }\end{array}$ & N \\
\hline Plain & 278 & 482 & 1 & 761 \\
Utility & 43 & 72 & - & 115 \\
Fine & 15 & 31 & - & 46 \\
\hline Totals & 336 & 585 & 1 & 922 \\
\hline
\end{tabular}

About 71 percent of the decorated sherds are from utility ware vessels, and the remainder are from engraved and trailed fine ware vessels (Table 21). Proportionally, the most common decorative methods in the assemblage from the Salt Works Lake site are brushed $(n=75,47$ percent of all the decorated sherds) and engraved ( $n=41,25$ percent), followed by incised ( $n=15,9$ percent), brushed-incised ( $n=9,5.6$ percent), and ridged ( $\mathrm{n}=6,3.7$ percent). The considerable amount of brushed pottery (albeit all body sherds), as well as Belcher Ridged, var. Belcher jar sherds, and the distinctive motifs on the engraved and trailed fine ware sherds indicate that the principal occupation at the site took place after ca. A.D. 1500, contemporaneous with the Belcher phase in the Red River valley (cf. Kelley 2006), and the occupation may have lasted into the 17 th century.

Table 21. Decorative methods and elements in utility ware and fine ware sherds from the Salt Works Lake site (16SA47).

\begin{tabular}{llll}
\hline $\begin{array}{l}\text { Method/ } \\
\text { Decorative element }\end{array}$ & Rim & Body & N \\
\hline
\end{tabular}

Utility Ware

Appliqued

horizontal and vertical appliqued fillets

opposed appliqued ridges

$\begin{array}{lll}- & 1 & 1 \\ - & 1 & 1\end{array}$

\section{Brushed}

curvilinear brushing marks

horizontal brushing marks

opposed brushing marks

parallel brushing marks

$\begin{array}{lll}- & 5 & 5 \\ - & 1 & 1 \\ - & 1 & 1 \\ - & 68 & 68\end{array}$

Brushed-Incised

curvilinear brushed-incised zones

-
- 
Table 21. Decorative methods and elements in utility ware and fine ware sherds from the Salt Works Lake site (16SA47), cont.

\begin{tabular}{llll}
\hline Method/ & Rim & Body & $N$ \\
Decorative element & & \\
\hline
\end{tabular}

diagonal incised-vertical brushed

parallel brushed-incised marks and lines

vertical incised line and opposed brushing marks

$\begin{array}{lll}- & 2 & 2 \\ - & 2 & 2 \\ - & 2 & 2\end{array}$

\section{Incised}

diagonal lines

parallel lines

straight line

vertical lines

$\begin{array}{lll}1 & - & 1 \\ - & 8 & 8 \\ - & 3 & 3 \\ 2 & 1 & 3\end{array}$

\section{Incised-Punctated}

diagonal lines and tool punctated row at rim-body

juncture

horizontal lines and tool punctated row under lip

straight incised line and adjacent tool punctated row

\section{2}

2

\section{Punctated}

circular punctated rows

tool punctated row on folded over lip

Ridged

parallel ridged

6

\section{Ridged-Brushed}

parallel ridges and parallel brushing between ridges

\section{Fine Ware}

\section{Engraved}

curvilinear lines

diagonal lines

diagonal opposed hatched zones

hooked arm element

horizontal lines

horizontal lines and excised pendant triangle

horizontal line and slanted scroll element

opposed lines

parallel lines

rectilinear elements

rectilinear element and narrow hatched zone

slanted scroll element

straight line

straight line and excised pendant triangles

tear drop element

$\begin{array}{lll}- & 2 & 2 \\ 3 & 1 & 4 \\ 1 & - & 1 \\ - & 1 & 1 \\ 6 & 1 & 7 \\ 1 & - & 1 \\ 1 & - & 1 \\ - & 5 & 5 \\ - & 3 & 3 \\ - & 6 & 6 \\ - & 1 & 1 \\ 5 & - & 5 \\ - & 2 & 2 \\ - & 1 & 1 \\ 1 & - & 1\end{array}$


Table 21. Decorative methods and elements in utility ware and fine ware sherds from the Salt Works Lake site (16SA47), cont.

\begin{tabular}{|c|c|c|c|}
\hline $\begin{array}{l}\text { Method/ } \\
\text { Decorative element }\end{array}$ & Rim & Body & $\mathrm{N}$ \\
\hline \multicolumn{4}{|l|}{ Engraved-Brushed } \\
\hline $\begin{array}{l}\text { curvilinear engraved lines on rim and horizontal brushed } \\
\text { body }\end{array}$ & - & 1 & 1 \\
\hline $\begin{array}{l}\text { horizontal engraved lines on rim and horizontal brushed } \\
\text { body }\end{array}$ & - & 1 & 1 \\
\hline horizontal engraved line on rim and vertical brushed body & - & 1 & 1 \\
\hline vertical cross-hatched column and vertical brushed body & - & 1 & 1 \\
\hline \multicolumn{4}{|l|}{ Trailed } \\
\hline curvilinear trailed lines & - & 2 & 2 \\
\hline Totals & 25 & 136 & 161 \\
\hline
\end{tabular}

Appliqued sherds comprise 1.7 percent of the utility wares (see Table 21). The sherds have either appliqued fillets (Figure 29a) or appliqued ridges. The bodies of a number of utility ware vessels have brushed decorative elements, including curvilinear, opposed, overlapping, and parallel brushing marks; the parallel brushing marks on sherds are probably indicative of vertical brushing on vessel bodies. Almost 8 percent of the utility ware sherds have brushed-incised decorative elements, including three Mound Tract Incised and Brushed sherds (see Kelley 1997:52) with curvilinear incised zones filled with brushing marks (Figure 29b-c). According to Kelley (1997:52), Mound Tract Incised sherds and vessels have been recovered from Belcher phase contexts on Red River Caddo sites. Another brushed-incised sherd has diagonal incised lines on the lower rim and vertical brushing on the vessel body (Figure 29e).

There are 15 sherds with incised decorative elements at the site (see Table 21), and another 3.5 percent are from vessels with incised-punctated decorative elements. This includes one rim with diagonal incised lines as well as a row of tool punctates at the rim-body juncture (see Figure 29d).

Approximately 6 percent of the utility ware sherds are from Belcher Ridged vessels (see Table 21). This includes one 15th century A.D. Belcher Ridged, var. Byram Ferry sherd and six post-A.D. 1500 Belcher Ridged, var. Belcher sherds.

The fine ware sherds from the Salt Works Lake site are from both trailed (4.3 percent of the fine wares), engraved (87 percent), and engraved-brushed ( 8.7 percent) vessels. The trailed sherds are from Keno Trailed bowls.

A number of rim sherds have horizontal engraved lines (see Table 21), but the overall design motif is not known. At least two of the engraved sherds have an horizontal engraved line with a row of excised pendant triangles (Figure 30a, e), and these may be from Ripley Engraved, var. McKinney vessels. One Taylor Engraved carinated bowl sherd in the assemblage has a hooked arm element (Figure 30b).

Sherds with rectilinear engraved elements are from Glassell Engraved carinated bowls (see Figure 30d). The sherds with slanted scroll elements (see Figure 30f, i-j) are also from varieties of Glassell Engraved (see Kelley 1997:Figure 35). Other distinctive engraved decorative elements in the fine ware sherds include a rim with diagonal opposed hatched zones (see Figure $30 \mathrm{~g}$ ) and a carinated bowl rim with a tear drop element. This element includes a curvilinear zone with an inner excised tear drop-shaped element (see Figure 30h). 


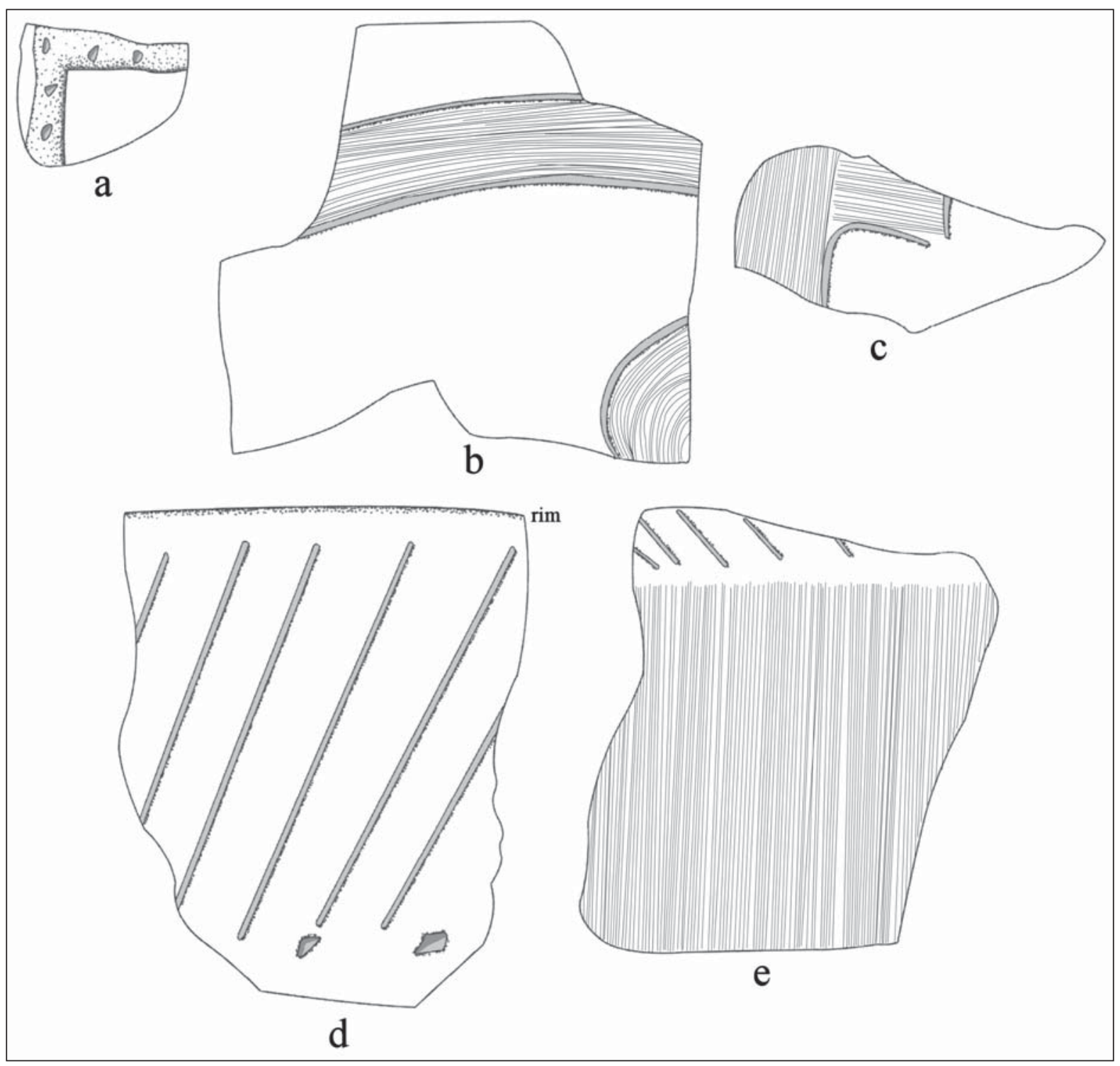

Figure 29. Selected decorative elements on utility ware sherds from the Salt Works Lake site (16SA47): a, appliqued fillets on body sherd; $b$-c, curvilinear brushed-incised body sherds; $d$, incised-punctated rim sherd; e, brushed-incised lower rim and body sherd.

The engraved-brushed vessels are a distinctive part of the fine wares at the Salt Works Lake site. One sherd has a vertical cross-hatched engraved ladder on the rim and vertical brushing on the body; two others have a horizontal engraved line on the lower rim and either horizontal or vertical brushing marks on the vessel body. A carinated bowl sherd has broad curvilinear engraved lines on the rim and horizontal brushing marks on the vessel body (see Figure 30c). 


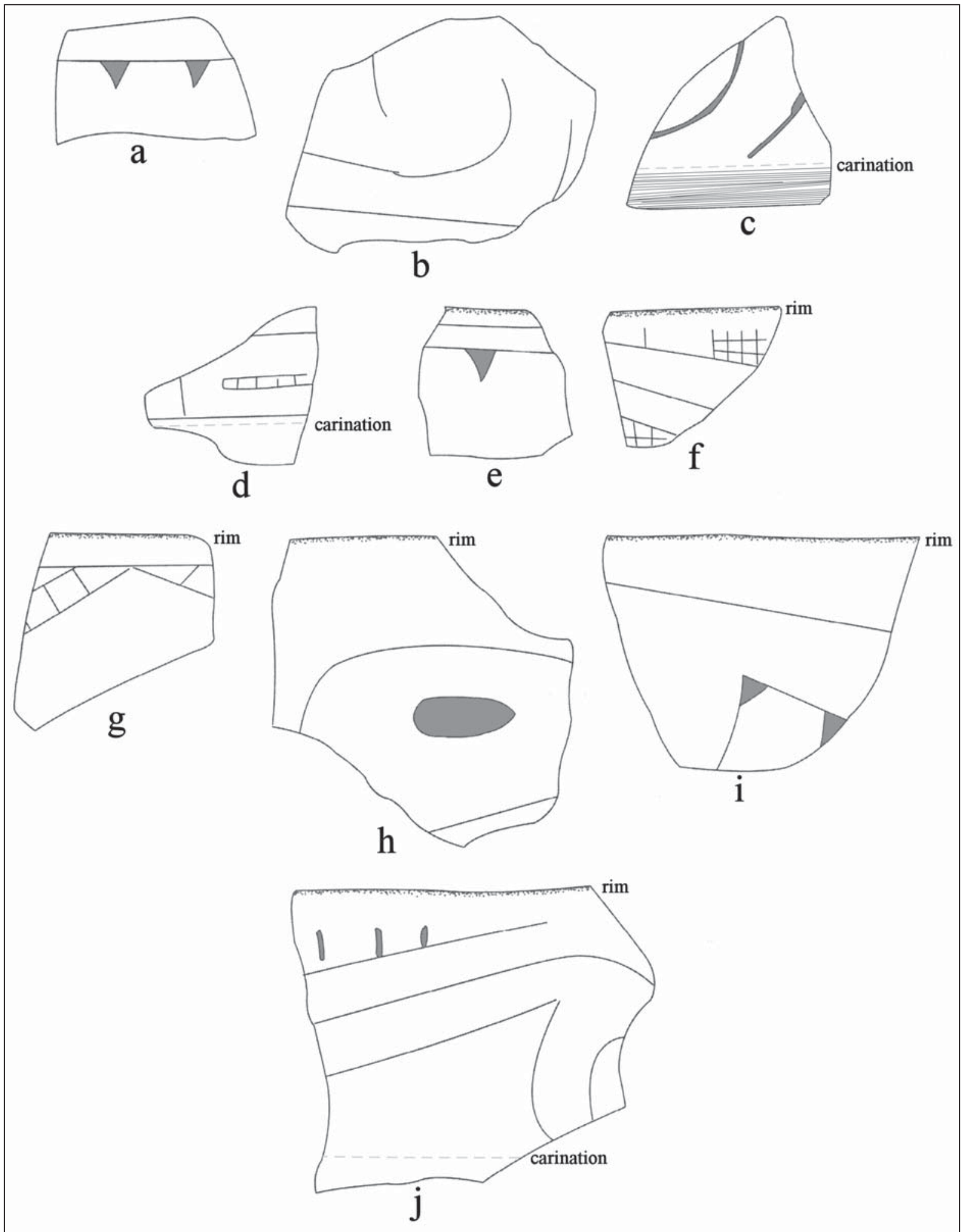

Figure 30. Selected decorative elements on fine ware sherds from the Salt Works Lake site (16SA47): a, excised pendant triangles on rim and body sherds; b, Taylor Engraved body sherd; c, curvilinear engravedhorizontal brushed; d, Glassell Engraved body sherd; f, i-j, slanted scroll on rim sherd; g, diagonal opposed hatched zones on rim sherd; h, rim sherd with tear drop element. 


\section{$16 \mathrm{SA101}$}

This site was investigated by SMU during the 1967-1968 season at Toledo Bend Reservoir (Benham et al. 1973:20-36). The work consisted of the hand excavation of a number of $1 \times 5 \mathrm{~m}$ or $1 \mathrm{x} 10 \mathrm{~m}$ trenches and nine test pits of various sizes (Benham et al. 1973:Figure 3) on a terrace (160 ft. amsl) above the Slaughter Creek floodplain. During the work three pit features (Features 26-28) were identified, along with five artifact clusters at the northern and southern ends of the landform (Figure 31).

The initial and very limited occupation of 16SA101 took place during the latter part of the Woodland period (post-dating ca. A.D. 700). This is evidenced by a reddish-brown chert Friley arrow point and two Goose Creek Plain, var. unspecified sherds in the collection: a base and body sherd.

The Caddo ceramic assemblage from the site consists of sherds $(n=607)$ primarily from grog-tempered plain ware, utility ware, and fine ware vessels; approximately 93 percent of the sherds from all three wares are from grog-tempered vessels (Table 22). Another 6.8 percent of the sherds are from bone-tempered vessels, and only 0.2 percent of the sherds are from shell-tempered vessels. One of the plain grog-tempered body sherds has been worked into a $41 \mathrm{~mm}$ ceramic disk.

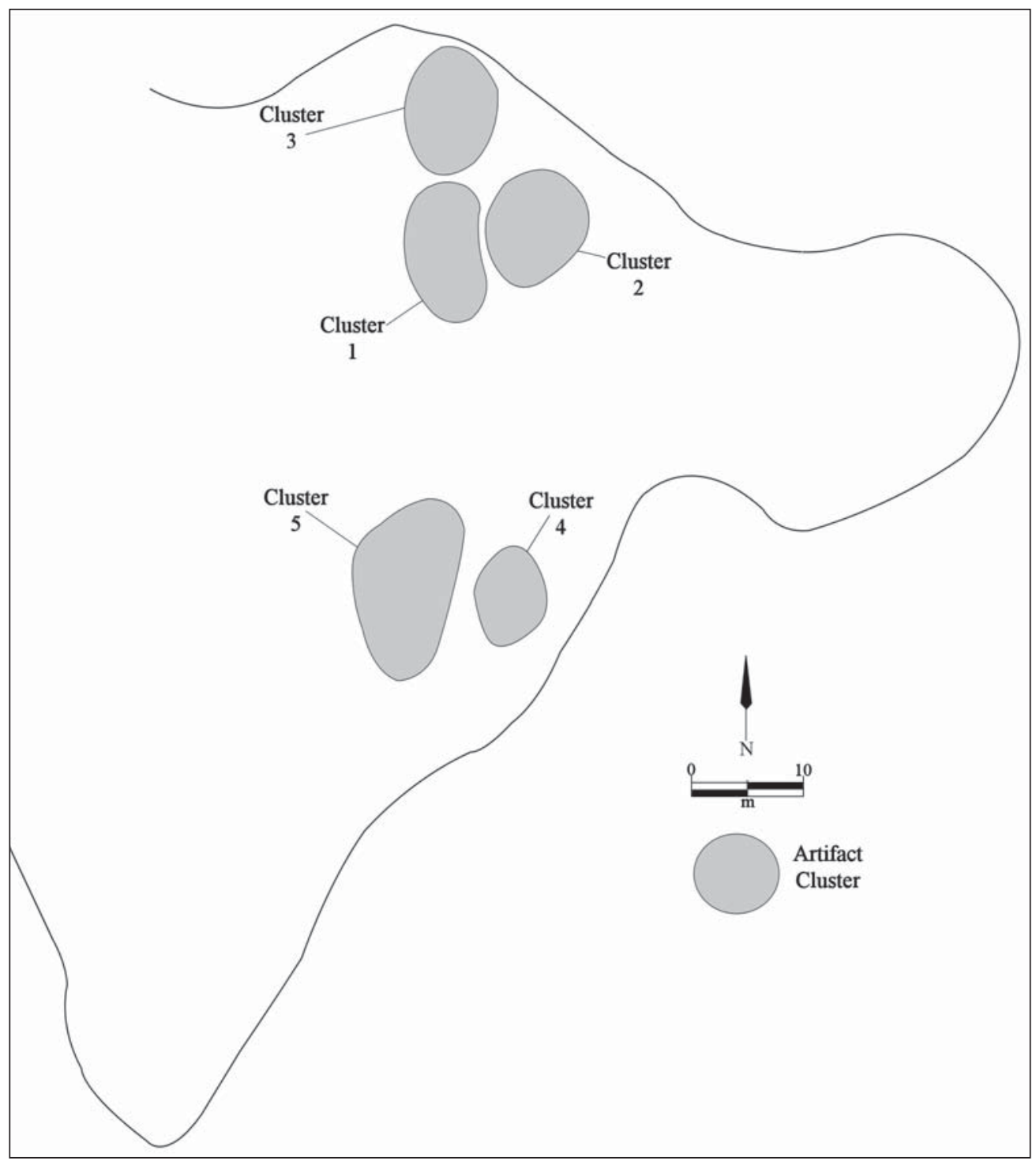

Figure 31. Plan of 16SA101 and artifact clusters 1-5. 
Table 22. Caddo ceramic sherd assemblage from 16SA101.

\begin{tabular}{lllll}
\hline Ware & $\begin{array}{l}\text { Grog- } \\
\text { tempered }\end{array}$ & $\begin{array}{l}\text { Bone- } \\
\text { tempered }\end{array}$ & $\begin{array}{l}\text { Shell- } \\
\text { tempered }\end{array}$ & N \\
\hline Plain & 289 & 25 & - & 314 \\
Utility & 265 & 15 & - & 280 \\
Fine & 11 & 1 & 1 & 13 \\
\hline Totals & 565 & 41 & 1 & 607 \\
\hline
\end{tabular}

More than 95 percent of the 293 decorated sherds from 16SA101 are from utility ware jars and bowls; only 4.4 percent are from engraved or trailed fine ware vessels (see Table 22). The utility ware sherds are primarily from vessels with incised decorative elements: 77 percent of the utility wares and 85 percent of the utility ware rims (Table 23). The next most common utility ware are sherds from punctated vessels and they only comprise 13 percent of the utility wares and 6 percent of the utility ware rims. Incised-punctated sherds represent 7.5 percent of the utility ware assemblage and 9.6 percent of the utility ware rims. Sherds from brushed vessels - either with brushing as the sole decorative element or brushing in combination with either incised lines or punctations - only account for 2.1 percent of the utility ware sherds.

Table 23. Decorative methods and elements in the utility ware and fine ware sherds from 16SA101.

\begin{tabular}{lllll}
\hline $\begin{array}{l}\text { Method/ } \\
\text { decorative element }\end{array}$ & Rim & Body & N \\
\hline
\end{tabular}

Utility Ware

Brushed

parallel brushed

$\begin{array}{lll}- & 1 & 1 \\ - & & \\ - & 1 & 1 \\ - & 1 & 1 \\ & 2 & 2 \\ - & & \\ & 1 & 1 \\ & & \\ - & & \\ 1 & 1 & 1 \\ 1 & 1 & 2 \\ 3 & 3 & 3 \\ 2 & - & 2 \\ - & - & 19 \\ 1 & 19 & 1 \\ 21 & - & 22 \\ 12 & 1 & 17 \\ 2 & 5 & 3 \\ 1 & 1 & 1 \\ - & - & 10 \\ - & 10 & 100\end{array}$

Brushed-Incised

parallel brushed-incised marks and lines parallel brushed-overlying opposed parallel lines

parallel brushed-overlying straight line

Brushed-Punctated

circular punctated row and adjacent parallel brushing

Incised

cross-hatched lines

curvilinear line/lines

curvilinear and rectilinear incised panels

diagonal lines

diagonal hatched panel

diagonal opposed lines

hatched incised triangle

horizontal lines

horizontal and diagonal lines

horizontal and diagonal opposed lines

horizontal and vertical lines

opposed lines

100

100 
Table 23. Decorative methods and elements in the utility ware and fine ware sherds from 16SA101, cont.

Method/

decorative element

parallel lines, closely-spaced

parallel and diagonal lines

straight line

vertical panels filled with diagonal opposed lines

\section{Incised-Punctated}

curvilinear and rectilinear panels; inner panel

line begins at tool punctate

diagonal lines and adjacent tool punctated row

horizontal lines and circular zone filled with circular

punctates

horizontal lines above linear tool punctated rows

horizontal lines and tool punctate-filled incised triangle

horizontal lines and horizontal panel filled with tool

punctates

horizontal panel filled with tool punctated rows

incised triangles filled with circular punctates

incised triangles filled with tool punctates

panels filled with circular punctates

straight line and adjacent circular punctated zone

straight line and two adjacent circular punctated zones

straight line and adjacent tool punctated zone

\section{Punctated}

circular punctated rows

fingernail punctated rows

linear tool punctated rows

tool punctated rows

\section{Fine Ware}

Engraved

diagonal opposed hatched zones

hatched zone

hatched zone and diagonal lines

horizontal lines

horizontal and diagonal lines

horizontal line and hatched pendant triangle

horizontal line and hatched triangle

parallel lines

straight line

Rim Body N

$\begin{array}{ll}- & 1\end{array}$

$\begin{array}{ll}- & 17\end{array}$

$\begin{array}{ll}- & 11\end{array}$

$-\quad 2$

2$$
-
$$$$
-
$$

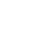$$
-
$$$$
2
$$

2

$$
1
$$$$
1
$$

$\begin{array}{lll}- & 3 & 3 \\ - & 21 & 21 \\ - & 2 & 2 \\ 3 & 8 & 11\end{array}$

\section{Trailed}

curvilinear trailed lines

\begin{tabular}{lll}
- & 1 & 1 \\
- & 1 & 1 \\
- & 1 & 1 \\
1 & 2 & 3 \\
- & 1 & 1 \\
1 & - & 1 \\
1 & - & 1 \\
- & 2 & 2 \\
- & 1 & 1 \\
& & \\
- & 1 & 1 \\
\hline 55 & 238 & 293 \\
\hline
\end{tabular}

Totals

55 
The occurrence of only a few sherds with brushed decorative elements suggests that the principal Caddo occupation at the site took place early in the Middle Caddo period (ca. A.D. 1200-1400), based on the manufacture of brushed vessels in the region beginning around ca. A.D. 1200. This temporal assessment is consistent with the presence of L'Eau Noire Incised sherds in the assemblage — dated by Brown $(1998: 7,57)$ to between ca. A.D. 1200-1350 — as well as diagonal opposed Pease Brushed-Incised body sherds, probably an early variety of this utility ware type.

The rim sherds with incised decorative elements are dominated by those with sets of horizontal lines $(n=21,48$ percent of the rims with incised elements), horizontal and diagonal lines ( $\mathrm{n}=12,27$ percent), and diagonal lines ( $\mathrm{n}=3,7$ percent) (see Table 23). The rims with sets of horizontal lines may be from Davis Incised, Dunkin Incised, or Kiam Incised vessels, but those with horizontal and diagonal opposed incised decorative elements (Figure 32c-d, g) are from Dunkin Incised vessels. A Kiam Incised vessel is represented by a lower rim-body sherd with sets of horizontal incised lines above another set of near-vertical incised lines on the vessel body (Figure $32 \mathrm{~h}$ ).

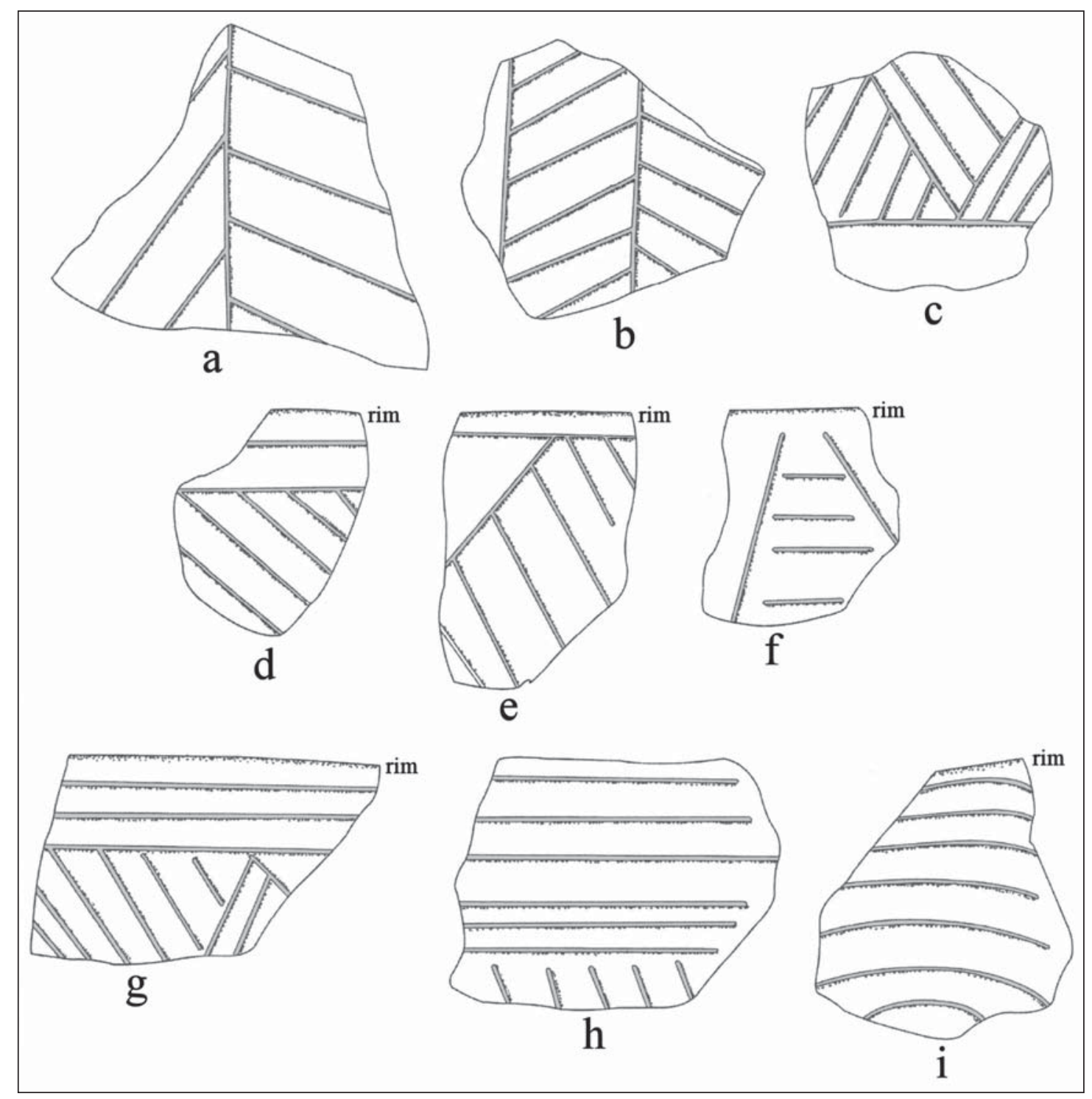

Figure 32. Selected incised decorative elements in utility ware sherds from 16SA101: a-b, Pease Brushed-Incised; c-d, g, Dunkin Incised; e, diagonal hatched panel; f, hatched incised triangle; h, Kiam Incised; i, multiple curvilinear incised lines on rim sherd. 
Other incised rim sherds from 16SA101 have hatched elements. Two rims have diagonal incised panels filled with hatched incised lines pitched in an opposite direction (see Figure 32e), and one rim has an incised triangle with horizontal hatched lines (see Figure 32f).

Two sherds with vertical incised panels filled with diagonal opposed lines are from Pease Brushed-Incised vessels (see Figure 32a-b; see also Suhm and Jelks 1962:Plate 60k). Also among the incised sherds are four rim or body sherds from L'Eau Noire Incised vessels with curvilinear and rectilinear panels. These may be from var. Bayou Bourbe vessels (see Brown 1998:15, 21).

The incised-punctated rim and body sherds include a variety of decorative elements. One sherd is from a L'Eau Noire, var. L'Eau Noire vessel (see Brown 1998:15, 57) that has rectilinear and curvilinear panels, and an inner line in a central panel begins at a small triangular-shaped punctation (Figure 33a). Another is from a Kiam Incised jar with horizontal incised lines on the rim and fingernail punctated rows on the vessel body (Figure 33b). Other incised-punctated sherds have an incised circle element, below two horizontal incised lines, filled with circular punctations (Figure 33c); these may be from Crockett Curvilinear Incised vessels.

There are several incised-punctated sherds that have incised triangle-shaped elements filled with tool punctations (see Figure 33d, f), or punctated-filled incised triangles embedded in sets of diagonal incised lines (see Figure 33e). Other rim sherds have horizontal incised panels filled with tool punctations, either as the principal rim decorative elements (see Figure 33g), or the horizontal incised panel occurs in association with other horizontal incised lines (see Figure 33h).

Most of the punctated sherds have fingernail (57 percent) or tool punctates (30 percent). These occur in rows on the rim and/or body of utility ware jars, and the fingernail punctated sherds may well be from Kiam Incised vessels (see Suhm and Jelks 1962:89).

The fine ware sherds include engraved ( $\mathrm{n}=12$ sherds, including three rims) and trailed $(\mathrm{n}=1)$ decorative elements. The one horizontal engraved rim sherd may be from a Hickory Engraved vessel. The most distinctive decorative elements include hatched zones (Figure 34c-d) in various orientations and horizontal engraved lines with attached hatched triangles or hatched pendant triangles (Figure 34a-b). These decorative elements are prevalent in Middle Caddo fine ware ceramic assemblages in the Sabine River basin.

The trailed sherd is from a ca. post-A.D. 1600 shell-tempered Keno Trailed bowl with curvilinear trailed lines. No other decorated ceramics of this age have been identified in the 16SA101 assemblage.

The Caddo chipped stone tools in the assemblage at 16SA101 includes 16 arrow points, preforms, and fragments, and three bifacial perforators. The two ovoid preforms are on local red and brownish-red chert, while the five fragments are on locally available petrified wood, reddish-brown chert, and yellow chert as well as probable non-local materials: gray chert and dark grayish-brown chert. Identified arrow point types include Alba ( $\mathrm{n}=7)$ and Perdiz $(\mathrm{n}=2)$. The Alba points are on local raw materials ( 2 brown chert, 3 red chert, 1 reddish-brown chert, and 1 petrified wood), and the Perdiz points are on a brown chert and a non-local grayish-white chert.

The bifacially chipped perforators are made from local raw materials: red chert $(n=2)$ and petrified wood. One red chert perforator is bi-pointed (Figure 35a), while the other two have flat bases and a curved tip (Figure -b-c).

Two European trade goods of 18th century age were recovered at 16SA101 during the excavations (Benham et al. 1973:35). One was a French iron knife and the other was an undecorated iron trigger guard from a musket suggested to date from A.D. 1725-1750. 


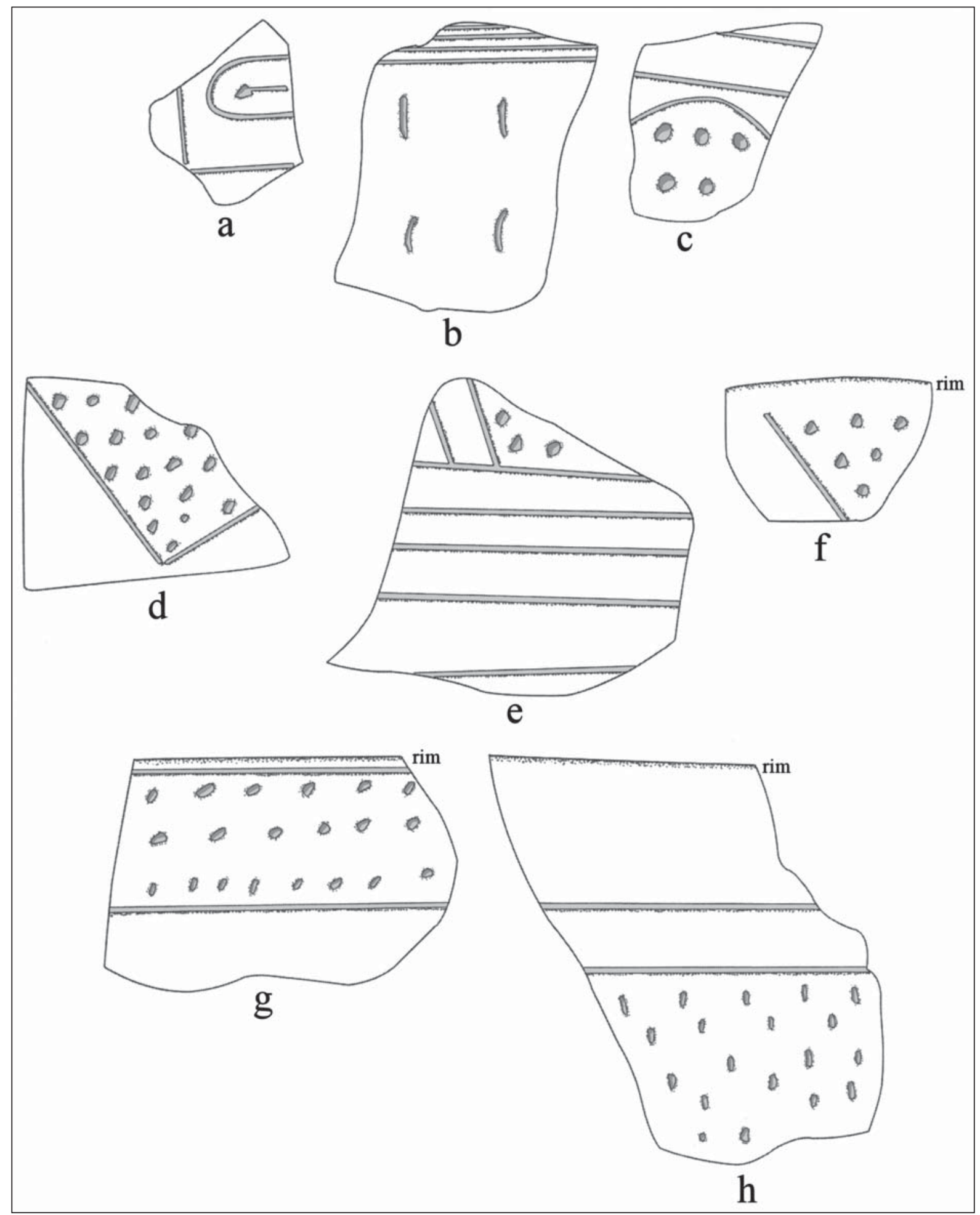

Figure 33. Selected incised-punctated decorative elements in utility ware sherds from 16SA101: a, L'Eau Noire Incised body sherd; b, Kiam Incised body sherd; c, incised-circular punctated zone; d-f, incised-triangular punctated zone; g-h, horizontal incised panel filled with punctates. 


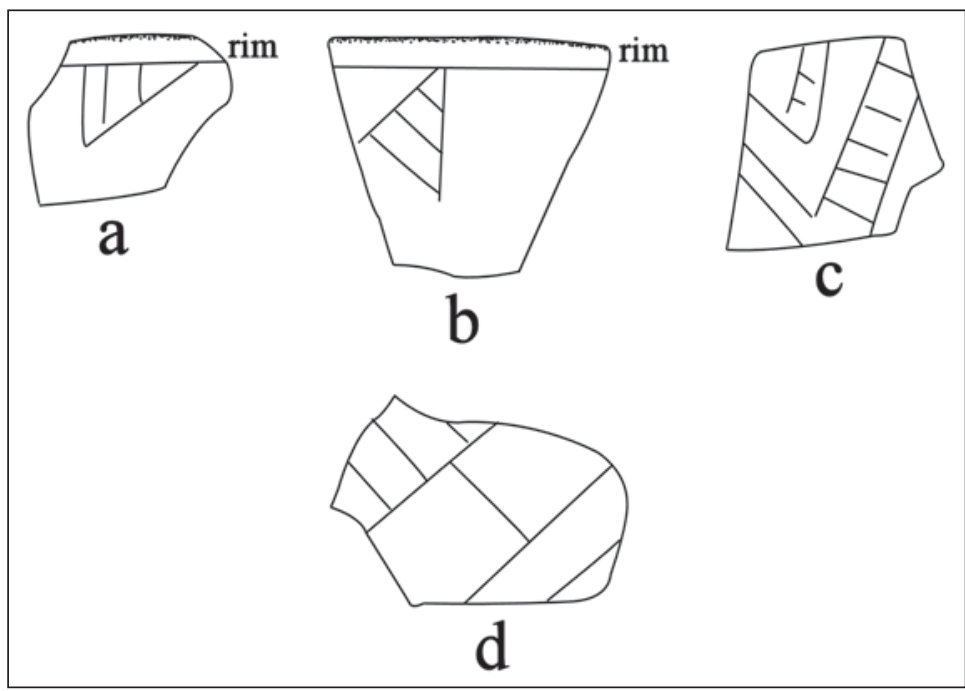

Figure 34. Selected decorative elements on fine ware sherds from 16SA101.

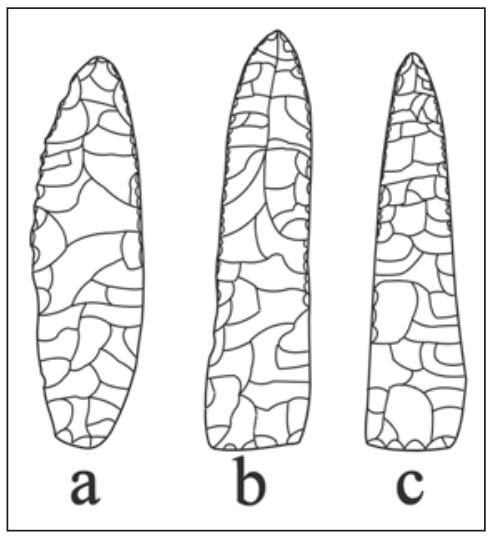

Figure 35. Bifacial perforators from 16SA101.

\section{Ceramic Vessels from Burials in Louisiana Sites at Toledo Bend Reservoir}

The TARL vessel collection from sites at Toledo Bend Reservoir include 26 vessels from four sites: Goode (16SA1), Bison, Area B (16SA30), Salt Lick (16SA37a), and Coral Snake (16SA48). Almost 90 percent of the vessels are from the Salt Lick site excavations conducted by University of Texas archaeologists in the Fall of 1964 (see McClurkan et al. 1966). With the exception of the two vessels from the Coral Snake site that date to the early part of the Middle Woodland period (ca. 100 B.C. to A.D. 100) (Jensen 1968a, 1968b), the other vessels are from post-A.D. 1400 Late Caddo period burial features at the other three sites.

The Goode site is on an alluvial rise in the Sabine River floodplain, ca. $60 \mathrm{~m}$ southeast of the Coral Snake Mound site (see Figure 1). SMU conducted excavations at the site in 1966 (Woodall 1969). The focus of the excavations was a midden deposit on the rise, and more than 8,000 Caddo sherds were recovered. Woodall (1969:11) noted that "the sherds are unusually large for a midden site; often a concentration of fragments was encountered which represented a large segment of a single broken vessel."

SITE NAME OR SITE NUMBER: Goode (16SA1)

VESSEL NO.: Lot 49

VESSEL FORM: Compound bowl with rim peaks

NON-PLASTICS AND PASTE: grog and bone

RIM AND LIP FORM: Everted rim and a rounded lip

CORE COLOR: $\mathrm{F}$ (fired in a reducing environment and cooled in the open air)

INTERIOR SURFACE COLOR: reddish-brown

EXTERIOR SURFACE COLOR: reddish-brown; fire clouds on the rim and body

WALL THICKNESS (IN MM): rim, $5.6 \mathrm{~mm}$; body, $5.3 \mathrm{~mm}$; base, $9.5 \mathrm{~mm}$ 
INTERIOR SURFACE TREATMENT: smoothed

EXTERIOR SURFACE TREATMENT: burnished

HEIGHT (IN CM): 9.5

ORIFICE DIAMETER (IN CM): 26.0

DIAMETER AT BOTTOM OF RIM OR NECK (IN CM): 17.5

BASE DIAMETER (IN CM) AND SHAPE OF BASE: 10.7; circular and flat

ESTIMATED VOLUME (IN LITERS): 2.0

DECORATION (INCLUDING MOTIF AND ELEMENTS WHEN APPARENT): The upper panel of the vessel is plain, but the lower panel has an engraved scroll and semi-circle motif repeated four times around the vessel (Figure 36). The central semi-circle elements are formed from multiple closely-spaced arcing lines, and each is connected to the other by a single slanting scroll line. The upper and lower scroll fill zones have negative ovals formed by cross-hatched brackets and excised triangular areas, and negative rectangular areas formed by cross-hatched vertical bars.

PIGMENT USE AND LOCATION ON VESSEL: None

TYPE AND VARIETY (IF KNOWN): Ripley Engraved, var. Caldwell

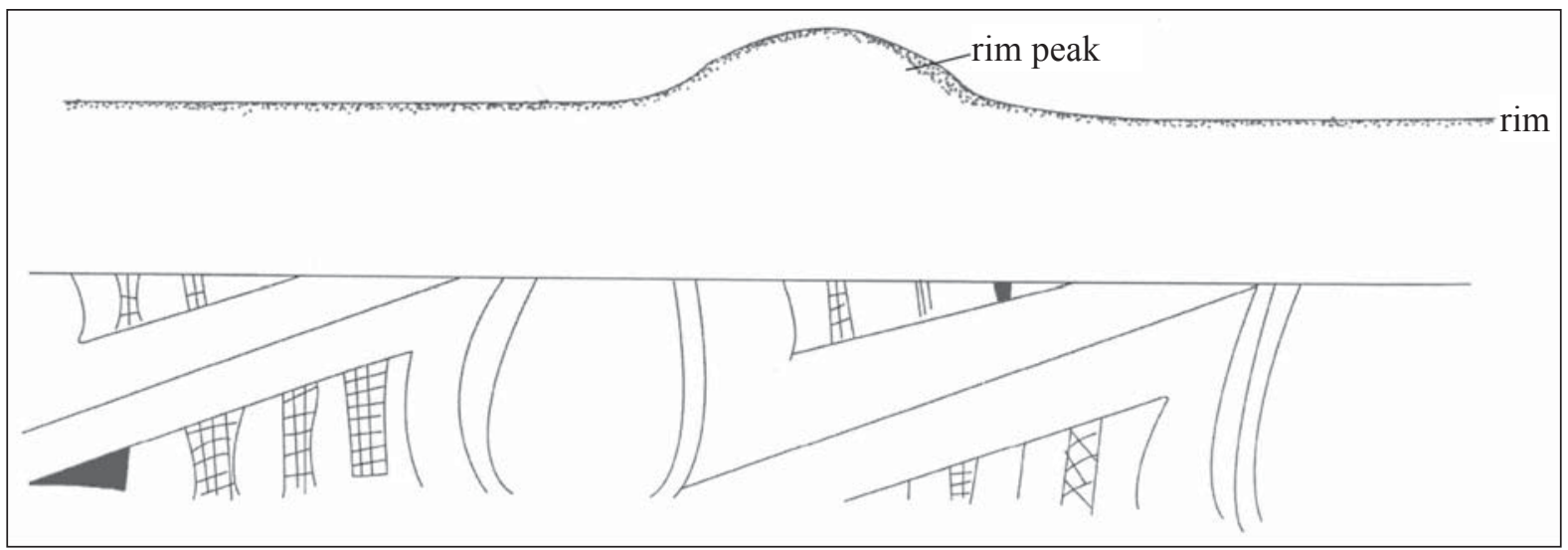

Figure 36. Decorative elements on Ripley Engraved, var. Caldwell compound bowl from the Goode site (16SA1).

As discussed above, the Bison site, Area B is a post-A.D. 1500 Caddo habitation site and cemetery (see Woodall 1969:Figure 9). A total of 15 extended burial features (and one flexed burial, Feature 1) were excavated at the site, including Feature 15 (see below). The burial features had a number of funerary offerings, including ceramic vessels, clay elbow pipes, sandstone ear spools, caches or quivers of arrow points, and clay pigments.

Feature 15 is a small burial pit (148 x $54 \mathrm{~cm}$ ), suggesting it is the interment of a child (Woodall 1969:35). The deceased was accompanied by three vessels, one of which is in the TARL collections. One vessel was a bowl with tool punctations (Woodall 1969:Figure 12t), another is a plain bottle (Woodall 1969:Figure 12s), and the third is the vessel described below, an incised beaker. 
SITE NAME OR SITE NUMBER: Bison, Area B (16SA30)

VESSEL NO.: Feature 15

VESSEL FORM: Beaker (see Woodall 1969:Figure 12u)

NON-PLASTICS AND PASTE: grog

RIM AND LIP FORM: Direct rim and a rounded, exterior folded lip

CORE COLOR: B (fired and cooled in a reducing environment)

INTERIOR SURFACE COLOR: black

EXTERIOR SURFACE COLOR: black

WALL THICKNESS (IN MM): rim, $4.4 \mathrm{~mm}$; body, $4.9 \mathrm{~mm}$; base, $7.0 \mathrm{~mm}$

INTERIOR SURFACE TREATMENT: smoothed

EXTERIOR SURFACE TREATMENT: smoothed on the lower body

HEIGHT (IN CM): 15.5

ORIFICE DIAMETER (IN CM): 11.0

DIAMETER AT BOTTOM OF RIM OR NECK (IN CM): N/A

BASE DIAMETER (IN CM) AND SHAPE OF BASE: 6.7; circular and flat

\section{ESTIMATED VOLUME \\ (IN LITERS): 1.0}

DECORATION (INCLUDING MOTIF AND ELEMENTS WHEN APPARENT): The vessel is divided into four horizontal panels by broad incised lines. The uppermost panel has a series of nested incised triangles filled with diagonal lines pitched in opposite directions (Figure 37). The lower three panels have diagonal incised lines pitched in opposite directions.

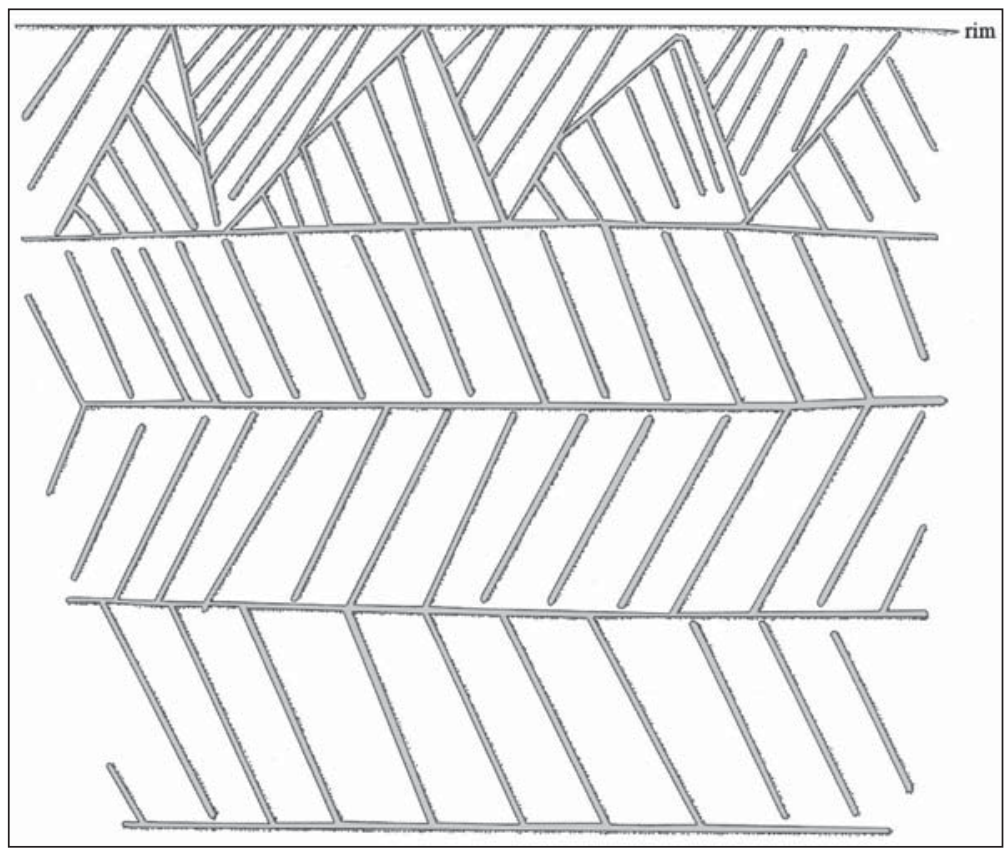

Figure 37. Decorative elements on Incised beaker from the Bison, B site (16SA30).

PIGMENT USE AND LOCATION

ON VESSEL: None

TYPE AND VARIETY (IF KNOWN): Unidentified utility ware 
The Salt Lick site (16SA37a) was a Caddo habitation site (with midden deposits) on a natural rise (Figure 38) south of La Nana bayou, a westward-flowing tributary to the Sabine River (see Figure 1). Hand and backhoe trench excavations uncovered 10 burials, six that may have been flexed (Burials 1-6) and four that were extended burials with the deceased placed in an extended supine position on the floor of the grave (Burials 7-10).

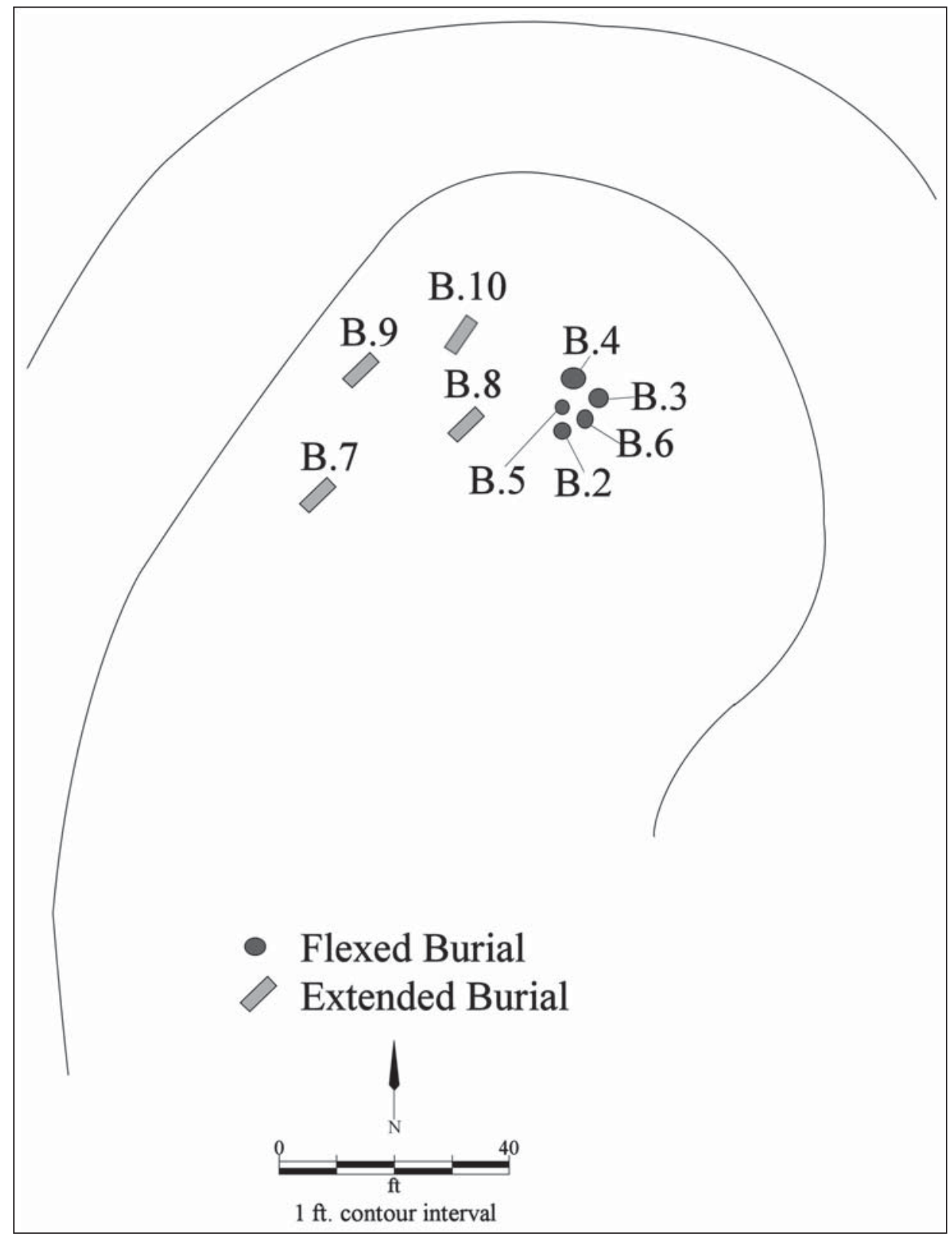

Figure 38. The location of burial features at the Salt Lick site (16SA37a).

Only two of the flexed burials had funerary offerings: a Pease Brushed-Incised jar and an engraved carinated bowl with a poorly executed design in Burial 1, and two engraved bowls in Burial 4. The engraved bowls resemble varieties of Womack Engraved and Patton Engraved (McClurkan et al. 1966:Figures 21f and 22h). The extended burials, on the other hand, had a number of funerary offerings, including ceramic vessels $(n=25)$, clay elbow pipes $(n=1)$, a quiver of Perdiz arrow points $(n=12)$, a sandstone ear spool, mussel shells $(n=2)$, and turtle shells $(n=3)$. There are currently 22 Caddo ceramic vessels in the TARL collections from the Salt Lick site. 
SITE NAME OR SITE NUMBER: Salt Lick (16SA37a)

VESSEL NO.: Feature 10, Vessel 4, Lot 121

VESSEL FORM: Bottle

NON-PLASTICS AND PASTE: bone

RIM AND LIP FORM: Direct rim and rounded lip

CORE COLOR: $\mathrm{H}$ (fired in a reducing environment and cooled in the open air)

INTERIOR SURFACE COLOR: reddish-brown

EXTERIOR SURFACE COLOR: dark grayish-brown; fire clouds on the rim, body, and base

WALL THICKNESS (IN MM): rim, $5.2 \mathrm{~mm}$

INTERIOR SURFACE TREATMENT: none

EXTERIOR SURFACE TREATMENT: smoothed

HEIGHT (IN CM): 9.7

ORIFICE DIAMETER

(IN CM): 4.1

DIAMETER AT

BOTTOM OF RIM

OR NECK (IN CM): 4.3

BASE DIAMETER (IN CM)

AND SHAPE OF BASE:

6.5; circular and flat

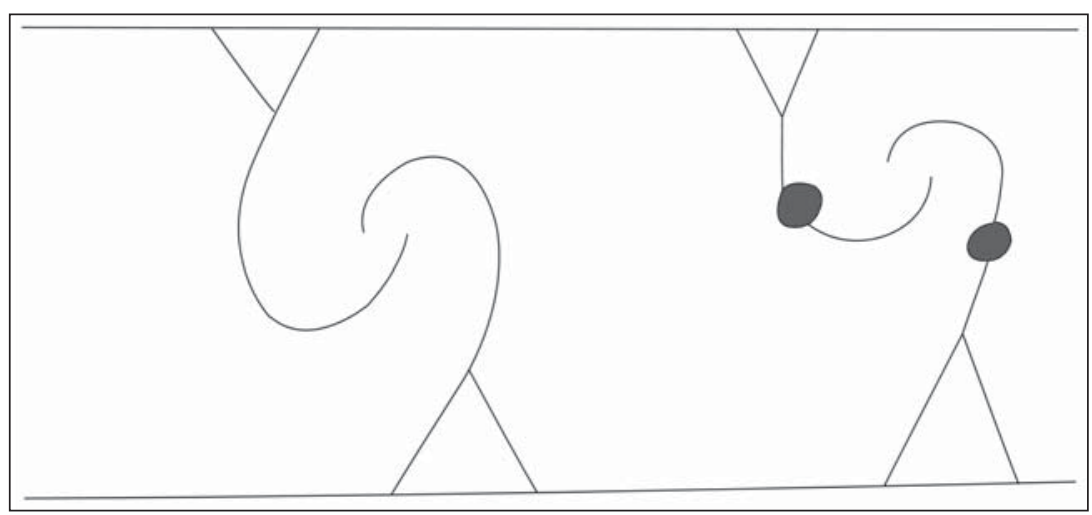

Figure 39. Decorative elements on Wilder Engraved, var. unspecified bottle from the Salt Lick site (16SA37a).

ESTIMATED VOLUME

(IN LITERS): 0.16

DECORATION (INCLUDING MOTIF AND ELEMENTS WHEN APPARENT): The vessel body has single horizontal engraved lines at the top of the body and near the vessel body. The panel has five sets of vertical scrolls with hooked arm elements (Figure 39); one of the scrolls has small excised circles on the upper and lower scroll arms. The vertical scrolls begin from upper and lower engraved pendant triangles.

PIGMENT USE AND LOCATION ON VESSEL: None

TYPE AND VARIETY (IF KNOWN): Wilder Engraved, var. unspecified 
SITE NAME OR SITE NUMBER: Salt Lick (16SA37a)

VESSEL NO.: Feature 7, Vessel 2, Lot 114

VESSEL FORM: Bowl (McClurkan et al. 1966:Figure 21f)

NON-PLASTICS AND PASTE: grog

RIM AND LIP FORM: Direct rim and flat lip

CORE COLOR: F (fired in a reducing environment and cooled in the open air)

INTERIOR SURFACE COLOR: reddish-brown; fire clouds on the body and base

EXTERIOR SURFACE COLOR: reddish-brown; fire clouds on the rim and body; organic residue on the vessel body

WALL THICKNESS (IN MM): rim, $5.9 \mathrm{~mm}$; body, $5.0 \mathrm{~mm}$; base, $8.8 \mathrm{~mm}$

INTERIOR SURFACE TREATMENT: smoothed

EXTERIOR SURFACE TREATMENT: smoothed

HEIGHT (IN CM): 13.5

ORIFICE DIAMETER (IN CM): 12.8

DIAMETER AT BOTTOM OF RIM OR NECK (IN CM): 15.0

BASE DIAMETER (IN CM) AND SHAPE OF BASE: 9.0; circular and flat

ESTIMATED VOLUME (IN LITERS): 0.7

DECORATION (INCLUDING MOTIF AND ELEMENTS WHEN APPARENT): The rim of the vessel has a single horizontal engraved line below the rim as well as a continuous series of cross-hatched engraved pendant triangles (Figure 40). The rim is broken, but there are at least 15 pendant triangles around the vessel rim.

PIGMENT USE AND LOCATION ON VESSEL: None

TYPE AND VARIETY (IF KNOWN): Unidentified fine ware

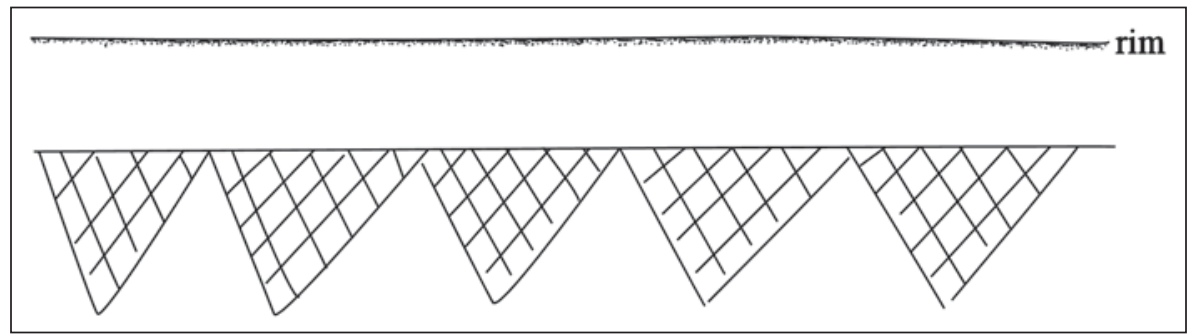

Figure 40. Decorative elements on an engraved bowl from the Salt Lick site. 
SITE NAME OR SITE NUMBER: Salt Lick (16SA37a)

VESSEL NO.: Feature 5, Vessel 5, Lot 111

VESSEL FORM: Jar with short rim

NON-PLASTICS AND PASTE: bone

RIM AND LIP FORM: Everted rim and flat lip

CORE COLOR: B (fired and cooled in a reducing environment)

INTERIOR SURFACE COLOR: dark grayish-brown

EXTERIOR SURFACE COLOR: black

WALL THICKNESS (IN MM): rim, 7.9 mm

INTERIOR SURFACE TREATMENT: smoothed

EXTERIOR SURFACE TREATMENT: none

HEIGHT (IN CM): 8.5

ORIFICE DIAMETER

(IN CM): 10.5

DIAMETER AT BOTTOM

OF RIM OR NECK (IN CM): 8.6

BASE DIAMETER

(IN CM) AND SHAPE OF BASE:

circular and flat

ESTIMATED VOLUME

(IN LITERS): 0.53

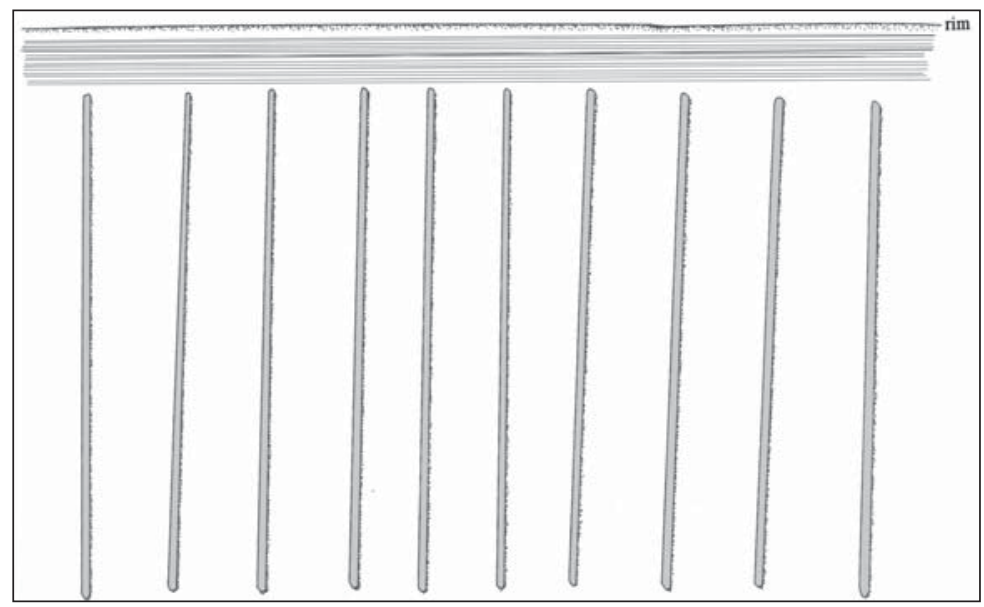

DECORATION (INCLUDING

MOTIF AND ELEMENTS

Figure 41. Decorative elements on Karnack Brushed-Incised jar from the Salt Lick site (16SA37a).

WHEN APPARENT): The short

rim has horizontal brushing marks (Figure 41). The vessel body has a continuous series of vertical incised lines that extend from the rim-body juncture to within $10 \mathrm{~mm}$ of the vessel base.

PIGMENT USE AND LOCATION ON VESSEL: None

TYPE AND VARIETY (IF KNOWN): Karnack Brushed-Incised 
SITE NAME OR SITE NUMBER: Salt Lick (16SA37a)

VESSEL NO.: Feature 12, Vessel 4, Lot 132

VESSEL FORM: Bottle with a short and straight neck

NON-PLASTICS AND PASTE: bone

RIM AND LIP FORM: Everted rim and rounded lip

CORE COLOR: $\mathrm{G}$ (fired in a reducing environment and cooled in the open air)

INTERIOR SURFACE COLOR: dark grayish-brown

EXTERIOR SURFACE COLOR: reddish-brown; fire clouds on the rim, body, and base

WALL THICKNESS (IN MM): rim, $5.4 \mathrm{~mm}$

INTERIOR SURFACE TREATMENT: none

EXTERIOR SURFACE TREATMENT: none

HEIGHT (IN CM): 8.5

ORIFICE DIAMETER (IN CM): 3.2

DIAMETER AT BOTTOM OF RIM

OR NECK (IN CM): 3.3; maximum

body diameter is $5.6 \mathrm{~cm}$

BASE DIAMETER (IN CM) AND

SHAPE OF BASE: 3.9;

circular and flat

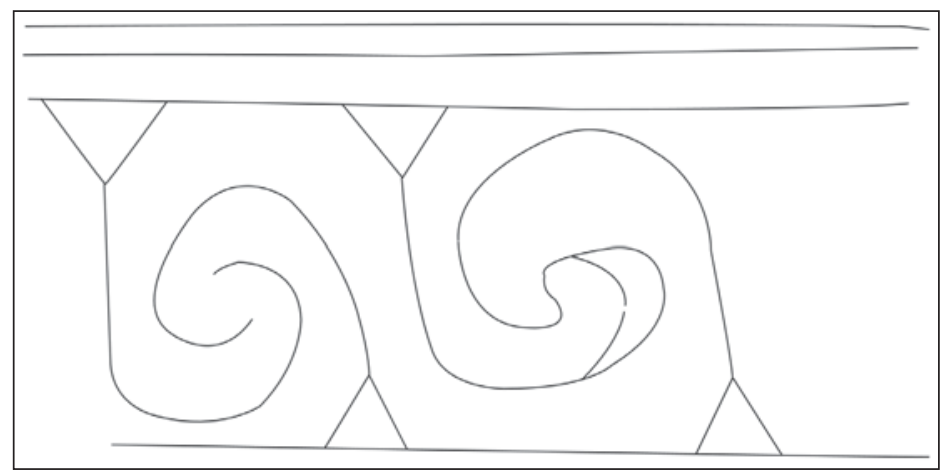

ESTIMATED VOLUME

(IN LITERS): 0.13

Figure 42. Decorative elements on Wilder Engraved, var. unspecified bottle from the Salt Lick site.

DECORATION (INCLUDING MOTIF AND ELEMENTS WHEN APPARENT): There are three horizontal engraved lines at the top of the vessel body and one horizontal engraved line near the vessel base. The engraved panel on the body consists of three upper and lower hooked arm scrolls; in two cases the scrolls do not meet, but in the third case they do meet, and there is an extra engraved line at the intersection, widening the scroll accordingly (Figure 42). The upper and lower scrolls begin at the apex of large open pendant triangles.

PIGMENT USE AND LOCATION ON VESSEL: None

TYPE AND VARIETY (IF KNOWN): Wilder Engraved, var. unspecified 
SITE NAME OR SITE NUMBER: Salt Lick (16SA37a)

VESSEL NO.: Lot 144

VESSEL FORM: Carinated bowl

NON-PLASTICS AND PASTE: bone

RIM AND LIP FORM: Direct rim and rounded lip

CORE COLOR: F (fired in a reducing environment and cooled in the open air)

INTERIOR SURFACE COLOR: dark reddish-brown; fire clouds on the rim, body, and base

EXTERIOR SURFACE COLOR: reddish-brown; fire clouds on the rim, body, and base

WALL THICKNESS (IN MM): rim, $5.6 \mathrm{~mm}$; body, $5.5 \mathrm{~mm}$

INTERIOR SURFACE TREATMENT: smoothed

EXTERIOR SURFACE TREATMENT: smoothed

HEIGHT (IN CM): 6.0

ORIFICE DIAMETER (IN CM): 11.7

DIAMETER AT BOTTOM OF RIM OR NECK (IN CM): 9.5

BASE DIAMETER (IN CM) AND SHAPE OF BASE: 3.9; circular and flat

ESTIMATED VOLUME (IN LITERS): 0.42

DECORATION (INCLUDING MOTIF AND ELEMENTS WHEN APPARENT): There are two horizontal engraved lines at the top of the rim panel, and the rim panel itself has a unique but poorly executed series of engraved elements (Figure 43). There are circles, semi-circles, vertical lines, diagonal lines, and various combinations of these elements, but these decorative elements have no apparent pattern of repetitive series of elements.

PIGMENT USE AND LOCATION ON VESSEL: None

TYPE AND VARIETY (IF KNOWN): Unidentified fine ware

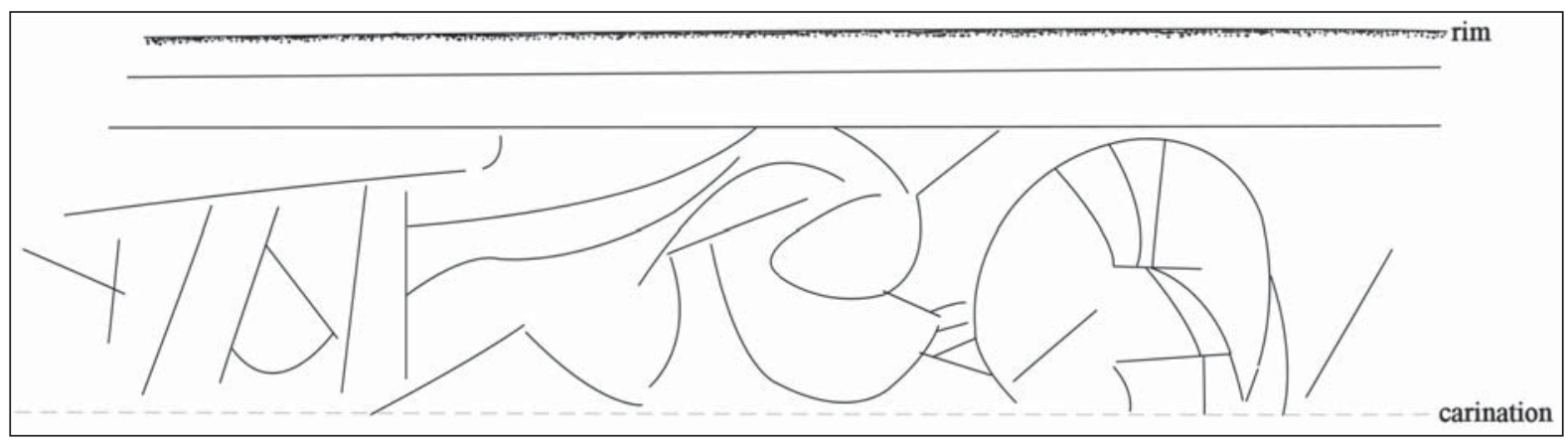

Figure 43. Decorative elements on engraved carinated bowl from the Salt Lick site. 
SITE NAME OR SITE NUMBER: Salt Lick (16SA37a)

VESSEL NO.: Feature 5, Vessel 3, Lot 109

VESSEL FORM: Carinated bowl

NON-PLASTICS AND PASTE: bone

RIM AND LIP FORM: Direct rim and rounded, exterior folded lip

CORE COLOR: $\mathrm{G}$ (fired in a reducing environment and cooled in the open air)

INTERIOR SURFACE COLOR: grayish-brown

EXTERIOR SURFACE COLOR: reddish-brown; fire clouds on the rim, body, and base

WALL THICKNESS (IN MM): rim, $5.4 \mathrm{~mm}$

INTERIOR SURFACE TREATMENT: smoothed

EXTERIOR SURFACE TREATMENT: smoothed

HEIGHT (IN CM): 6.8

ORIFICE DIAMETER (IN CM): 11.5

DIAMETER AT BOTTOM OF RIM OR NECK (IN CM): 11.4

BASE DIAMETER (IN CM) AND SHAPE OF BASE: 3.5; circular and rounded

ESTIMATED VOLUME (IN LITERS): 0.47

DECORATION (INCLUDING MOTIF AND ELEMENTS WHEN APPARENT): The rim panel has three sets of engraved horizontal interlocking scrolls (cf. Thurmond 1990:Figure 6); the scrolls are interlocked by excised brackets. The sets of scroll motifs are divided by large excised brackets (Figure 44).

PIGMENT USE AND LOCATION ON VESSEL: None

TYPE AND VARIETY (IF KNOWN): Ripley Engraved, var. Pilgrims (see Perttula et al. 2012:Figure 4g), but not the very different var. Pilgrim's defined and illustrated by Fields et al. (2014:Table 8.6)

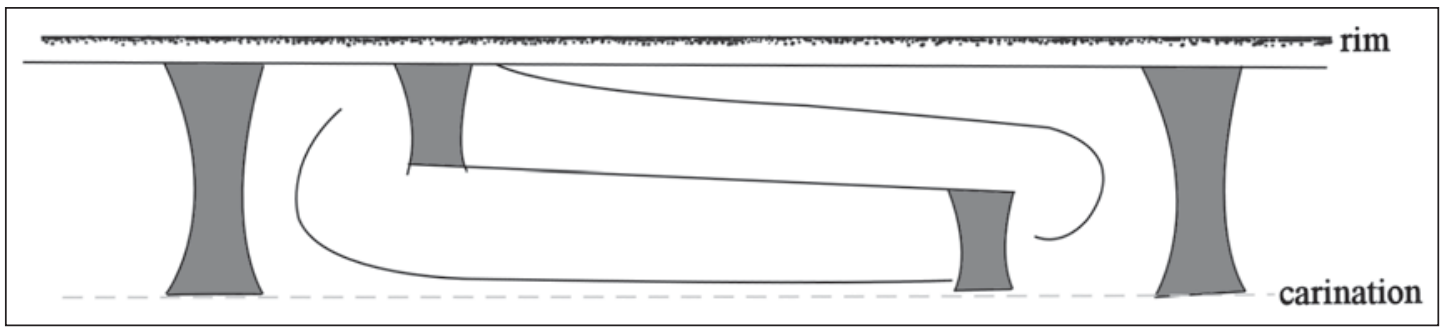

Figure 44. Decorative elements on Ripley Engraved, var. Pilgrims carinated bowl from the Salt Lick site (16SA37a). 
SITE NAME OR SITE NUMBER: Salt Lick (16SA37a)

VESSEL NO.: Feature 5, Vessel 1, Lot 107

VESSEL FORM: Bottle

NON-PLASTICS AND PASTE: bone

RIM AND LIP FORM: Direct rim, but missing lip

CORE COLOR: B (fired and cooled in a reducing environment)

INTERIOR SURFACE COLOR: black

EXTERIOR SURFACE COLOR: black

WALL THICKNESS (IN MM): neck, $4.3 \mathrm{~mm}$

INTERIOR SURFACE TREATMENT: none

EXTERIOR SURFACE TREATMENT: smoothed

HEIGHT (IN CM): 8.7+

ORIFICE DIAMETER (IN CM): 3.4

DIAMETER AT BOTTOM OF RIM OR

NECK (IN CM): $4.5 ; 8.1 \mathrm{~cm}$ is the

maximum body diameter

BASE DIAMETER (IN CM) AND

SHAPE OF BASE: 6.8; circular and flat

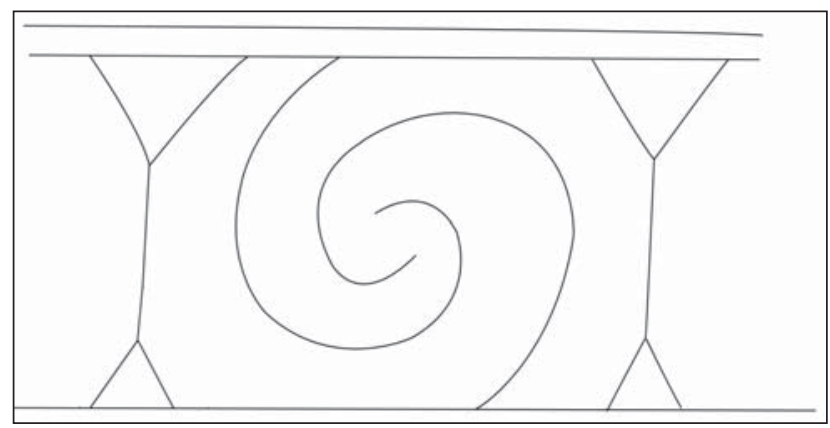

Figure 45. Decorative elements on Wilder Engraved, var. unspecified bottle from the Salt Lick site.

ESTIMATED VOLUME

(IN LITERS): 0.24

DECORATION (INCLUDING MOTIF AND ELEMENTS WHEN APPARENT): The panel on the vessel body is defined by single upper and lower horizontal engraved lines. There are four repeating sets of upper and lower hooked arm scrolls that do not touch (Figure 45). The scrolls are divided by vertical lines and upper and lower open pendant triangles.

PIGMENT USE AND LOCATION ON VESSEL: None

TYPE AND VARIETY (IF KNOWN): Wilder Engraved, var. unspecified 
SITE NAME OR SITE NUMBER: Salt Lick (16SA37a)

VESSEL NO.: Feature 7, Vessel 1, Lot 113

VESSEL FORM: Bowl with a globular body

NON-PLASTICS AND PASTE: bone and grog

RIM AND LIP FORM: Everted rim and rounded lip

CORE COLOR: $F$ (fired in a reducing environment and cooled in the open air)

INTERIOR SURFACE COLOR: reddish-brown; fire clouds on the rim and body

EXTERIOR SURFACE COLOR: reddish-brown; fire clouds on the rim, body, and base

WALL THICKNESS (IN MM): rim, $4.6 \mathrm{~mm}$; body, $5.4 \mathrm{~mm}$

INTERIOR SURFACE TREATMENT: smoothed

EXTERIOR SURFACE TREATMENT: burnished

HEIGHT (IN CM): 7.9

ORIFICE DIAMETER (IN CM): 18.9

DIAMETER AT BOTTOM OF RIM OR

NECK (IN CM): 15.5

BASE DIAMETER (IN CM)

AND SHAPE OF BASE: 9.5;

circular and rounded

ESTIMATED VOLUME

(IN LITERS): 0.9

DECORATION (INCLUDING

MOTIF AND ELEMENTS WHEN

APPARENT): The rim has five

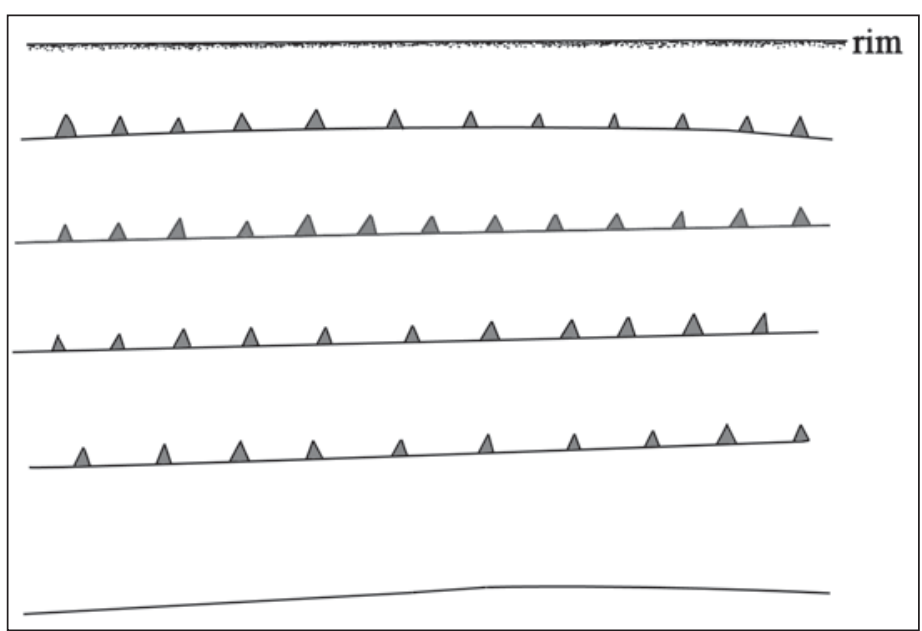

Figure 46. Decorative elements on cf. Patton Engraved, var. Allen globular bowl from the Salt Lick site (16SA37a). horizontal engraved lines, and the uppermost four lines have excised tick marks that point upwards towards the vessel rim (Figure 46); the fifth line has no tick marks. Between the fourth and fifth horizontal engraved lines is an unusual horizontal ridge element.

PIGMENT USE AND LOCATION ON VESSEL: None

TYPE AND VARIETY (IF KNOWN): cf. Patton Engraved, var. Allen (Perttula et al. 2011:Figure 6-66) 
SITE NAME OR SITE NUMBER: Salt Lick (16SA37a)

VESSEL NO.: Feature 10, Vessel 1, Lot 118

VESSEL FORM: Jar with very short rim

NON-PLASTICS AND PASTE: grog

RIM AND LIP FORM: Everted rim and flattened lip

CORE COLOR: $\mathrm{H}$ (fired in a reducing environment and cooled in the open air)

INTERIOR SURFACE COLOR: brown; fire clouds on the body

EXTERIOR SURFACE COLOR: black; fire clouds on the body and base; organic residue on the vessel body

WALL THICKNESS (IN MM): rim, $7.8 \mathrm{~mm}$; body, $6.2 \mathrm{~mm}$

INTERIOR SURFACE TREATMENT: smoothed

EXTERIOR SURFACE TREATMENT: none

HEIGHT (IN CM): 19.5

ORIFICE DIAMETER (IN CM): 13.5

DIAMETER AT BOTTOM OF RIM OR NECK (IN CM): 13.0

BASE DIAMETER (IN CM) AND SHAPE OF BASE: 6.3; circular and flat

ESTIMATED VOLUME (IN LITERS): 2.4

DECORATION (INCLUDING MOTIF AND ELEMENTS WHEN APPARENT): The rim of the vessel is plain, but the vessel body has vertical brushed-incised marks and lines that extend from the rim-body juncture to within $20 \mathrm{~mm}$ of the vessel base.

PIGMENT USE AND LOCATION ON VESSEL: None

TYPE AND VARIETY (IF KNOWN): Karnack Brushed-Incised 
SITE NAME OR SITE NUMBER: Salt Lick (16SA37a)

VESSEL NO.: Feature 13, Vessel 1, Lot 136

VESSEL FORM: Olla with a short neck (see McClurkan et al. 1966:Figure 19b)

NON-PLASTICS AND PASTE: bone

RIM AND LIP FORM: Everted rim and a rounded, exterior folded lip

CORE COLOR: $\mathrm{G}$ (fired in a reducing environment and cooled in the open air)

INTERIOR SURFACE COLOR: grayish-brown; fire clouds on the body and base

EXTERIOR SURFACE COLOR: reddish-brown; fire clouds on the neck, body, and base

WALL THICKNESS (IN MM): neck, $4.5 \mathrm{~mm}$; body, $5.0 \mathrm{~mm}$; base, $8.9 \mathrm{~mm}$

INTERIOR SURFACE TREATMENT: none

EXTERIOR SURFACE TREATMENT: smoothed

HEIGHT (IN CM): 34.0

ORIFICE DIAMETER (IN CM): 7.7

DIAMETER AT BOTTOM OF RIM OR NECK (IN CM): 11.6; maximum body diameter of $28.5 \mathrm{~cm}$

BASE DIAMETER (IN CM) AND SHAPE OF BASE: 8.1; circular and flat

ESTIMATED VOLUME (IN LITERS): 2.2

DECORATION (INCLUDING MOTIF AND ELEMENTS WHEN APPARENT): There is a single horizontal engraved line at the juncture of the neck and the vessel body.

PIGMENT USE AND LOCATION ON VESSEL: None

TYPE AND VARIETY (IF KNOWN): Unidentified fine ware 
SITE NAME OR SITE NUMBER: Salt Lick (16SA37a)

VESSEL NO.: Feature 12, Vessel 5, Lot 134

VESSEL FORM: Jar with very short rim

NON-PLASTICS AND PASTE: bone

RIM AND LIP FORM: Everted rim and rounded lip

CORE COLOR: F (fired in a reducing environment and cooled in the open air)

INTERIOR SURFACE COLOR: reddish-brown; fire clouds on the rim, body, and base

EXTERIOR SURFACE COLOR: reddish-brown; fire clouds on the rim, body, and base; organic residue on the vessel body

WALL THICKNESS (IN MM): rim, $5.8 \mathrm{~mm}$; body, $6.0 \mathrm{~mm}$

INTERIOR SURFACE TREATMENT: smoothed

EXTERIOR SURFACE TREATMENT: smoothed on the lower body

HEIGHT (IN CM): 18.5

ORIFICE DIAMETER (IN CM): 13.6

DIAMETER AT BOTTOM OF RIM OR NECK (IN CM): 13.3

BASE DIAMETER (IN CM) AND SHAPE OF BASE: 7.0; circular and flat

ESTIMATED VOLUME (IN LITERS): 2.2

DECORATION (INCLUDING MOTIF AND ELEMENTS WHEN APPARENT): the rim has horizontal brushing marks, and the vessel body has vertical brushing marks that extend from the rim-body juncture to within $25 \mathrm{~mm}$ of the base.

PIGMENT USE AND LOCATION ON VESSEL: None

TYPE AND VARIETY (IF KNOWN): Karnack Brushed-Incised 
SITE NAME OR SITE NUMBER: Salt Lick (16SA37a)

VESSEL NO.: Feature 10, Vessel 5

VESSEL FORM: Bowl

NON-PLASTICS AND PASTE: bone

RIM AND LIP FORM: Direct rim and rounded, exterior folded lip

CORE COLOR: A (fired and cooled in an oxidizing environment)

INTERIOR SURFACE COLOR: reddish-brown; fire clouds on the rim

EXTERIOR SURFACE COLOR: reddish-brown; fire clouds on the body

WALL THICKNESS (IN MM): rim, $5.0 \mathrm{~mm}$; body, $5.2 \mathrm{~mm}$

INTERIOR SURFACE TREATMENT: smoothed

EXTERIOR SURFACE TREATMENT: smoothed

HEIGHT (IN CM): 5.5

ORIFICE DIAMETER (IN CM): 18.0

DIAMETER AT BOTTOM OF RIM OR NECK (IN CM): N/A

BASE DIAMETER (IN CM) AND SHAPE OF BASE: 6.0; circular and flat

ESTIMATED VOLUME (IN LITERS): 0.4

DECORATION (INCLUDING MOTIF AND ELEMENTS WHEN APPARENT): The vessel has only a single broad horizontal engraved line on its interior, $43 \mathrm{~mm}$ below the vessel lip.

PIGMENT USE AND LOCATION ON VESSEL: None

TYPE AND VARIETY (IF KNOWN): Unidentified fine ware 
SITE NAME OR SITE NUMBER: Salt Lick (16SA37a)

VESSEL NO.: Feature 13, Vessel 3, Lot 138

VESSEL FORM: Carinated bowl

NON-PLASTICS AND PASTE: bone

RIM AND LIP FORM: Inverted rim and a rounded, exterior folded lip

CORE COLOR: F (fired in a reducing environment and cooled in the open air)

INTERIOR SURFACE COLOR: reddish-brown

EXTERIOR SURFACE COLOR: reddish-brown; fire clouds on the rim, body, and base

WALL THICKNESS (IN MM): rim, 6.4 mm; body, $8.2 \mathrm{~mm}$

INTERIOR SURFACE TREATMENT: smoothed

EXTERIOR SURFACE TREATMENT: smoothed

HEIGHT (IN CM): 13.5

ORIFICE DIAMETER (IN CM): 22.1

DIAMETER AT BOTTOM OF RIM OR NECK (IN CM): 23.0

BASE DIAMETER (IN CM) AND SHAPE OF BASE: 8.5; circular and flat

ESTIMATED VOLUME (IN LITERS): 2.7

DECORATION (INCLUDING MOTIF AND ELEMENTS WHEN APPARENT): Plain

PIGMENT USE AND LOCATION ON VESSEL: None

TYPE AND VARIETY (IF KNOWN): Unidentified plain ware 
SITE NAME OR SITE NUMBER: Salt Lick (16SA37a)

VESSEL NO.: general collections, 1964-1965 excavations (McClurkan et al. 1966)

VESSEL FORM: Carinated bowl

NON-PLASTICS AND PASTE: bone

RIM AND LIP FORM: Direct rim and rounded, exterior folded lip

CORE COLOR: $\mathrm{F}$ (fired in a reducing environment and cooled in the open air)

INTERIOR SURFACE COLOR: reddish-brown; fire clouds on the body and base

EXTERIOR SURFACE COLOR: reddish-brown; fire clouds on the rim, body, and base

WALL THICKNESS (IN MM): rim, $4.9 \mathrm{~mm}$; body, $6.3 \mathrm{~mm}$; base, $7.4 \mathrm{~mm}$

INTERIOR SURFACE TREATMENT: smoothed

EXTERIOR SURFACE TREATMENT: smoothed

HEIGHT (IN CM): 8.3

ORIFICE DIAMETER (IN CM): 18.0

DIAMETER AT BOTTOM OF RIM OR NECK (IN CM): 18.0

BASE DIAMETER (IN CM) AND SHAPE OF BASE: 7.0; circular and flat

ESTIMATED VOLUME (IN LITERS): 0.9

DECORATION (INCLUDING MOTIF AND ELEMENTS WHEN APPARENT): The rim has four horizontal engraved scrolls divided by excised brackets (Figure 47). The scrolls have rounded ends. Above one of the straight scrolls is a single excised pendant triangle.

PIGMENT USE AND LOCATION ON VESSEL: None

TYPE AND VARIETY (IF KNOWN): Ripley Engraved, var. Gandy

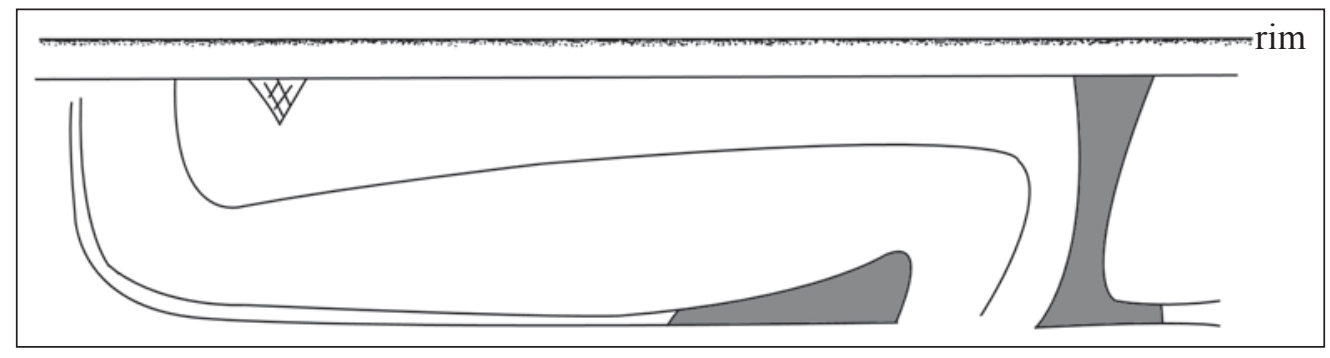

Figure 47. Decorative elements on Ripley Engraved, var. Gandy carinated bowl from the Salt Lick site. 
SITE NAME OR SITE NUMBER: Salt Lick (16SA37a)

VESSEL NO.: Feature 6, Vessel 2, Lot 108 (see McClurkan et al. 1966:Figure 20b)

VESSEL FORM: Jar with four rim peaks

NON-PLASTICS AND PASTE: bone and a sandy paste

RIM AND LIP FORM: Direct rim and a rounded, exterior folded lip

CORE COLOR: $F$ (fired in a reducing environment and cooled in the open air)

INTERIOR SURFACE COLOR: reddish-brown; fire clouds on the rim and body

EXTERIOR SURFACE COLOR: brown; fire clouds on the rim, body, and base

WALL THICKNESS (IN MM): body, $6.3 \mathrm{~mm}$; base, $9.6 \mathrm{~mm}$

INTERIOR SURFACE TREATMENT: smoothed

EXTERIOR SURFACE TREATMENT: none

HEIGHT (IN CM): 11.0

ORIFICE DIAMETER

(IN CM): 12.0

DIAMETER AT BOTTOM OF RIM OR NECK

(IN CM): 11.0

BASE DIAMETER (IN CM) AND SHAPE

OF BASE: 7.5; circular and flat

ESTIMATED VOLUME (IN LITERS): 0.8

DECORATION (INCLUDING MOTIF AND ELEMENTS WHEN APPARENT): The rim

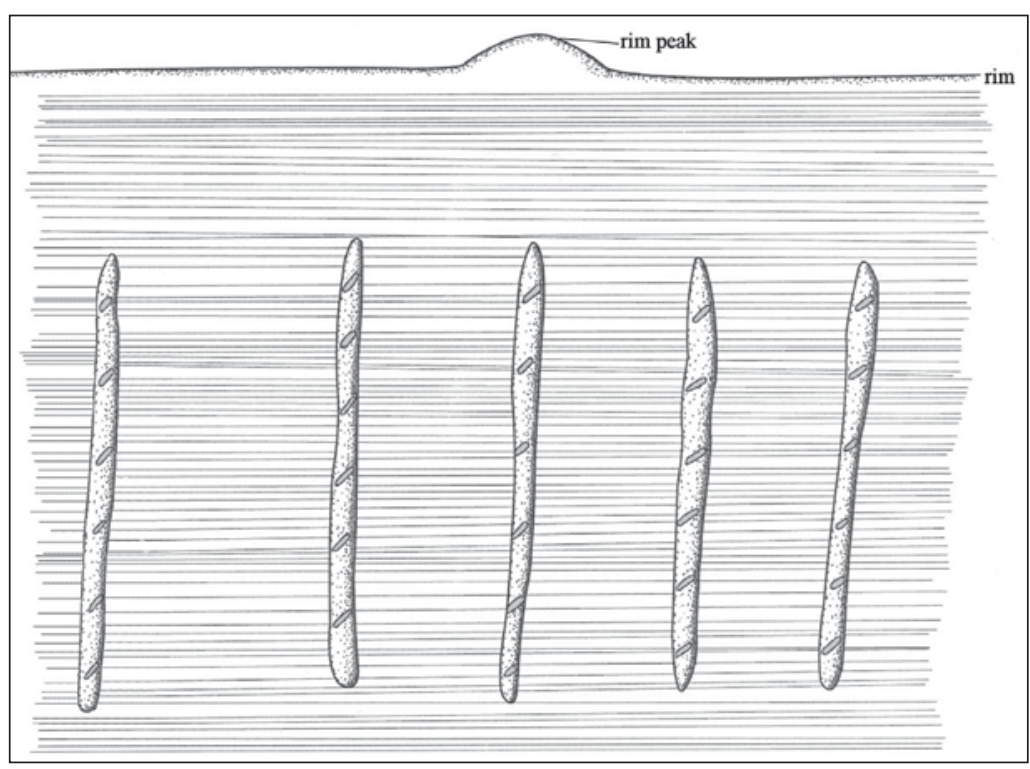

Figure 48. Decorative elements on Pease Brushed-Incised jar from the Salt Lick site (16SA37a). is decorated with horizontal brushing marks. The vessel body is divided into at least 10 vertical panels by vertical appliqued fillets (Figure 48). The panels are filled with horizontal brushing marks, and the brushing was applied after the appliqued fillets had been attached to the vessel body.

PIGMENT USE AND LOCATION ON VESSEL: None

TYPE AND VARIETY (IF KNOWN): Pease Brushed-Incised 
SITE NAME OR SITE NUMBER: Salt Lick (16SA37a)

VESSEL NO.: Lot 143

VESSEL FORM: Jar

NON-PLASTICS AND PASTE: grog

RIM AND LIP FORM: Everted rim and rounded lip

CORE COLOR: $\mathrm{G}$ (fired in a reducing environment and cooled in the open air)

INTERIOR SURFACE COLOR: grayish-brown

EXTERIOR SURFACE COLOR: reddish-brown; fire clouds on the rim, body, and base

WALL THICKNESS (IN MM): rim, $4.7 \mathrm{~mm}$; body, $5.6 \mathrm{~mm}$

INTERIOR SURFACE TREATMENT: none

EXTERIOR SURFACE TREATMENT: none

HEIGHT (IN CM): 11.7

ORIFICE DIAMETER (IN CM): 7.5

DIAMETER AT BOTTOM OF RIM OR NECK (IN CM): 6.7

BASE DIAMETER (IN CM) AND SHAPE OF BASE: 4.5; circular and flat

ESTIMATED VOLUME (IN LITERS): 0.53

DECORATION (INCLUDING MOTIF AND ELEMENTS WHEN APPARENT): The vessel rim is decorated with horizontal brushing marls. The vessel body is divided into seven vertical panels by vertical incised lines (Figure 49). The vertical panels are filled with diagonal incised lines pitched in alternate directions from panel to panel.

PIGMENT USE AND LOCATION ON VESSEL: None

TYPE AND VARIETY (IF KNOWN): Pease Brushed-Incised (see Suhm and Jelks 1962:Plate 60k)

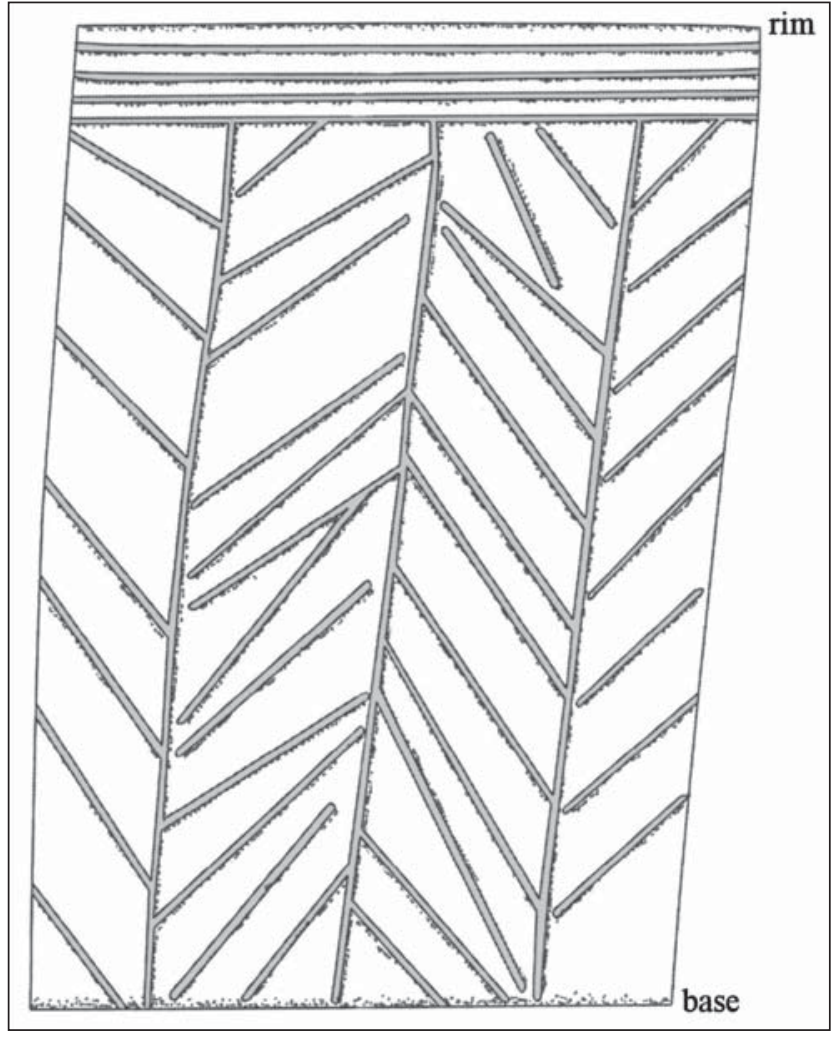

Figure 49. Decorative elements on Pease Brushed-Incised jar from the Salt Lick site. 
SITE NAME OR SITE NUMBER: Salt Lick (16SA37a)

VESSEL NO.: Feature 12, Lot 130

VESSEL FORM: Bottle with long and bulbous neck

NON-PLASTICS AND PASTE: bone

RIM AND LIP FORM: Direct rim and a rounded, exterior folded lip

CORE COLOR: $\mathrm{G}$ (fired in a reducing environment and cooled in the open air)

INTERIOR SURFACE COLOR: dark gray

EXTERIOR SURFACE COLOR: reddish-brown; fire clouds on the neck, body, and base

WALL THICKNESS (IN MM): rim, $5.6 \mathrm{~mm}$; body, $5.4 \mathrm{~mm}$

INTERIOR SURFACE TREATMENT: none

EXTERIOR SURFACE TREATMENT: none

HEIGHT (IN CM): 11.6; neck

height, $5.6 \mathrm{~cm}$

ORIFICE DIAMETER

(IN CM): 3.0

DIAMETER AT BOTTOM OF

RIM OR NECK (IN CM): 2.9

BASE DIAMETER (IN CM)

AND SHAPE OF BASE: 4.3;

circular and rounded

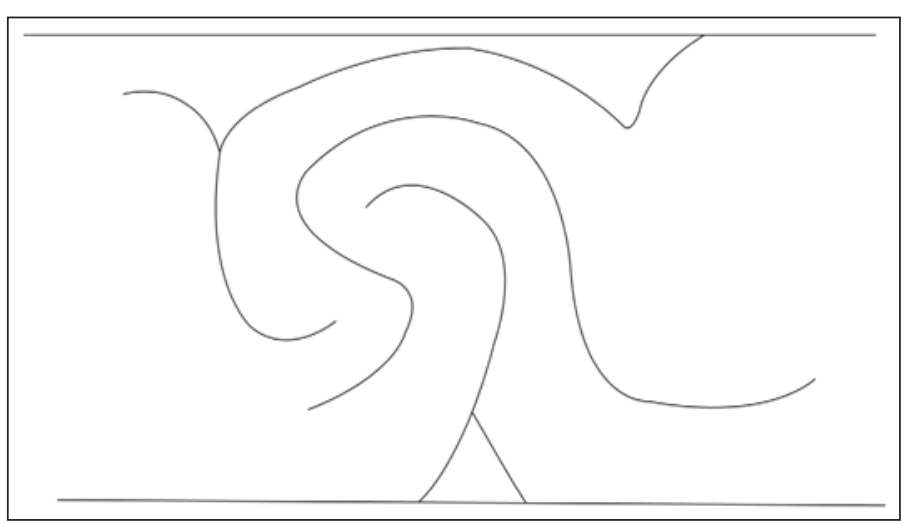

ESTIMATED VOLUME

(IN LITERS): 0.2

Figure 50. Decorative elements on cf. Wilder Engraved bottle from the Salt Lick site (16SA37a).

DECORATION (INCLUDING MOTIF AND ELEMENTS WHEN APPARENT): The vessel body has curvilinear and vertical engraved hooked arm scrolls that are repeated four times around the vessel (Figure 50). The scrolls originate from the apex of upper and lower large open pendant triangles.

PIGMENT USE AND LOCATION ON VESSEL: None

TYPE AND VARIETY (IF KNOWN): cf. Wilder Engraved 
SITE NAME OR SITE NUMBER: Salt Lick (16SA37a)

VESSEL NO.: Feature 13, Vessel 7, Lot 142

VESSEL FORM: Carinated bowl (see McClurkan et al. 1966:Figure 19a)

NON-PLASTICS AND PASTE: grog

RIM AND LIP FORM: Inverted rim and a rounded, exterior folded lip

CORE COLOR: $F$ (fired in a reducing environment and cooled in the open air)

INTERIOR SURFACE COLOR: light brown

EXTERIOR SURFACE COLOR: brown; fire clouds on the rim and body

WALL THICKNESS (IN MM): rim, 5.4 mm; body, $5.6 \mathrm{~mm}$

INTERIOR SURFACE TREATMENT: smoothed

EXTERIOR SURFACE TREATMENT: burnished

HEIGHT (IN CM):

rim height, $4.0 \mathrm{~cm}$

ORIFICE DIAMETER

(IN CM): 25.0

DIAMETER AT BOTTOM

OF RIM OR NECK

(IN CM): 25.8

BASE DIAMETER (IN CM)

AND SHAPE OF BASE: N/A

ESTIMATED VOLUME

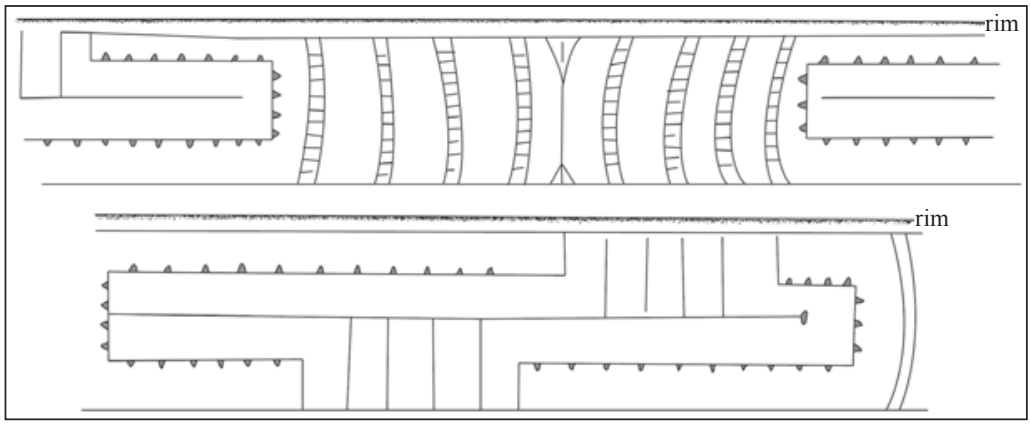

Figure 51. Decorative elements on Glassell Engraved carinated bowl from the Salt Lick site (16SA37a).

(IN LITERS): N/A

DECORATION (INCLUDING MOTIF AND ELEMENTS WHEN APPARENT): The rim is divided into four panels with two different and alternating engraved motifs. The first motif, in two panels, consists of eight near vertical narrow zones with horizontal hatched lines; the zones are divided by a vertical line with upper and lower hatched pendant triangles (Figure 51). The second motif in the other two panels has a rectilinear engraved zone filled with a single horizontal line and four upper and lower vertical lines. Four sides of the rectilinear engraved zone have excised tick marks.

PIGMENT USE AND LOCATION ON VESSEL: None

TYPE AND VARIETY (IF KNOWN): Glassell Engraved 
SITE NAME OR SITE NUMBER: Salt Lick (16SA37a)

VESSEL NO.: Feature 12, Vessel 3, Lot 131

VESSEL FORM: Bowl (see McClurkan et al. 1966:Figure 23d)

NON-PLASTICS AND PASTE: bone and hematite

RIM AND LIP FORM: Direct rim and rounded, exterior folded lip

CORE COLOR: $F$ (fired in a reducing environment and cooled in the open air)

INTERIOR SURFACE COLOR: light brown; fire clouds on the rim and body

EXTERIOR SURFACE COLOR: reddish-brown; fire clouds on the rim, body, and base

WALL THICKNESS (IN MM): rim, $5.1 \mathrm{~mm}$

INTERIOR SURFACE TREATMENT: none

EXTERIOR SURFACE TREATMENT: smoothed

HEIGHT (IN CM): 4.0

ORIFICE DIAMETER (IN CM): 10.0

DIAMETER AT BOTTOM OF RIM OR NECK (IN CM): N/A

BASE DIAMETER (IN CM) AND SHAPE OF BASE: 4.6; circular and flat

ESTIMATED VOLUME (IN LITERS): 0.16

DECORATION (INCLUDING MOTIF AND ELEMENTS WHEN APPARENT): The vessel has a panel defined by single upper and lower horizontal engraved lines; the lower engraved line is just above the base. The body is decorated with four repeating tear-drop elements divided by excised and flat-topped brackets and large open pendant triangles (Figure 52).

PIGMENT USE AND LOCATION ON VESSEL: None

TYPE AND VARIETY (IF KNOWN): Unidentified fine ware

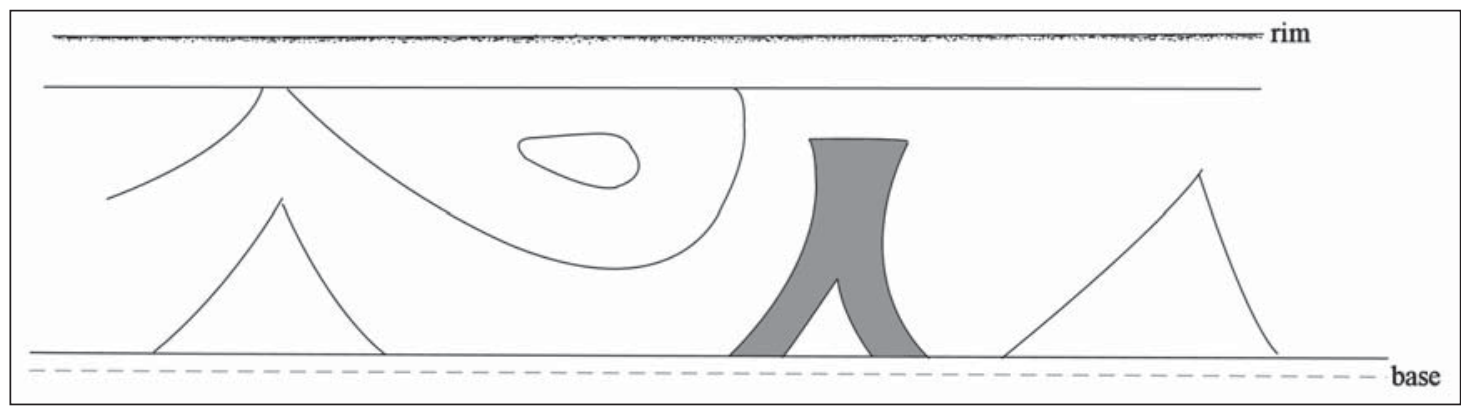

Figure 52. Engraved bowl with tear-drop motif from the Salt Lick site (16SA37a). 
SITE NAME OR SITE NUMBER: Salt Lick (16SA37a)

VESSEL NO.: Feature 13, Vessel 6, Lot 141

VESSEL FORM: Carinated bowl (see McClurkan et al. 1966:Figure 20f)

NON-PLASTICS AND PASTE: bone

RIM AND LIP FORM: Inverted rim and rounded, exterior folded lip

CORE COLOR: $\mathrm{H}$ (fired in a reducing environment and cooled in the open air)

INTERIOR SURFACE COLOR: reddish-brown

EXTERIOR SURFACE COLOR: very dark grayish-brown

WALL THICKNESS (IN MM): rim, $6.2 \mathrm{~mm}$; body, $7.0 \mathrm{~mm}$

INTERIOR SURFACE TREATMENT: smoothed

EXTERIOR SURFACE TREATMENT: smoothed

HEIGHT (IN CM): 10.2

ORIFICE DIAMETER (IN CM):

10.0

DIAMETER AT BOTTOM OF RIM

OR NECK (IN CM): 11.0

BASE DIAMETER (IN CM)

AND SHAPE OF BASE: 6.5 ;

circular and flat

ESTIMATED VOLUME (IN LI-

TERS): 0.6

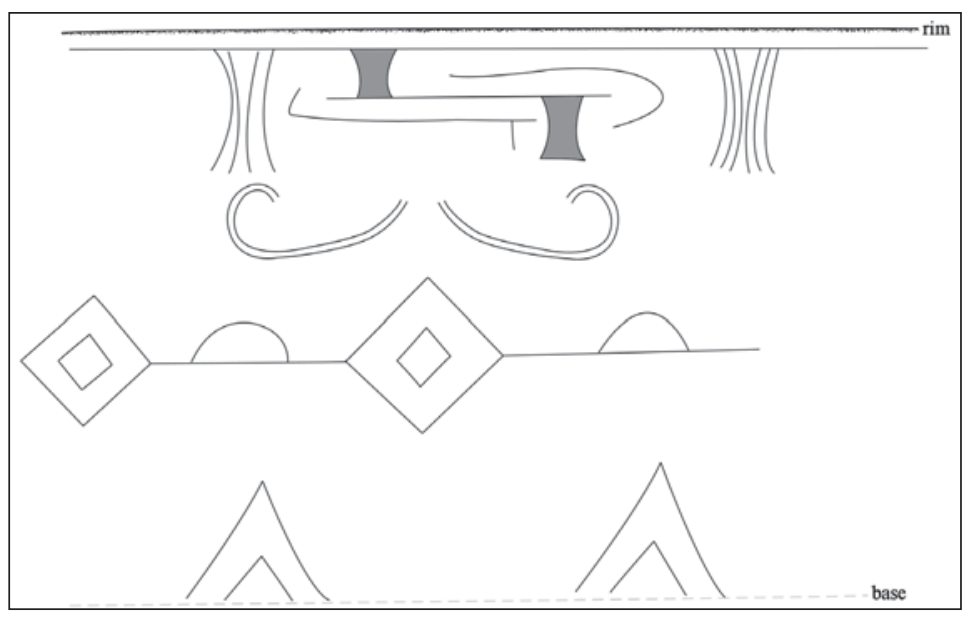

DECORATION (INCLUDING MOTIF AND ELEMENTS WHEN

Figure 53. Decorative elements on cf. Ripley Engraved, var. Pilgrims carinated bowl from the Salt Lick site (16SA37a). APPARENT): The vessel rim has an engraved horizontal interlocking scroll motif repeated three times around the vessel; the motifs are divided by brackets filled with arcing lines (Figure 53). The vessel body has a stacked series of engraved decorative elements. The first is a series of four curvilinear lines with rounded ends. The second is an alternating series of four engraved diamonds and semi-circles; the diamonds have small interior diamond elements (Figure 53). The bottom series of engraved decorations on the vessel body consists of four large triangles with a smaller triangle within each of the larger ones (Figure 53).

PIGMENT USE AND LOCATION ON VESSEL: None

TYPE AND VARIETY (IF KNOWN): cf. Ripley Engraved, var. Pilgrims 
SITE NAME OR SITE NUMBER: Salt Lick (16SA37a)

VESSEL NO.: Feature 12, Vessel 1, Lot 129

VESSEL FORM: Jar

NON-PLASTICS AND PASTE: grog

RIM AND LIP FORM: Everted rim and rounded lip

CORE COLOR: B (fired and cooled in a reducing environment)

INTERIOR SURFACE COLOR: dark grayish-brown; fire clouds on the rim and body

EXTERIOR SURFACE COLOR: black; fire clouds on the rim, body, and base; organic residue on the vessel body

WALL THICKNESS (IN MM): rim, $5.4 \mathrm{~mm}$

INTERIOR SURFACE TREATMENT: smoothed

EXTERIOR SURFACE TREATMENT: none

HEIGHT (IN CM): 14.2

ORIFICE DIAMETER

(IN CM): 13.0

DIAMETER AT BOTTOM

OF RIM OR NECK

(IN CM): 12.6

BASE DIAMETER (IN CM)

AND SHAPE OF BASE: 7.0;

circular and flat

ESTIMATED VOLUME

(IN LITERS): 1.1

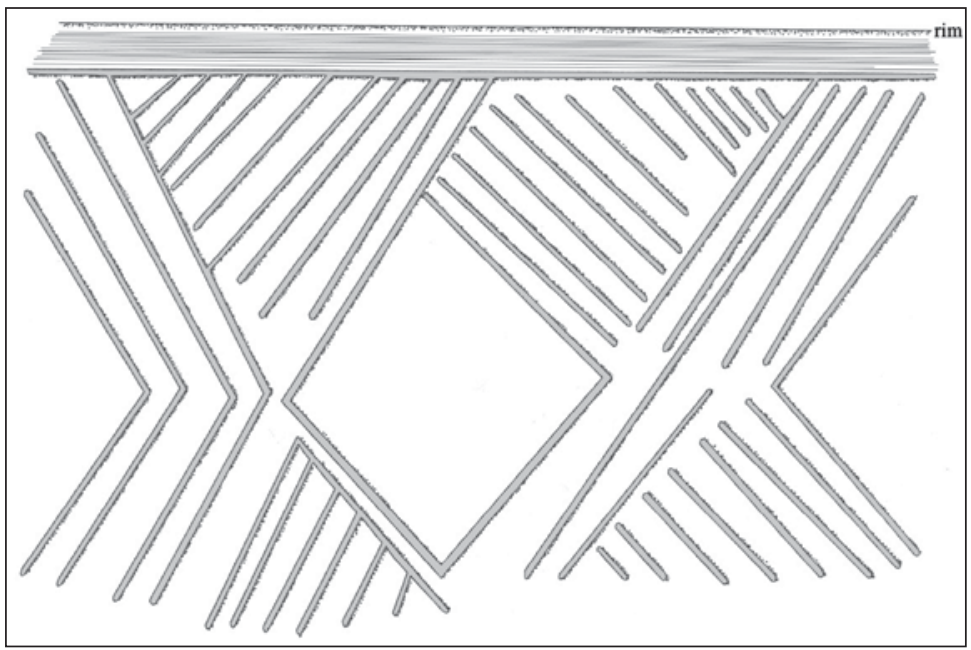

DECORATION (INCLUDING

Figure 54. Decorative elements on Pease Brushed-Incised jar from MOTIF AND ELEMENTS the Salt Lick site (16SA37a).

WHEN APPARENT): The vessel rim has horizontal brushing marks. The vessel body has five sets of upper and lower broad diagonal incised lines with open nested diamond-shaped spaces (Figure 54).

PIGMENT USE AND LOCATION ON VESSEL: None

TYPE AND VARIETY (IF KNOWN): Pease Brushed-Incised 
SITE NAME OR SITE NUMBER: Salt Lick (16SA37a)

VESSEL NO.: Unknown

VESSEL FORM: Bottle

NON-PLASTICS AND PASTE: bone and charred organics

RIM AND LIP FORM: Bottle

CORE COLOR: $F$ (fired in a reducing environment and cooled in the open air)

INTERIOR SURFACE COLOR: reddish-brown

EXTERIOR SURFACE COLOR: reddish-brown; fire clouds on the neck and body

WALL THICKNESS (IN MM): neck, $4.7 \mathrm{~mm}$; body, $4.4 \mathrm{~mm}$; base, $5.1 \mathrm{~mm}$

INTERIOR SURFACE TREATMENT: none

EXTERIOR SURFACE TREATMENT: burnished

HEIGHT (IN CM): N/A

ORIFICE DIAMETER (IN CM): 5.0

DIAMETER AT BOTTOM OF RIM OR NECK (IN CM): N/A

BASE DIAMETER (IN CM) AND SHAPE OF BASE: N/A

ESTIMATED VOLUME (IN LITERS): N/A

DECORATION (INCLUDING MOTIF AND ELEMENTS WHEN

APPARENT): The vessel body has an unknown number of nested engraved diamonds (Figure 55).

\section{PIGMENT USE AND LOCATION ON VESSEL: None}

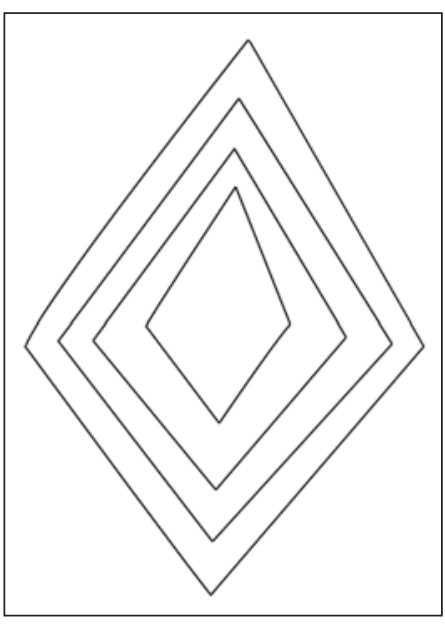

Figure 55. Decorative elements on engraved bottle from the Salt Lick site (16SA37a).

TYPE AND VARIETY (IF KNOWN): Unidentified fine ware

The two vessels from the Coral Snake Mound site (16SA48) were recovered during 1966-1967 excavations by SMU in the one mound there (Figure 56); see Jensen 1968a, 1968b). The vessels were found in two ca. 100 B.C.-A.D. 300 Woodland cremation features (Jensen 1968a:Table 9). The plain bowl came from Feature 9 in the third and final stage of mound construction and use, found in association with red ochre-stained sediments, a copper bead, and a copper-stained human tooth. The Marksville Stamped, var. Marksville jar was in Feature 16 in the primary mound (Stage 2), in association with rib fragments and a trapezoidal copper pendant. 


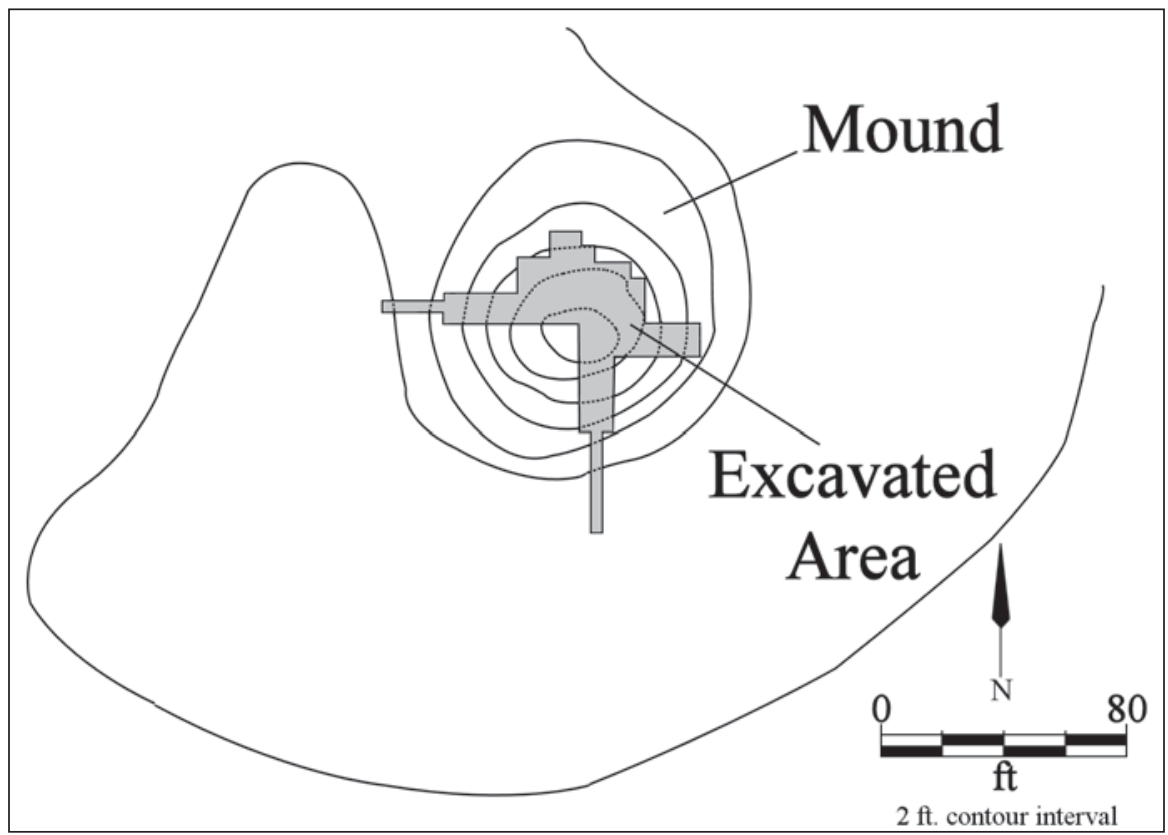

Figure 56. Excavations at the Coral Snake Mound site (16SA48).

SITE NAME OR SITE NUMBER: Coral Snake (16SA48)

VESSEL NO.: Lot 27

VESSEL FORM: Bowl (see Jensen 1968a:Figure 7h)

NON-PLASTICS AND PASTE: grog

RIM AND LIP FORM: Direct rim and flat lip

CORE COLOR: A (fired and cooled in an oxidizing environment)

INTERIOR SURFACE COLOR: reddish-brown; fire clouds on the body and base; pinkware (i.e., iron-rich clay used in vessel manufacture)

EXTERIOR SURFACE COLOR: reddish-brown; fire clouds on the rim, body, and base

WALL THICKNESS (IN MM): rim, $5.0 \mathrm{~mm}$

INTERIOR SURFACE TREATMENT: none

EXTERIOR SURFACE TREATMENT: smoothed

HEIGHT (IN CM): 5.5

ORIFICE DIAMETER (IN CM): 7.0

DIAMETER AT BOTTOM OF RIM OR NECK (IN CM): N/A

BASE DIAMETER (IN CM) AND SHAPE OF BASE: 5.0; circular and rounded 
ESTIMATED VOLUME (IN LITERS): 0.15

DECORATION (INCLUDING MOTIF AND ELEMENTS WHEN APPARENT): The vessel is plain, but there are a series of straight incised lines notching the flat lip.

PIGMENT USE AND LOCATION ON VESSEL: None

TYPE AND VARIETY (IF KNOWN): Unidentified utility ware

SITE NAME OR SITE NUMBER: Coral Snake (16SA48)

VESSEL NO.: Lot 28

VESSEL FORM: Jar (see Jensen 1968a:Figures 8 and 9)

NON-PLASTICS AND PASTE: grog

RIM AND LIP FORM: Direct rim and flat lip

CORE COLOR: B (fired and cooled in a reducing environment)

INTERIOR SURFACE COLOR: grayish-brown

EXTERIOR SURFACE COLOR: dark grayish-brown; fire clouds on the rim and body

WALL THICKNESS (IN MM): rim, $6.5 \mathrm{~mm}$

INTERIOR SURFACE TREATMENT: none

EXTERIOR SURFACE TREATMENT: none

HEIGHT (IN CM): 12.8

ORIFICE DIAMETER (IN CM): 11.8

DIAMETER AT BOTTOM OF RIM OR NECK (IN CM): 11.4

BASE DIAMETER (IN CM) AND SHAPE OF BASE: 6.0; circular and rounded

ESTIMATED VOLUME (IN LITERS): 0.9

DECORATION (INCLUDING MOTIF AND ELEMENTS WHEN APPARENT): The vessel rim has 20+ rows of small dentate stamping as well as two horizontal lines at the base of the rim (Figure 57a). There is a single row of linear punctations between the horizontal lines.

The vessel body has broad U-shaped curvilinear incised lines that have formed four sets of incised raptor heads (i.e., Hopewellian bird motif, Brown 1998:35). The raptor heads face in opposing directions on the vessel body, and are separated from each other by curvilinear and vertical incised lines and dentate stamped areas. The zones between the incised lines are filled with dentate stamping as a background for the central incised decorative element (see Figure 57a, c). 
The vessel base is encircled by three horizontal incised lines, and the outer two lines form a band filled with dentate stamping (see Figure 57b). The inner incised circle is divided into nine rectangular zones, two of which are filled with dentate stamping.

PIGMENT USE AND LOCATION ON VESSEL: None

TYPE AND VARIETY (IF KNOWN): Marksville Stamped, var. Marksville (Brown 1998:35)

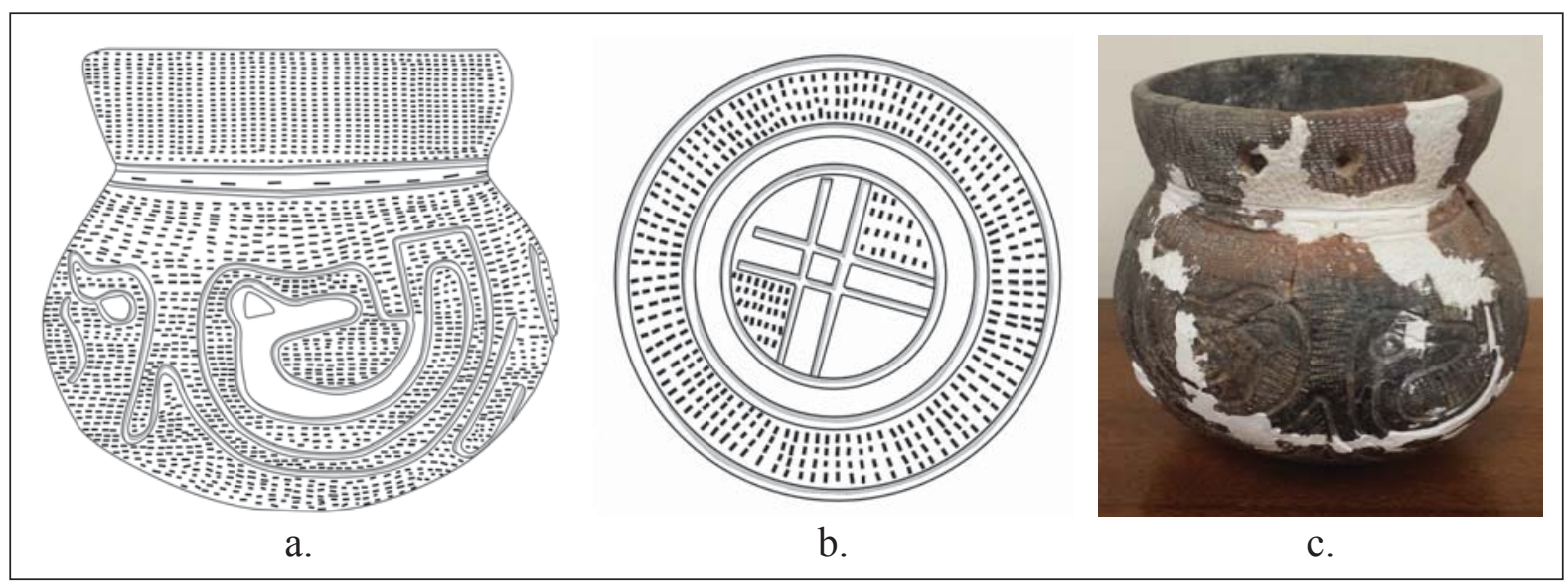

Figure 57. Decorative elements on Marksville Stamped, var. Marksville jar from the Coral Snake site (16SA48): a, body; b, base: side view.

Both of the Middle Woodland period Coral Snake vessels are small in size, and tempered with grog. One is lip-notched and the other has an incised-dentate stamped decoration featuring an incised bird or raptor. This vessel has been classified as Marksville Stamped, var. Marksville, a Lower Mississippi Valley ceramic type.

The other vessels from burial features at sites excavated at Toledo Bend Reservoir are primarily tempered with bone ( $\mathrm{n}=18,75$ percent); the remainder are tempered with grog ( $\mathrm{n}=6,25$ percent). Vessel forms represented include: compound bowl ( $\mathrm{n}=1,4$ percent), carinated bowl $(\mathrm{n}=6,25$ percent), beaker $(\mathrm{n}=1,4$ percent), bottle ( $n=5,21$ percent), bowl ( $n=4,17$ percent), jar $(n=6,25$ percent), and olla ( $n=1,4$ percent). One carinated bowl is plain, but the other 23 are decorated, either with engraved fine ware decorative elements $(n=16,70$ percent of the decorated vessels) or wet paste utility ware elements $(n=7,30$ percent). The identified fine ware types include Glassell Engraved, cf. Patton Engraved, var. Allen, Ripley Engraved (var. Caldwell, var. Gandy, and var. Pilgrims), and Wilder Engraved, while the identified utility ware types include Karnack Brushed-Incised and Pease Brushed-Incised. An engraved vessel from the Salt Lick site with a tear-drop motif (see Figure 52) is duplicated by a carinated bowl from Feature 5 at the Bison, B site (Woodall 1969:Figure 11z).

The absence of Taylor Engraved, Belcher Ridged, and Belcher Engraved ceramic types in these burial features suggest they date to the earlier part of the Late Caddo period, from ca. A.D. 1400-1500. The one cf. Patton Engraved vessel from the Salt Lick site is temporally anomalous, if the vessel is correctly identified to type, as this type is rather securely dated to post-A.D. 1560 contexts in East Texas Caddo burial features (Perttula et al. 2011), and even more so to post-A.D. 1650 times. 


\section{Other Vessels from Louisiana Caddo Sites}

Courtesy of Jeffrey S. Girard of Northwestern State University of Louisiana in Natchitoches, Louisiana, we reproduce images of other Caddo vessels from four other sites at Toledo Bend Reservoir. This includes one vessel from an unnumbered site in DeSoto Parish, nine vessels from the Bison, Area B site (16SA30) (see also Woodall 1969:Figures 11-13 for other vessels from the site), one vessel from 16SA67, and one vessel from 16SA91 (see also Girard 2007:Figure 38; Gregory 1966).

The one vessel from the DeSoto Parish site is a Sinner Linear Punctated jar (Figure 58a). The nine vessels from the Bison site, Area B include plain ware (Figure 58b), Belcher Ridged (Figure 58c), an incised bowl (Figure 58d), and a fine ware bottle of unusual shape (Figure 58e), a Taylor Engraved olla (Figure 58f), and carinated bowls (Figure 58g-j). The carinated bowls are Ripley Engraved vessels, and one of the carinated bowls has the tear-drop engraved motif also noted in a vessel at the Salt Lick site and another burial feature at the Bison, Area B site (Woodall 1969:Figure 11z). There are also Pease Brushed-Incised jars from 16SA67 (Figure 58k) and 16SA91 (Figure 581).

\section{Texas Sites}

There are 46 archaeological sites and one area (in Sabine County) that have either Woodland period (ca. 2500-1150 years B.P.) or ancestral Caddo (ca. post-1150 years B.P.) components with archaeological material remains at TARL (Table 24). Thirteen of the sites (28 percent) have Woodland period components with sandy paste Goose Creek Plain, var. unspecified ceramic sherds and/or early style arrow points (i.e., Friley points). More than 93 percent of the Toledo Bend Reservoir sites in Texas, however, have grog- and/ or bone-tempered plain and decorated ceramic vessels made by ancestral Caddo potters, and nine sites (19 percent) have Caddo style arrow points of different styles (i.e., Alba and Perdiz styles).

Table 24. Texas sites with collections at TARL from Toledo Bend Reservoir.

\begin{tabular}{|c|c|c|c|c|}
\hline Sites & $\begin{array}{l}\text { Woodland period } \\
\text { sherds }\end{array}$ & $\begin{array}{l}\text { Woodland } \\
\text { period AP }\end{array}$ & Caddo sherds & $\begin{array}{l}\text { Caddo AP/ } \\
\text { tools }\end{array}$ \\
\hline 41NW62 & - & - & $\mathrm{x}$ & $\mathrm{x}$ \\
\hline 41NW100 & - & - & $\mathrm{x}$ & - \\
\hline 41NW101 & - & - & $\mathrm{x}$ & - \\
\hline 41NW102 & $\mathrm{x}$ & - & - & - \\
\hline 41NW103 & $\mathrm{x}$ & - & $\mathrm{x}$ & - \\
\hline $41 \mathrm{PN} 8$ & - & - & $\mathrm{x}$ & - \\
\hline 41PN9 & - & - & $\mathrm{x}$ & - \\
\hline 41PN10 & - & - & $\mathrm{x}$ & - \\
\hline 41PN12 & - & - & $\mathrm{x}$ & - \\
\hline 41SB Area \# & - & - & - & $\mathrm{x}$ \\
\hline 41SB30 & - & - & $\mathrm{x}$ & - \\
\hline 41SB31 & - & - & $\mathrm{x}$ & - \\
\hline 41SB34 & - & - & $\mathrm{x}$ & - \\
\hline 41SB38 & - & - & $\mathrm{x}$ & - \\
\hline 41SB41 & $\mathrm{x}$ & - & $\mathrm{x}$ & - \\
\hline 41SB54 & $\mathrm{x}$ & - & $\mathrm{x}$ & - \\
\hline 41SB55 & - & - & $\mathrm{x}$ & - \\
\hline 41SB57 & - & - & $\mathrm{x}$ & - \\
\hline 41SB58 & $\mathrm{x}$ & - & $\mathrm{x}$ & - \\
\hline
\end{tabular}


Table 24. Texas sites with collections at TARL from Toledo Bend Reservoir, cont.

\begin{tabular}{|c|c|c|c|c|}
\hline Sites & $\begin{array}{l}\text { Woodland period } \\
\text { sherds }\end{array}$ & $\begin{array}{l}\text { Woodland } \\
\text { period AP }\end{array}$ & Caddo sherds & $\begin{array}{l}\text { Caddo AP/ } \\
\text { tools }\end{array}$ \\
\hline 41SB64 & $\mathrm{x}$ & - & $\mathrm{x}$ & $\mathrm{x}$ \\
\hline 41SB65 & $\mathrm{x}$ & - & - & - \\
\hline 41SB66 & $\mathrm{x}$ & - & $\mathrm{x}$ & - \\
\hline 41SB100 & $\mathrm{x}$ & - & $\mathrm{x}$ & $\mathrm{x}$ \\
\hline 41SB102 & $\mathrm{x}$ & - & $\mathrm{x}$ & - \\
\hline 41SB104 & $\mathrm{x}$ & - & - & - \\
\hline 41SB105 & - & - & $\mathrm{x}$ & - \\
\hline 41SB108 & - & - & $\mathrm{x}$ & - \\
\hline 41SB111 & $\mathrm{x}$ & $\mathrm{x}$ & $\mathrm{x}$ & $\mathrm{x}$ \\
\hline 41SB113 & - & - & $\mathrm{x}$ & $\mathrm{x}$ \\
\hline 41SB114 & - & - & $\mathrm{x}$ & - \\
\hline 41SY3 & - & - & $\mathrm{x}$ & - \\
\hline 41SY6 & - & - & $\mathrm{x}$ & - \\
\hline 41SY7 & - & - & $\mathrm{x}$ & - \\
\hline 41SY8 & - & - & $\mathrm{x}$ & - \\
\hline 41SY9 & - & - & $\mathrm{x}$ & - \\
\hline 41SY10 & - & - & $\mathrm{x}$ & $\mathrm{x}$ \\
\hline 41SY11 & - & - & $\mathrm{x}$ & - \\
\hline 41SY12 & - & - & $\mathrm{x}$ & - \\
\hline 41SY13 & - & - & $\mathrm{x}$ & - \\
\hline 41SY14 & - & - & $\mathrm{x}$ & - \\
\hline 41SY15 & - & - & $\mathrm{x}$ & - \\
\hline 41SY17 & - & - & $\mathrm{x}$ & - \\
\hline 41SY18 & - & - & $\mathrm{x}$ & $\mathrm{x}$ \\
\hline 41SY20 & - & - & $\mathrm{x}$ & - \\
\hline 41SY22 & - & - & $\mathrm{x}$ & - \\
\hline 41SY23 & - & - & $\mathrm{x}$ & - \\
\hline 41SY100 & $\mathrm{x}$ & - & $\mathrm{x}$ & $\mathrm{x}$ \\
\hline
\end{tabular}

$\mathrm{AP}=$ arrow point

Several sites at Toledo Bend Reservoir have Woodland period sandy paste Goose Creek Plain, var. unspecified sherds or Woodland period arrow point forms. These include:

41NW102 (a plain rim sherd from a bowl);

41NW103 (2 plain body sherds);

41SB41 (1 plain body sherd);

41SB54 (6 plain body sherds);

41 SB58 (1 plain body sherd);

41SB65 (1 plain body sherd);

41SB66 (4 plain body sherds);

41SB102 (3 plain body sherds);

41SB104 (1 plain body sherd);

41SB111 (3 plain body sherds; 1 tan chert Friley arrow point) 


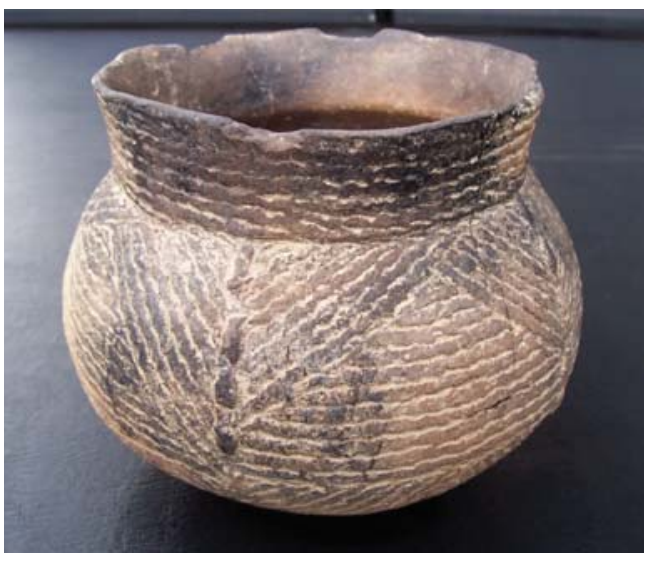

a.

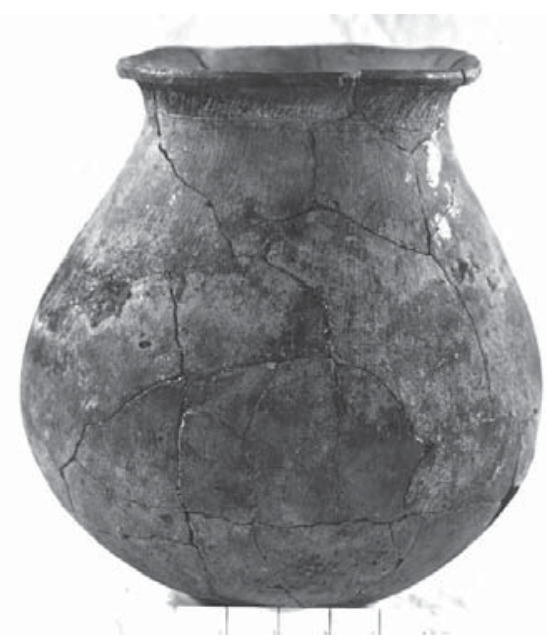

c.

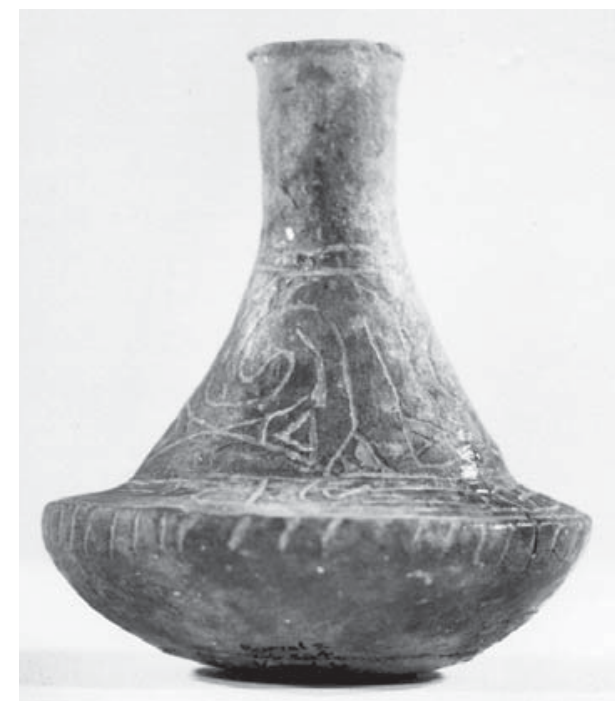

e.

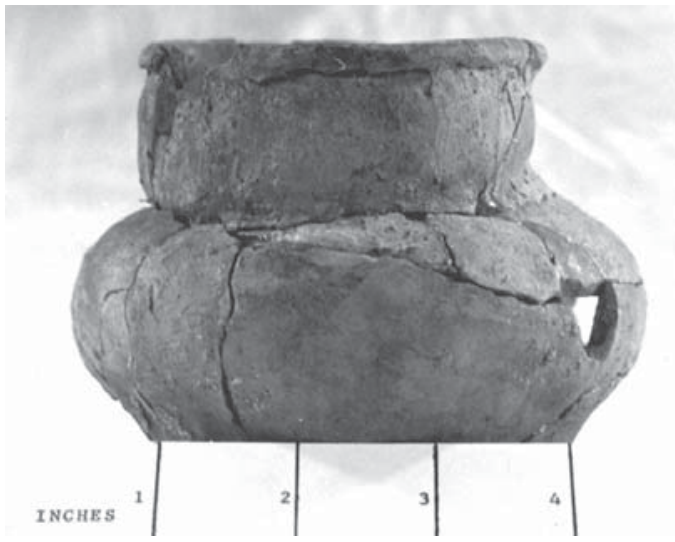

b.

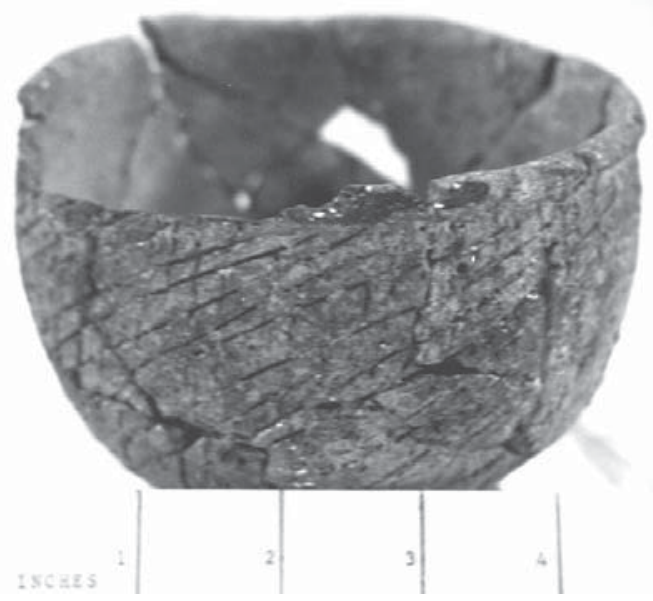

d.

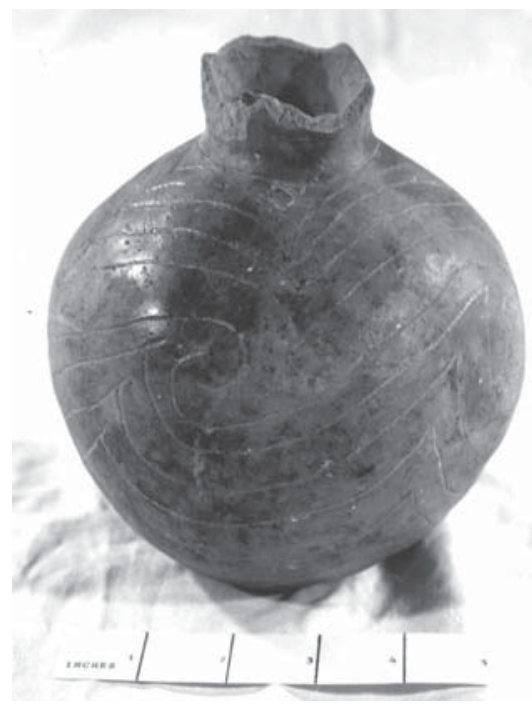

f.

Figure 58. Vessels from other Louisiana Caddo sites at Toledo Bend Reservoir: a, DeSoto Parish site; b-j, Bison, Area B (16SA30); k, 16SA67; 1, 16SA91. Photographs courtesy of Jeffrey S. Girard. 


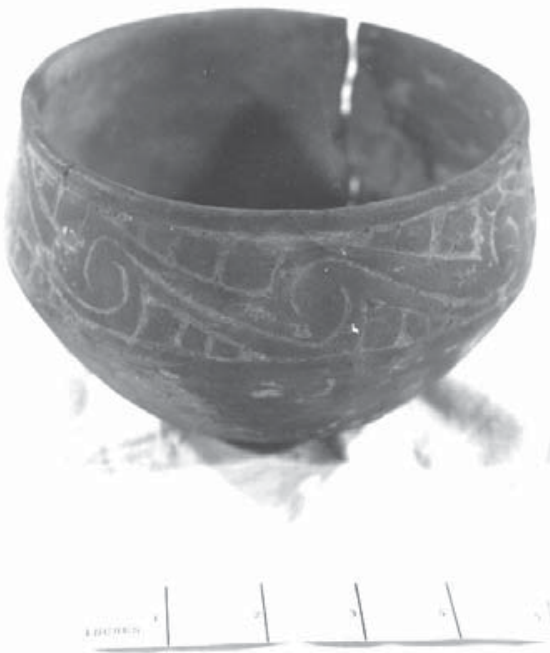

g.
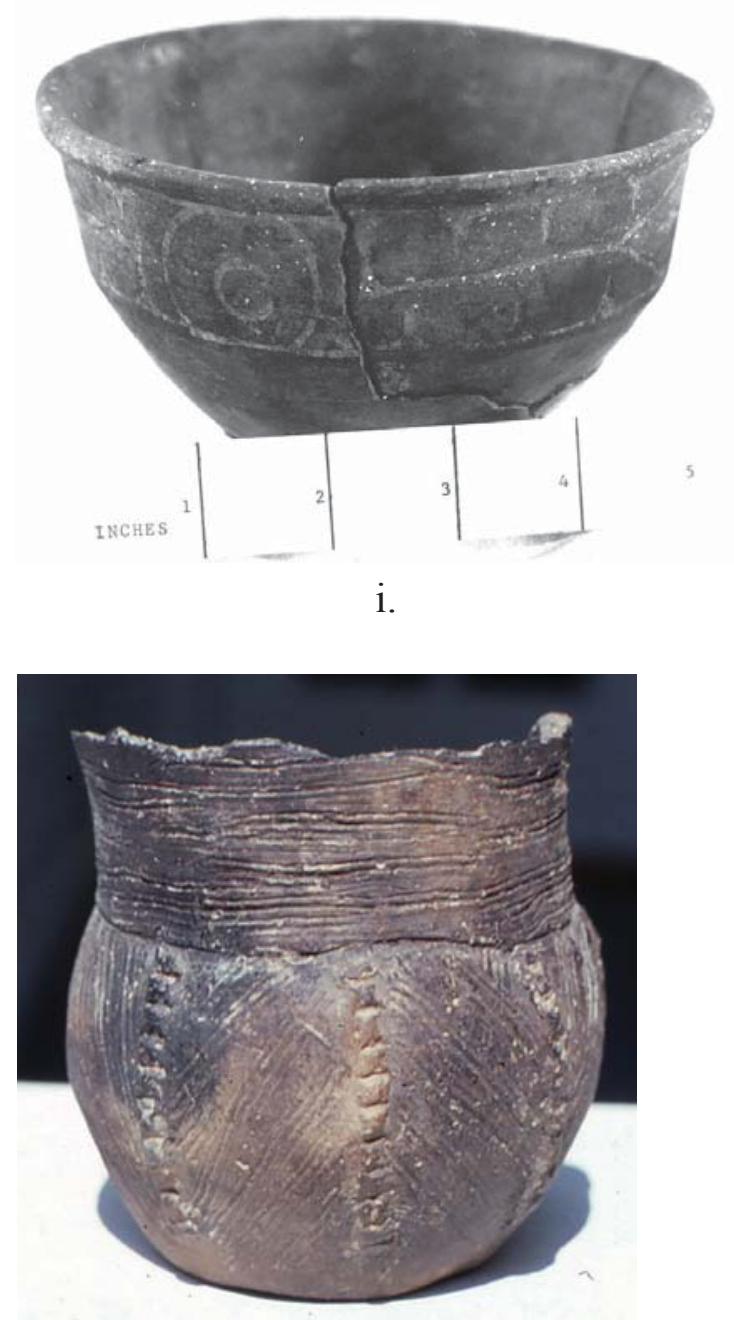

$\mathrm{k}$.

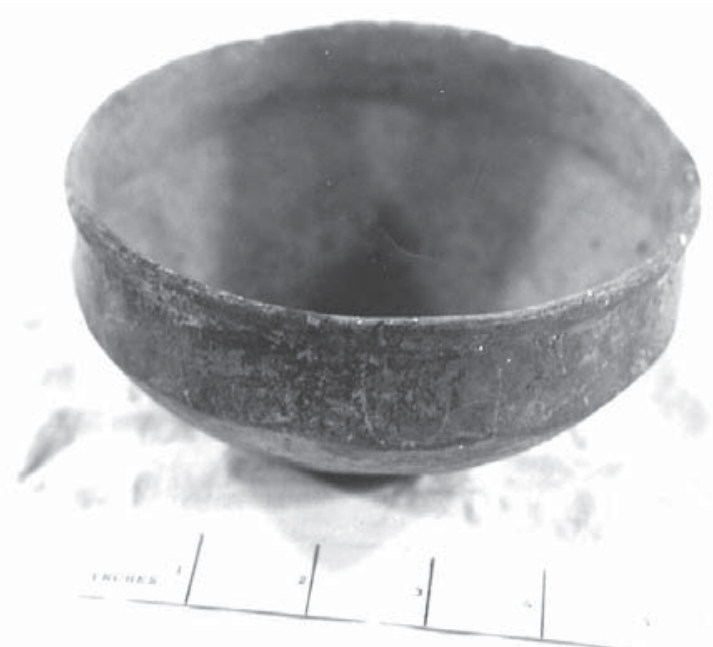

h.
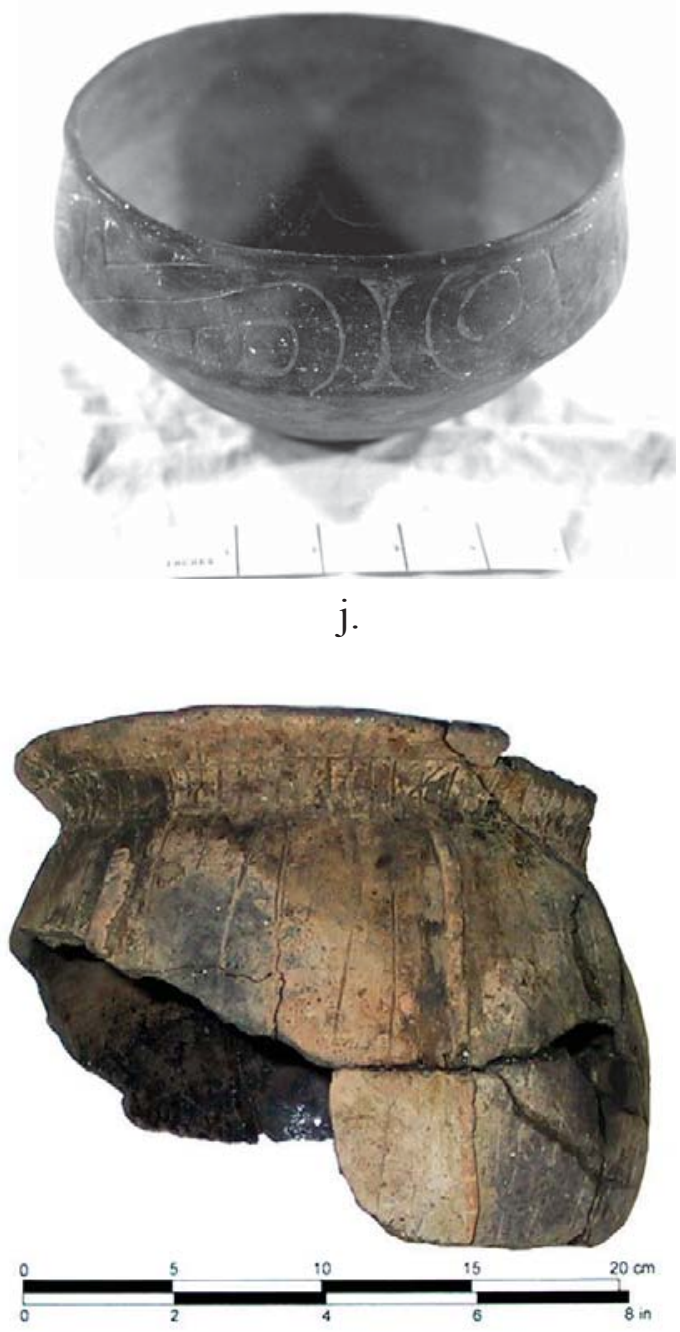

1.

Figure 58, cont. Vessels from other Louisiana Caddo sites at Toledo Bend Reservoir: a, DeSoto Parish site; b-j, Bison, Area B (16SA30); k, 16SA67; 1, 16SA91. Photographs courtesy of Jeffrey S. Girard. 
Sites with prehistoric Caddo artifacts of unknown age on the Texas side of Toledo Bend Reservoir include:

- $\quad 41 \mathrm{NW} 101$ (2 grog-tempered sherds, including 1 with parallel incised lines);

- $\quad 41 \mathrm{NW} 103$ (1 grog-tempered plain body sherd);

- $\quad 41 \mathrm{PN} 8$ (10 plain grog-tempered rim and body sherds);

- $\quad 41 \mathrm{PN} 9$ (2 plain grog or bone-tempered body sherds);

- 41PN10 (2 grog-tempered sherds, 1 with parallel incised lines; this site also has chert end and side scrapers);

- $\quad 41 \mathrm{SB} 30$ (17 plain and decorated grog-tempered body sherds, including 2 sherds with parallel incised lines; there is also a bluish-gray chert side scraper);

- $\quad 41 \mathrm{SB} 34$ (2 plain grog-tempered body sherds);

- $\quad 41 \mathrm{SB} 38$ (2 plain grog-tempered body sherds);

- $\quad 41 \mathrm{SB} 55$ (4 plain grog-tempered sherds);

- $\quad 41 \mathrm{SB} 58$ (1 plain grog-tempered rim sherd);

- $\quad$ 41SB66 (3 plain grog-tempered body sherds);

- $\quad 41 \mathrm{SB} 102$ (1 plain grog-tempered body sherd);

- $\quad 41 \mathrm{SB} 105$ (1 plain grog-tempered body sherd);

- $\quad 41 \mathrm{SB} 114$ (2 plain grog-tempered body sherds);

- $\quad 41 \mathrm{SY} 3$ (2 plain grog-tempered body sherds);

- $\quad 41 \mathrm{SY} 6$ (4 plain grog-tempered body sherds);

- $\quad 41 \mathrm{SY7}$ (3 plain grog-tempered body sherds);

- $\quad 41 \mathrm{SY} 9$ (6 plain bone-tempered body sherds);

- $\quad 41 \mathrm{SY} 11$ (2 grog-tempered sherds, 1 with a single tool punctate);

- $\quad 41 \mathrm{SY} 13$ (3 plain grog or bone-tempered body sherds);

- $\quad 41 \mathrm{SY} 14$ (1 plain bone-tempered sherd and 1 grog-tempered sherd with parallel incised lines);

- 41SY20 (1 grog-tempered engraved-punctated body sherd);

- 41SY22 (19 grog or bone-tempered sherds, 3 with incised line decorative elements); and

- $\quad 41 \mathrm{SY} 23$ (3 plain grog-tempered body sherds).

Early Caddo period (ca. A.D. 900-1200) archaeological materials are represented at:

- $\quad 41 N W 62$ (2 plain grog or bone-tempered sherds and a reddish-gray chert Alba arrow point);

- 41SB41 (3 grog-tempered body sherds, including one with a zoned incised-punctated decorative element);

- $\quad 41 \mathrm{SB} 108$ (1 opposed incised grog-tempered body sherd and 3 plain grog-tempered sherds); and

- $41 \mathrm{SB} 111$ (1 grog-tempered spindle whorl and 2 Alba arrow points, one of tan chert and the other of a heat-treated pink chert).

Post-A.D. 1200 Caddo components are present at:

- $\quad 41 \mathrm{NW} 100$ (8 grog-tempered sherds, including 2 body sherds with parallel brushed decorations);

- $\quad 41 \mathrm{SB}$ Area \# (1 gray chert Perdiz arrow point);

- $\quad 41 \mathrm{SB} 31$ (1 grog-tempered parallel brushed sherd);

- $\quad$ 41SB54 (9 grog- and bone-tempered sherds, including one with parallel brushing);

- $\quad 41 \mathrm{SY} 8$ (1 parallel brushed grog-tempered sherd);

- $\quad 41 \mathrm{SY} 10$ (1 brown chert cf. Perdiz arrow point and grog-tempered fingernail punctated body sherd); and

- $\quad 41 \mathrm{SY} 18$ (1 parallel brushed grog-tempered sherd and a parallel stemmed arrow point of red chert).

One other site on the Texas side of Toledo Bend Reservoir was occupied by Caddo peoples after ca. A.D. 1500. This is at 41SY17, which has four parallel or opposed brushed grog- and bone-tempered sherds, one 
cross-hatched engraved bottle sherd, a bone-tempered parallel incised sherd, and a grog-tempered Belcher Ridged, var. Belcher body sherd.

Most of the Texas sites at Toledo Bend Reservoir have very small TARL collections, but a few have more substantial assemblages. These assemblages are discussed in more detail in the remainder of this section.

\section{PN12}

This site was investigated during the Spring 1962 survey (Scurlock and Davis 1962:15), although it was some distance from the proposed reservoir flood pool on an upland landform in the Mill Creek drainage system. The site has a large midden deposit (ca. 1 acre); European glass trade beads had been reported by collectors from the site.

A total of 33 Caddo ceramic sherds ( 31 body sherds and two base sherds) from grog-tempered ( $\mathrm{n}=29$, 88 percent) and bone-tempered $(n=4,12$ percent) vessels. Nine of the sherds have decorative elements, including five with parallel brushing marks, one with cross-hatched incised lines, another with a curvilinear incised line, and two with incised-punctated decorative elements. One of these sherds has diagonal opposed lines, with one set of lines beginning in a row of tool punctations (Figure 59a), while the other has a circular incised zone filled with tool punctations (Figure 59b).

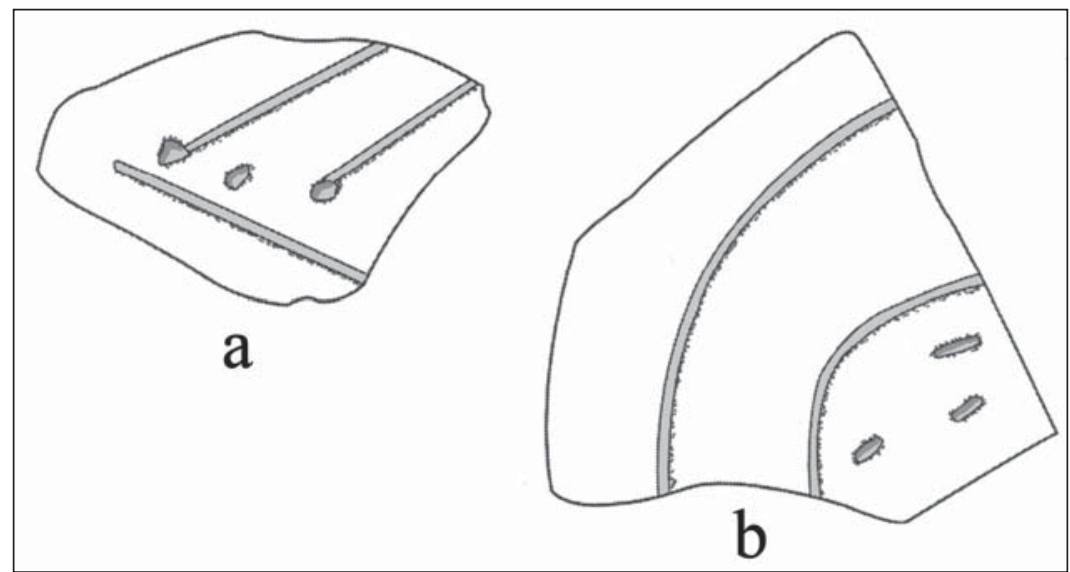

Figure 59. Decorative elements on incised-punctated body sherds from 41PN12:a-b, body sherds.

\section{$41 S B 57$}

The only archaeological work done at 41SB57 was a survey investigation in the Fall of 1961 (Scurlock and Davis 1962:30). The site is in the uplands west of Housen Bayou; a surface collection came from a road bar ditch.

A total of 13 Caddo ceramic sherds were collected at that time, from both grog-tempered $(n=8,61.5$ percent) and bone-tempered ( $\mathrm{n}=5,38.5$ percent) vessels. Four of the seven decorated sherds are from at least two post-Belcher Ridged, var. Belcher vessels. The other three decorated sherds include a rim with a horizontal engraved line below the rim, a body sherd with opposed engraved lines, and a body sherd with broad diagonally opposed incised lines. The occurrence of Belcher Ridged, var. Belcher vessel sherds at 41SB57 indicates that the ancestral Caddo occupation took place sometime after ca. A.D. 1500. 


\section{$41 S B 64$}

This site was first investigated in the Fall of 1961 by UT archaeologists (Scurlock and Davis 1962:33). It was on a small (ca. $22 \mathrm{~m}$ in diameter) alluvial rise near the Sabine River and an area of salt flats, and prehistoric artifacts were noted in a road cut that bisected the rise.

A Woodland period Mossy Grove culture occupation is indicated by a Goose Creek Plain, var. unspecified rim sherd. The remainder of the collected artifacts from the site are from an ancestral Caddo occupation and include a brown chert perforator (Figure 60) that is $49 \times 6.7 \mathrm{~mm}$ in length and width and 18 grog- $(\mathrm{n}=8,44.4$ percent) and bone-tempered ( $\mathrm{n}=10,55.6$ percent) sherds. The five decorated sherds in the small ceramic assemblage are comprised four parallel incised body sherds and a body sherd with small circular punctations.

In 1962-1963, 41SB64 received test excavations by UT archaeologists (Scurlock 1964:9-12). This consisted of a $3 \times 8 \mathrm{ft}$. trench on the southern edge of the site and another small unit on the crest of the rise. Archaeological deposits were a maximum of $45 \mathrm{~cm}$ in depth, in tan alluvial sediments. The 40 sherds found in that work included a Goose Creek Plain, var. unspecified body sherd and rim sherd and 38 Caddo vessel sherds. Only three of the sherds were decorated, all with incised elements: a rim with horizontal and vertical lines, a body sherd with curvilinear lines, and a body sherd with diagonal opposed and curvilinear lines (Figure 61).

Also recovered in the work is a bowl rim sherd from a grog-tempered Red River style long-stemmed pipe. The bowl sherd is $5.6 \mathrm{~mm}$ thick and has a direct rim and a rounded lip.

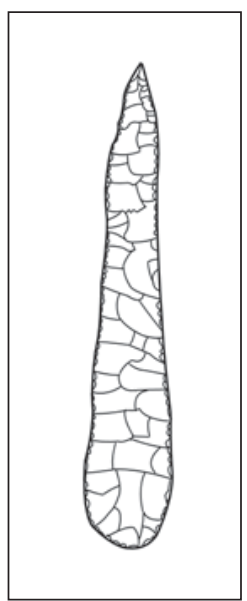

Figure 60. Chert perforator from 41SB64 at Toledo Bend Reservoir.

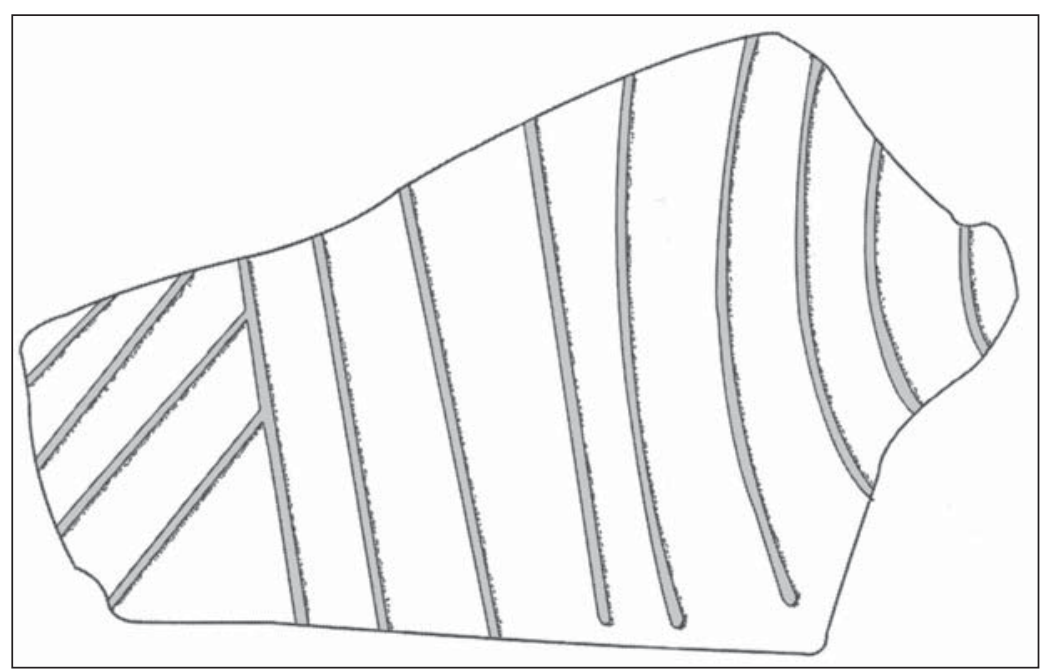

Figure 61. Incised body sherd from 41SB64.

\section{$41 S B 100$}

This site was investigated by Southern Methodist University (SMU) archaeologists during the 1967-1968 season (Benham et al. 1973:Table 1). The one ancestral Caddo sherd in the TARL collection is a grog-tempered Weches Fingernail Impressed jar lower rim-body sherd (Figure 62). A tan chert Alba arrow point is also in the collection, along with pieces of daub. These artifacts indicate that 41SB100 was used by Caddo peoples between ca. A.D. 1000-1200.

A notable find from the site is a medium ( $5.5 \mathrm{~mm}$ in diameter) opaque blue glass bead with six facets. This wire-wound bead may be related to a post-18th century use of the site by Caddo peoples. 


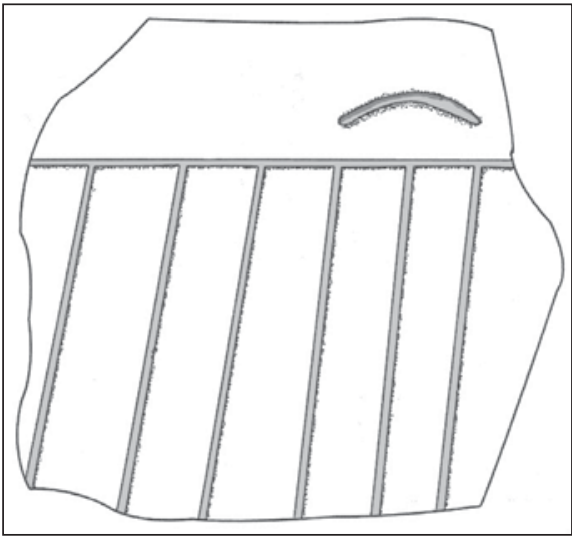

Figure 62. Weches Fingernail Impressed body sherd from $41 \mathrm{SB} 100$.

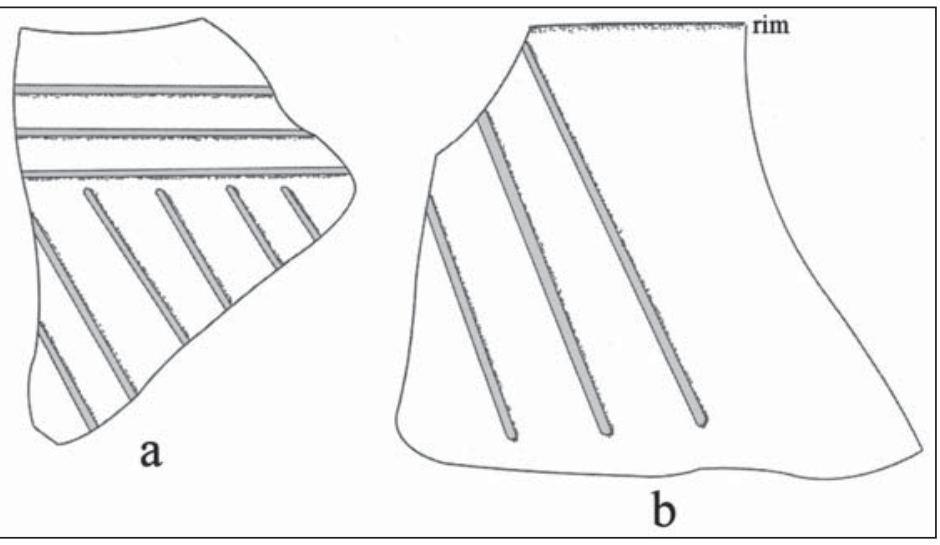

Figure 63. Incised sherds from 41SB113: a, body sherd; b, rim sherd.

\section{$41 S B 113$}

SMU archaeologists worked at 41SB113 during the 1967-1968 season at Toledo Bend Reservoir (Benham et al. 1973:Tanle 1). Recovered material culture remains from the $60 \mathrm{~m}$ diameter site include a Perdiz arrow point of tan chert and 31 ceramic sherds. The sherds are from grog- $(\mathrm{n}=29,93.5$ percent $)$ and bone-tempered $(n=2,6.5$ percent) vessels. The 10 decorated sherds in the assemblage include one fine ware body sherd with a single straight engraved line and nine utility ware sherds. These have rows of tool punctations $(\mathrm{n}=1)$, diagonal opposed incised lines $(\mathrm{n}=1$, Dunkin Incised) (Figure 63a), parallel incised lines $(n=4)$, horizontal incised lines on rim sherds $(n=2)$, and one rim from a Dunkin Incised vessel with diagonal incised lines (Figure 63b).

\section{$41 S Y 12$}

Site 41SY12 was investigated during the Spring 1962 UT archaeological survey at then proposed Toledo Bend Reservoir (Scurlock and Davis 1962:36). It was situated on an eroded upland landform. On the crest of the landform, the archaeological sediments were in deep sand, with preserved midden deposits. This work resulted in the collection of 49 ceramic sherds, both bone-tempered $(n=27,55$ percent) and grog-tempered $(n=22,45$ percent $)$.

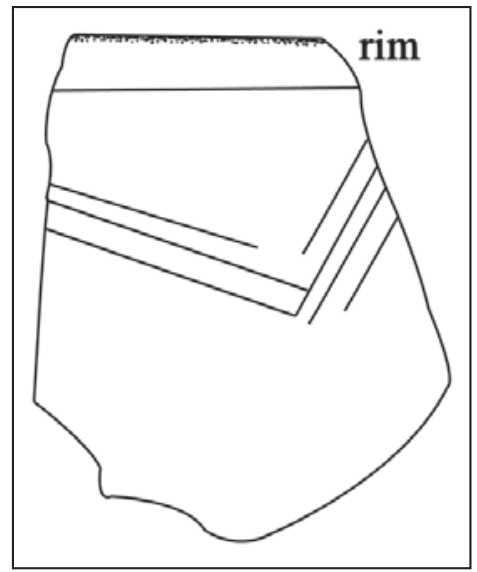

Figure 64. Engraved rim from 41SY12. 
About half of the sherds are from the decorated portions of vessels. Two are from engraved fine ware vessels, one rim with horizontal and diagonal opposed lines on the rim (Figure 64) and a body sherd with a single straight line. The other decorated sherds are from either incised (a body sherd with a straight line) or brushed vessels, including a rim with overlapping brushing marks and 20 body sherds with parallel $(\mathrm{n}=17)$ or opposed $(n=3)$ brushing marks. The high percentage of bone-tempered wares as well as the high proportion of brushed sherds in the decorated sherd assemblage ( 88 percent) suggests that 41SY12 was occupied during the Late Caddo period, probably after ca. A.D. 1600.

\section{Lafitte Site (41SY15)}

The Lafitte site (41SY15) is an ancestral Caddo mound center that was identified and recorded in the early 1960s during the course of archaeological surveys of then proposed Toledo Bend Reservoir (Scurlock 1964:12-15; Scurlock and Davis 1962:37). The Lafitte site is situated on the crest of an isolated upland ridge (ca. 270 feet amsl) that would have overlooked the Sabine River floodplain a few miles to the east and ca. $100 \mathrm{ft}$. lower in elevation. Its location on a prominent upland landform, with "a commanding view of the territory" (Middlebrook 2014:89) is similar to the placement of other "important local Caddo ceremonial centers" in this part of East Texas.

J. Dan Scurlock located the site in the Spring of 1962. He estimated the site covered a ca. 40 x $25 \mathrm{~m}$ area, but excavated no shovel tests to try to determine the areal extent of subsurface archaeological deposits at the site. The cultural features of note at the site included two earthen mounds not far from each other. The first was ca. $9.2 \mathrm{~m}$ in diameter and ca. $1.5 \mathrm{~m}$ in height (Mound B), while the other was $15.2 \mathrm{~m}$ in diameter and ca. $0.9 \mathrm{~m}$ in height (Mound A). Ancestral Caddo pottery sherds were recovered to the south of the mounds.

Although Scurlock did not investigate the two mounds at that time, their size and shape are consistent with deliberately constructed Caddo earthen mounds in East Texas. The Lafitte site may be the southernmost and easternmost of the known multiple Caddo mound centers in East Texas (Perttula 2004:Figure 13.26). The mounds may have been built to cover important structures, serve as platforms for important buildings, or were constructed to cover burial pits of the political and religious elite in a local Caddo community (cf. Middlebrook 2014:100).

Only a handful of artifacts were collected by Scurlock from the Lafitte site in 1962. The artifacts included one red chert bipolar core and 19 ceramic sherds from Caddo vessels. These sherds were primarily from bone-tempered vessels ( 74 percent), while the other sherds are from grog-tempered vessels.

Eleven of the sherds are plain body sherds, but eight rim or body sherds have decorative elements. The rim is from a bone-tempered carinated bowl with broad horizontal and vertical excised areas under the lip and on the rim itself, but no clear decorative elements; the decorative elements might be from an excised bracket. The other seven decorated sherds are body sherds from wet paste utility ware jars. Three of these sherds ( 43 percent of the utility ware sherds) have parallel brushing marks, three others have parallel incised lines, and one has a row of tool punctations.

In 1963, UT archaeologists excavated several units (5 x $5 \mathrm{ft}$.) in Mound A, documenting basket-loaded mound fill overlying an original A-horizon at about $76 \mathrm{~cm}$ bs (Scurlock 1964:13-14). In addition to pieces of daub $(n=10)$, ceramic sherds were relatively abundant in the mound deposits, particularly brushed sherds (54 percent of the 133 decorated sherds recovered in the work) and post-A.D. 1400 Late Caddo engraved sherds (Scurlock 1964:14). Most of the sherds from this assemblage are bone-tempered (65 percent).

The high proportions of bone-tempered vessel sherds as well as the frequency of brushed utility ware sherds (albeit given the very small size of the ceramic assemblage) in the Lafitte site ceramic assemblage suggests that the site dates to the Late Caddo (ca. A.D. 1400-1680) period. There are a number of such sites in the mid-Sabine and Angelina River basins (see Perttula 2015b:Figure 11), and in fact, these sites are part 
of a recently identified Late Caddo period bone-tempered and brushed ceramic tradition in East Texas. Based on investigations at the nearby Morse Mound site (41SY27), also a Caddo multiple mound center (Bruseth et al. 2000; Middlebrook 2014), and the analysis of the ceramic assemblage from mound and village contexts (Perttula and Selden 2014), it is likely that the Morse Mound and Lafitte sites were occupied contemporaneously by Caddo groups. Mean calibrated radiocarbon ages from two samples (Middlebrook 2014:100) from the Morse Mound site, as well as the results of OCR analysis of sediment samples from mound and habitation contexts (Frink and Perttula 2001) at the site, indicate it was occupied by Caddo peoples from the late 15 th century A.D. to the early 16 th century A.D.

\section{$41 S Y 100$}

41SY100 was investigated by SMU archaeologists in the 1967-1968 season at Toledo Bend Reservoir (Benham et al. 1973:Table 1). The site was located on a sandy rise above a slough near the Sabine River, and the sandy deposits were midden-stained; the midden deposits were ca. $50 \mathrm{~cm}$ thick (Benham et al. 1973:59).

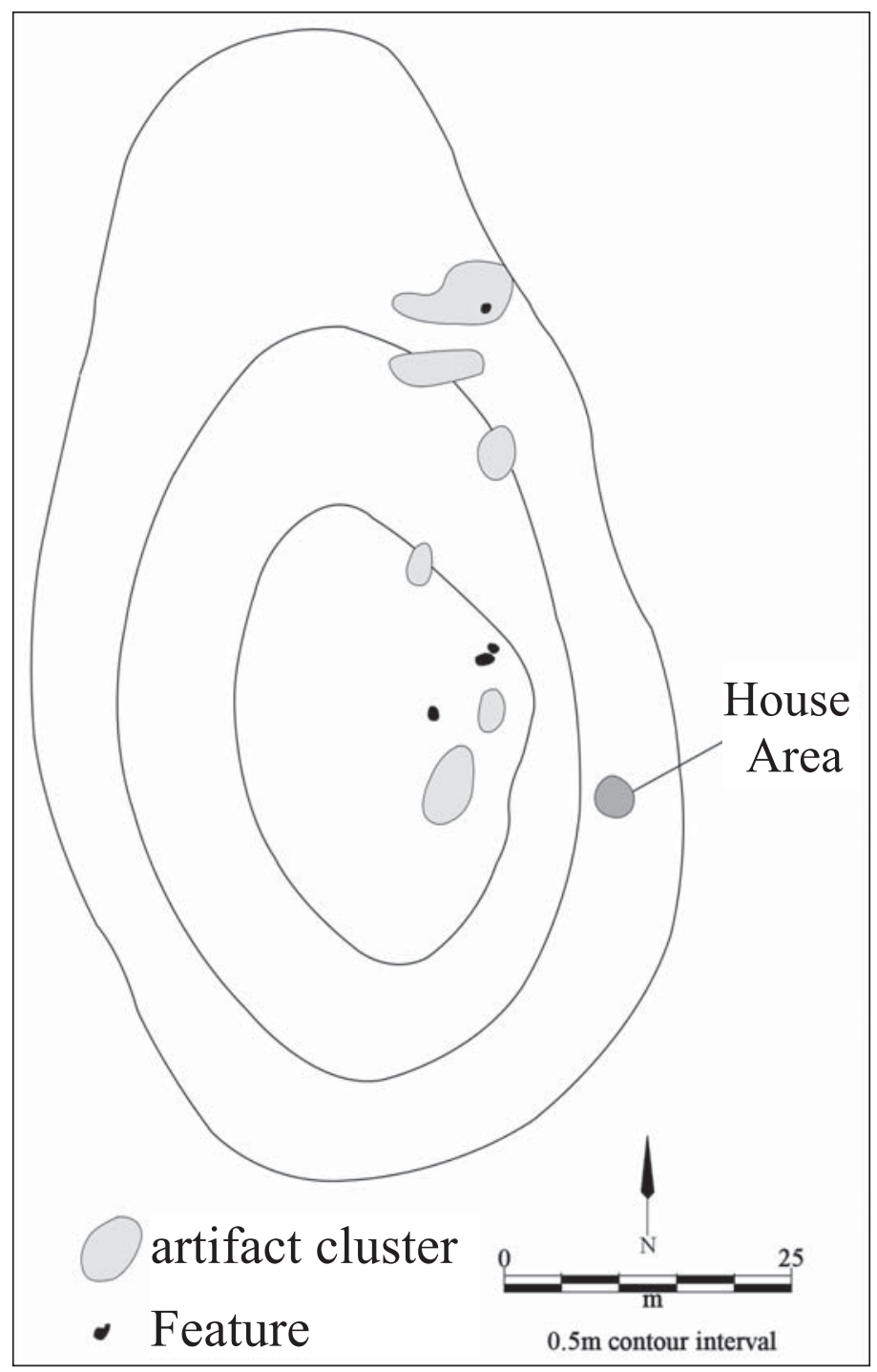

Figure 65. Map of 41SY100. 
The excavations consisted of backhoe trenching and a number of hand-excavated units on and near the crest of the natural rise (Figure 65). There were four concentrations of ash and burned clay that were probably hearths, along with several pits. A possible structure area marked by several post holes was identified on the southeastern part of the rise. In addition to the cultural features, the excavations defined six artifact clusters from north to south on the rise (Figure 65).

The Caddo ceramic assemblage from 41SY100 is dominated by sherds from grog-tempered vessels (92 percent) (Table 25). The remainder of the sherds are from bone-tempered vessels. Two of the grog-tempered plain rim sherds have drilled holes on the rim that range from 5.7-9.1 $\mathrm{mm}$ in diameter; these are likely suspension holes.

Table 25. Caddo ceramic sherd assemblage from 41SY100.

\begin{tabular}{lccc}
\hline Ware & grog-tempered & bone-tempered & $\mathrm{N}$ \\
\hline Plain & 39 & 2 & 41 \\
Utility & 18 & 2 & 20 \\
Fine & 1 & 1 & 2 \\
\hline Totals & 58 & 5 & 63 \\
\hline
\end{tabular}

Approximately 91 percent of the decorated sherds $(n=20)$ are from utility ware vessels (see Table 25$)$. Among the utility ware sherds is a body sherd with straight to curvilinear incised lines and a row of tool punctations (Figure 66a), as well as a Weches Fingernail Impressed, var. Weches rim sherd (Figure 66b). Others include horizontal incised rim and lower rim sherds $(n=4)$; vertical incised lines $(n=2)$; cross-hatched incised lines $(n=1)$; Dunkin Incised sherds with diagonal opposed incised lines $(n=3)$; parallel and straight incised lines $(n=4)$; and fingernail $(n=2)$ or tool punctated $(n=2)$ rows.

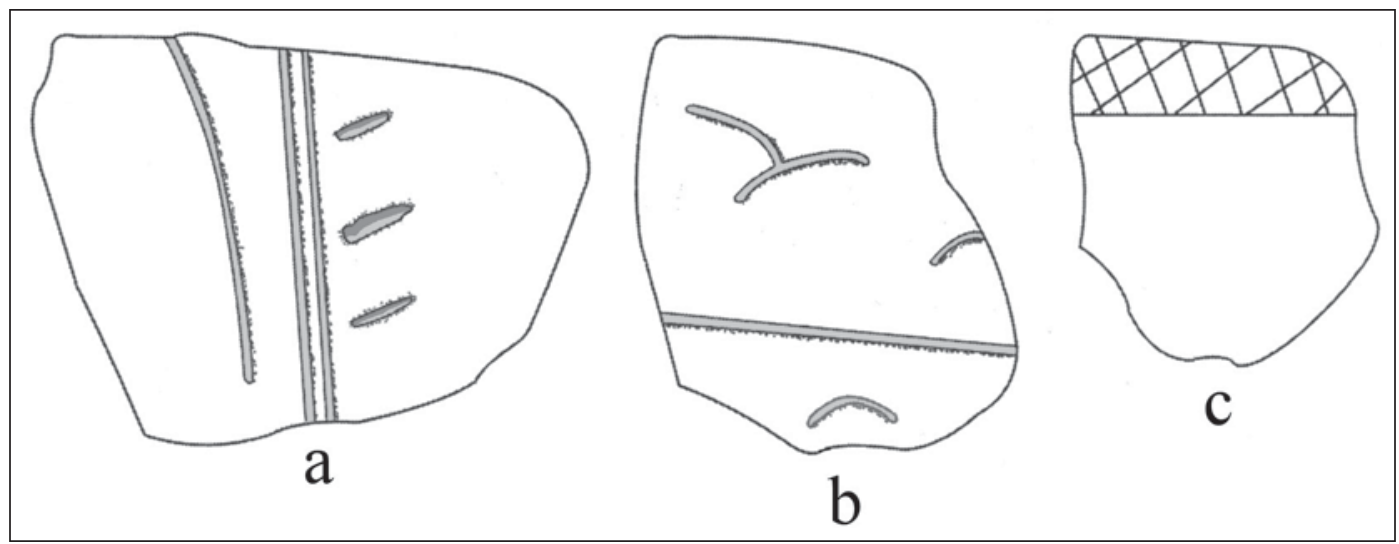

Figure 66. Decorated sherds from 41SY100: a, incised-punctated body sherd; b, Weches Fingernail Impressed rim sherd; c, cross-hatched engraved bottle sherd.

One of the fine ware sherds is from the lower rim of a carinated bowl; it has horizontal engraved lines on the rim panel. The other is a bottle sherd with a cross-hatched engraved panel (see Figure 66c), possibly from a Holly Fine Engraved vessels.

In addition to the Caddo ceramic sherds, one diagonal lip notched Goose Creek Plain, var. unspecified rim sherd is in the collection. It also has a $6.3 \mathrm{~mm}$ drilled suspension hole below the rim. 
The four arrow points in the collection from 41SY100 include a red chert blade fragment and three possible Colbert points of red chert, brown chert, and reddish-brown chert. These have slightly expanding stems, concave bases, and parallel barbs (cf. Anderson and Smith 2003:Figure 5.13w-x).

\section{SUMMARY AND CONCLUSIONS}

Archaeological investigations at sites that were to be affected by the construction of Toledo Bend Reservoir were completed in the 1960s by UT and SMU. Much of that work took place on ancestral Caddo sites on the Louisiana side of the reservoir, and these sites attest to the occupation of the middle Sabine River basin from as early as ca. 500 B.C. to as late as the late 17th century, if not later. The sites that were investigated included a Woodland period mound site and a habitation site as well as a number of Caddo settlements, family cemeteries, and one Late Caddo period mound site (Lafitte, 41SY15).

Substantial Woodland period assemblages that apparently predate ca. A.D. 300 are present at the Haddens Bend (16DS4) and Coral Snake (16SA48) sites at Toledo Bend Reservoir; a few other sites have an occasional Woodland period sherd, but no evidence of substantial use by peoples during the Woodland period. There are Marksville Plain and Marksville Stamped, var. Marksville vessels from cremations in the mound at the Coral Snake site, and sherds of Marksville Incised, Marksville Stamped, Goose Creek Incised, and Goose Creek Plain at Haddens Bend.

More substantial ceramic assemblages dating to the Early Caddo period or the Pace phase, from ca. A.D. 900-1200, are present at several sites at Toledo Bend Reservoir (Table 26). The earliest of these sites is likely the Caddo occupation at the James Pace site (16DS10), which Girard (2014) dates from ca. A.D. 800-1050. The assemblage there is dominated by high proportions of incised utility wares (73.6 percent of all the decorated sherds), including Beldeau Incised, Coles Creek Incised, Davis Incised, Dunkin Incised, and Mazique Incised, as well as sherds from Hollyknowe Ridge Pinched and Evansville Punctated vessels. Fine wares are also relatively common in this Early Caddo assemblage (15.5 percent of all the decorated sherds from the site), including sherds from Hickory Engraved and Holly Fine Engraved vessels.

Table 26. Early Caddo period decorated ceramic assemblages at Toledo Bend Reservoir.

\begin{tabular}{lllll}
\hline Sherd decoration & $16 \mathrm{DS} 9$ & $16 \mathrm{DS} 10$ & $16 \mathrm{SA} 30 \mathrm{~A}$ & $41 \mathrm{SY} 100$ \\
\hline Incised & $60.5^{*}$ & 73.6 & 34.1 & 63.6 \\
Incised-Punctated & 16.3 & 8.2 & 6.5 & 9.1 \\
Lip Notched & - & 0.3 & 0.8 & - \\
Punctated & 11.6 & 1.8 & 49.5 & 18.2 \\
Pinched & - & 0.6 & 0.8 & - \\
Engraved & 7.0 & 15.5 & 8.1 & 9.1 \\
Red-Slipped & 4.7 & - & - & - \\
\hline Totals & 43 & 330 & $123^{* *}$ & 22 \\
\hline
\end{tabular}

*percentage

**does not include decorated sherds from a small post-A.D. 1400 component at the site

Later Early Caddo sites, dating perhaps from ca. A.D. 1050-1200, have lower proportions of incised utility wares (34.1-63.6 percent) than does the James Pace site component and also they have more sherds from punctated vessels (see Table 26). Engraved fine ware sherds are overall also less common. Recognized types among the decorated sherds include Crockett Curvilinear Incised, Davis Incised, Dunkin Incised, Hickory Engraved, Holly Fine Engraved, Hollyknowe Ridge Pinched, Kiam Incised, Pennington 
Punctated-Incised, and Weches Fingernail Impressed. Although not listed in Table 26, similar decorated sherds are also present at 16SA17 and the Horatio Kunaz (16SA27) sites, but they are mixed with a more substantial number of post-A.D. 1400 Caddo ceramic sherds. None of the pre-A.D. 1200 Caddo components at Toledo Bend Reservoir have sherds from brushed vessels.

These Early Caddo period sherd assemblages are predominantly from grog-tempered vessels (91 percent). Sherds from bone-tempered vessels comprise only 9.0 percent of the plain and decorated sherds from these sites. Similar sherd assemblages have been documented from 41SB28 and 41SB38 in the Palo Gaucho and Housen bayous in the Toledo Bend Reservoir (Perttula 2015b:Table 9).

Based on the decorated ceramics, one site has a relatively unmixed Middle Caddo period component, or the Slaughter Creek phase, dating from ca. A.D. 1200-1400: 16SA101. The ceramics from this site are also predominantly from grog-tempered vessels (93.1 percent), with low amounts of sherds from bone-tempered vessels $(6.9$ percent). The decorated sherd assemblage has a few brushed sherds $(2.0$ percent, including brushed sherds with associated incised or punctated elements), but the assemblage is dominated by sherds from incised and punctated vessels (Table 27). Distinctive decorated sherds in the assemblage are from L'Eau Noire Incised and Pease Brushed-Incised utility ware vessels; the occurrence of sherds of these types at 16SA17 and Horatio Kunaz (16SA27) also suggests that they were also occupied to some extent during the Middle Caddo period. The most notable decorative elements in the fine ware vessels include hatched zones in various orientations and horizontal engraved lines with attached hatched triangles or hatched pendant triangles. These decorative elements are prevalent in Middle Caddo fine ware ceramic assemblages in much of the middle Sabine River basin.

Table 27. Middle Caddo period decorated ceramic assemblage from 16SA101.

\begin{tabular}{lll}
\hline Sherd decoration & No. & Percentage \\
\hline Brushed & 1 & 0.3 \\
Brushed-Incised & 4 & 1.4 \\
Brushed-Punctated & 1 & 0.3 \\
Incised & 216 & 74.1 \\
Incised-Punctated & 21 & 7.2 \\
Punctated & 37 & 12.7 \\
Engraved & 12 & 4.1 \\
\hline Totals & $292 *$ & 100.0 \\
\hline
\end{tabular}

*does not include one Keno Trailed sherd

Well-known Late Caddo period sites at Toledo Bend Reservoir that have both ceramic vessels and decorated sherd assemblages include Salt Lick (16SA37a) and Bison, Area B (16SA30) (McClurkan et al. 1966; Woodall 1969). On the basis of the whole vessels from these sites, the cultural affiliations of these sites may be said to exist with the Late Caddo Titus phase (perhaps its middle Sabine River manifestation at the Pine Tree Mound site community, see Fields and Gadus 2012), given the popularity of Ripley Engraved, Taylor Engraved, Karnack Brushed-Incised, and Wilder Engraved vessels in the burials (Table 28); Belcher Ridged vessels from Belcher phase sites are also funerary object inclusions in burials. However, it remains to be determined if any of these engraved vessels were locally manufactured, or were instead vessels traded to a local Caddo community that lived in this part of the Sabine River basin (see Kelley 2006; Kelley et al. 2010). 
Table 28. Ceramic vessels and sherds from the Salt Lick and Bison, Area B sites at Toledo Bend Reservoir.

\begin{tabular}{|c|c|c|c|c|}
\hline Ceramics & $\begin{array}{l}\text { Salt Lick } \\
\text { vessels }\end{array}$ & sherds & $\begin{array}{l}\text { Bison, Area B } \\
\text { vessels }\end{array}$ & sherds \\
\hline Briarfield Plain olla & 1 & - & - & - \\
\hline Unidentified Plain ware & 2 & - & 6 & - \\
\hline Subtotal & 3 & - & 6 & - \\
\hline Avery Engraved & - & - & 1 & - \\
\hline Glassell Engraved & 1 & 6 & 1 & - \\
\hline Keno Trailed & - & 25 & - & - \\
\hline Natchitoches Engraved & - & 4 & - & - \\
\hline cf. Patton Engraved & 1 & - & - & - \\
\hline cf. Ripley Engraved & 4 & - & 20 & - \\
\hline Taylor Engraved & 6 & 5 & 12 & - \\
\hline Wilder Engraved & - & - & 7 & - \\
\hline Unidentified Engraved & 4 & 216 & 10 & 264 \\
\hline Subtotal & 16 & 256 & 51 & 264 \\
\hline Belcher Ridged & - & 48 & 7 & 194 \\
\hline Bullard Brushed & - & 6 & - & - \\
\hline Cass Appliqued & - & - & 1 & - \\
\hline Cowhide Stamped & - & 1 & - & - \\
\hline Harleton Appliqued & 3 & 4 & 1 & - \\
\hline Karnack Brushed-Incised & 5 & 13 & 6 & - \\
\hline Kiam Incised & - & 6 & - & - \\
\hline Pease Brushed-Incised & 1 & 5 & 1 & - \\
\hline Pineland Punctated-Incised & - & 39 & 2 & - \\
\hline Unidentified Appliqued & - & - & - & 13 \\
\hline Unidentified Brushed & - & 295 & 1 & 349 \\
\hline Unidentified Incised & - & 462 & 4 & 393 \\
\hline $\begin{array}{l}\text { Unidentified Incised- } \\
\text { Punctated }\end{array}$ & - & 17 & - & - \\
\hline Unidentified Punctated & - & 58 & 1 & 50 \\
\hline Subtotal & 9 & 954 & 24 & 999 \\
\hline Totals & 28 & 1210 & 81 & 1263 \\
\hline
\end{tabular}

There are other vessels from the Goode (16SA1), Bison, Area B (16SA30), Salt Lick (16SA37a), and Coral Snake (16SA48) sites at Toledo Bend Reservoir. With the exception of the two vessels from the Coral Snake site that date to the early part of the Middle Woodland period (ca. 100 B.C. to A.D. 100), the other vessels are from post-A.D. 1400 Late Caddo period burial features at the other three sites.

The sherds from domestic contexts at these sites, as well as at the nearby Burnitt site (16SA204; Kelley 2006; Kelley et al. 2010), are dominated by typologically unidentifiable fine ware and utility ware sherds as well as Belcher Ridged, incised, brushed, and Pineland Punctated-Incised sherds (see Table 28). The proportion of ridged utility wares is suggestive of cultural connections with Belcher phase Caddo groups on the Red River to the east and northeast (cf. Webb 1959). 
Post-A.D. 1400/1430 Caddo archaeological sites at Toledo Bend Reservoir are included in a Salt Lick phase. Recognized decorated types in these sites include Belcher Ridged, Glassell Engraved, Keno Trailed, Mound Tract Incised and Brushed, Pease Brushed-Incised, Pineland Punctated-Incised, Ripley Engraved, and Taylor Engraved. Vessels in our analyzed set include Karnack Brushed-Incised, Pease Brushed-Incised, Ripley Engraved, and Wilder Engraved; there are also cf. Patton Engraved and cf. Womack Engraved vessels. The majority of the vessels are bone-tempered, while most of the sherds from domestic assemblages are from grog-tempered vessels. Only at the Salt Works Lake site (16SA47) are sherds from bone-tempered vessels more common in domestic contexts than grog-tempered vessels.

There are three groups of Late Caddo period decorated sherd assemblages in the Toledo Bend Reservoir sites examined in this study. The first and probably earliest of the groups are the assemblages from 16SA17 and the Horatio Kunaz site (16SA27). These two assemblages are primarily from grog-tempered vessels (87.1 percent); sherds from bone-tempered vessels account for 12.9 percent of the sample. Fine ware sherds are far from abundant (between 2.8-7.7 percent of the decorated sherds), and sherds from incised vessels are by far the most common decorated methods represented in the two assemblages (49.0-57.3 percent of all the decorated sherds) (Table 29). Sherds with brushed decorative elements, including sherds with brushing and either appliqued, incised, or punctated elements, only account for between 13.1-16.8 percent of the decorated sherds. Belcher Ridged sherds are rare: 0.8-1.3 percent; they include both var. Byram Ferry and var. Belcher.

Table 29. Comparison of Late Caddo period decorated sherd assemblages from Toledo Bend Reservoir.

\begin{tabular}{llllll}
\hline $\begin{array}{l}\text { Sherd } \\
\text { Decoration }\end{array}$ & $16 \mathrm{SA37a}$ & $16 \mathrm{SA30B}$ & $16 \mathrm{SA} 17$ & $16 \mathrm{SA} 27$ & $16 \mathrm{SA} 47$ \\
\hline $\begin{array}{l}\text { Engraved } \\
\text { Red-Slipped } \\
\text { Trailed }\end{array}$ & 19.1 & 20.8 & 2.7 & 7.2 & 28.0 \\
& - & - & 0.1 & - & - \\
Appliqued & 2.1 & - & Trace & 0.5 & 2.5 \\
Appliqued-Incised & 0.3 & 1.0 & 1.0 & 0.5 & 1.2 \\
Brushed & - & - & 1.6 & 2.9 & - \\
Brushed-Appliqued & 24.9 & 27.6 & 11.1 & 14.1 & 46.6 \\
Brushed-Incised & - & - & 1.6 & 1.6 & - \\
Brushed-Punctated & - & 0.0 & Trace & 1.1 & 5.6 \\
Grooved & - & - & 0.4 & - & - \\
Incised & 38.7 & - & 0.1 & - & 9.3 \\
Incised-Punctated & 4.6 & - & 57.3 & 49.0 & 2.5 \\
Lip Notched & - & - & 10.5 & 17.0 & - \\
Pinched & - & - & 0.1 & - & - \\
Punctated & 4.8 & 4.0 & 0.2 & Trace & 1.2 \\
Ridged & 4.0 & 15.4 & $0.8 *$ & 1.2 & $4.4^{*}$ \\
Stamped & 0.1 & - & - & - & - \\
\hline Totals & 1210 & 1263 & 2904 & 377 & 161 \\
\hline
\end{tabular}

*includes Ridged-Brushed sherds (i.e., Belcher Ridged, var. Byram Ferry).

The second group of Late Caddo period ceramic assemblages include the Bison, Area B (16SA30), Salt Lick (16SA37a), and Salt Works Lake (16SA47) sites (see Table 29). At these sites, sherds from bone-tempered vessels are more common than at any other time, as 34 percent of the sherds from the Salt Lick and Salt Works Lake site are from bone-tempered vessels; at Salt Works Lake, 63 percent of the sherds have bone temper. Bone temper has also been shown to be most common in post-A.D. 1400 Caddo sites on Palo 
Gaucho Bayou, particularly in the youngest site in the temporal sequence: 41SB29 (see Perttula 2015b:Table 9). The oldest sites, in Palo Gaucho and Housen bayous, apparently predating ca. A.D. 1200, have very little bone temper (2.4-9.4 percent) in the ceramic assemblages. Thus, through time, the use of bone temper by Caddo potters in these parts of the mid-Sabine River basin increased by more than 33-40 percent from sometime prior to A.D. 1200 to after ca. A.D. 1400 in the Palo Gaucho Bayou and 15 percent in the Housen Bayou sites. In the Louisiana sites, the use of bone temper increased from 6.9 percent in Middle Caddo period times to as much as 34 percent in one group of Late Caddo period sherd assemblages and as much as 75 percent in a sample of Late Caddo period vessels primarily from the Salt Lick site.

These particular assemblages have considerable amounts of brushed pottery: between 26.4-52.2 percent of all the decorated sherds (see Table 29). Belcher Ridged sherds are generally well represented (4.0-15.4 percent of the decorated sherds), as are sherds with incised decorated elements; sherds from incised-punctated vessels are uncommon, considerably different than is the case in the first group of Late Caddo period ceramic assemblages. Fine wares, including both sherds from engraved (19.1-28.0 percent of the decorated sherds) and trailed sherds (2.1-2.5 percent of the decorated sherds), are relatively abundant.

The third and last group of Late Caddo period ceramic assemblages at Toledo Bend Reservoir is distinctive because of the very high proportions of brushed decorated sherds (Table 30) and the absence of Belcher Ridged sherds, unlike the previously discussed group of Late Caddo sherd assemblages that all have some amount of Belcher Ridged jar sherds (see Table 29). Sherds from vessels with brushing (alone, or in combination with appliqued or punctated decorative elements) comprise between 54.1 percent and 80.7 percent of all the decorated sherds from the sites. Other than sherds from incised vessels (11.9-13.4 percent of the decorated sherds), other utility wares or fine ware sherds are not well represented in this last group of Late Caddo sites.

Table 30. Other Late Caddo period decorated sherd assemblages from Toledo Bend Reservoir.

\begin{tabular}{llll}
\hline Sherd decoration & $16 \mathrm{DS} 4$ & $41 \mathrm{SY} 15$ & $41 \mathrm{SY} 16$ \\
\hline Engraved & 1.5 & $*$ & 5.1 \\
& & & 79.6 \\
Brushed & 67.2 & 54.1 & - \\
Brushed-Appliqued & 9.0 & $?$ & 0.8 \\
Brushed-Punctated & 4.5 & $?$ & 11.9 \\
Incised & 13.4 & $*$ & - \\
Incised-Punctated & 1.5 & $?$ & - \\
Lip Notched & 1.5 & $?$ & 1.7 \\
Punctated & 1.5 & $*$ & 118 \\
\hline Totals & 67 & 133 & \\
\hline
\end{tabular}

*counts not provided in Scurlock (1964), but noted as present

The very high proportions of brushed sherds in this last set of Late Caddo period ceramic assemblages (see Table 30) would suggest that they date late in the period, but radiocarbon dates would be needed to confirm this. The use of bone temper in vessel manufacture is 17.7 percent of the sherds from the Haddens Bend site (16DS4), intermediate in proportion between the first and second groups of Late Caddo period sites. On the other hand, the absence of Belcher Ridged sherds from assemblages with a reasonable decorated sherd sample size would seem to suggest that these sites were occupied during the early part of the Late Caddo period — from ca. A.D. 1400-1500 — but were dominated by brushed utility wares.

The assemblage-level divisions in the decorated ceramic sherds we have made from the samples of sherds in the TARL collections from Toledo Bend Reservoir may have utility in sorting out of temporal and cultural 
affiliations of the many ancestral Caddo sites in the middle reaches of the Sabine River basin. Focusing in further detail on specific decorative elements, especially in the utility wares, may also have cultural historical significance regarding the material culture character of local Caddo groups. Such analyses ought to be continued with the archaeological assemblages from Toledo Bend Reservoir curated by Southern Methodist University, as these remain to be fully described and thus warrant restudy. Until these assemblages of sherds and vessels can be restudied in detail, it will remain to be determined what representative assemblages of ceramic fine ware and utility ware vessels and sherds from this part of the Sabine River basin looks like during the Pace (Early Caddo period), Slaughter Creek (Middle Caddo period), and Salt Lick (Late Caddo period) phases, which would help answer the question of the differing affiliations of the local Caddo groups living along this part of the Sabine River basin.

\section{ACKNOWLEDGMENTS}

We appreciate the assistance provided by Mary Beth Tomka and Jonathan Jarvis of TARL in facilitating access to the collections and records from Toledo Bend Reservoir sites. Robert Cast of the Caddo Nation of Oklahoma granted us permission to study the vessels curated ay TARL from burial features at the sites; as mentioned above, the vessels and ceramic sherds held by SMU from Toledo Bend Reservoir sites have yet to be fully documented in recent years. Lance Trask prepared most of the figures in this article, and Jeff Girard provided images of ceramic vessels from various Louisiana Toledo Bend Reservoir sites.

\section{REFERENCES CITED}

Anderson, D. G. and S. D. Smith

2003 Archaeology, History, and Predictive Modeling: Research at Fort Polk, 1972-2002. University of Alabama Press, Tuscaloosa.

Aten, L. E. and C. N. Bollich

2011 Early Ceramic Sites of the Sabine Lake Area, Coastal Texas and Louisiana. Studies in Archeology 43. Texas Archeological Research Laboratory, The University of Texas at Austin.

Benham, B. L., H. L. Miller, and J. V Sciscenti

1973 Archaeological Research in the Toledo Bend Reservoir. Archaeology Research Program, Southern Methodist University, Dallas.

Brown, I. W.

1998 Decorated Pottery of the Lower Mississippi Valley: A Sorting Manual. Mississippi Archaeological Association and Mississippi Department of Archives and History, Jackson.

Brown, K. M.

1976 Fused Volcanic Glass from the Manning Formation. Bulletin of the Texas Archeological Society 47:189207.

Bruseth, J. E. and T. K. Perttula

2006 Archeological Investigations at the Hudnall-Pirtle Site (41RK4): An Early Caddo Mound Center in Northeast Texas. Caddo Archeology Journal 15:57-158.

Bruseth, J., M. Parsons, T. Middlebrook, and B. Martin

2000 Unprecedented Find Uncovered at the Ronald and Kay Morse Site (41SY27). Current Archeology in Texas 2(1):4-7. 
Fields, R. C. and E. F. Gadus (editors)

2012 Archeology of the Nadaco Caddo: The View from the Pine Tree Mound Site (41HS15), Harrison County, Texas. 2 Vols. Reports of Investigations No. 164. Prewitt and Associates, Inc., Austin.

Frink, D. and T. K. Perttula

2001 Analysis of the 39 Oxidizable Carbon Ratio Dates from Mound A, Mound B, and the Village Area at the Calvin Davis or Morse Mounds Site (41SY27). North American Archaeologist 22(2):143-160.

Girard, J. S.

1992 Regional Archaeology Program, Management Unit 1: Third Annual Report. Northwestern State University, Natchitoches.

1994 Investigations at the James Pace Site (16DS268), DeSoto Parish, Louisiana. Caddoan Archeology Newsletter 5(1):8-16.

2007a Regional Archaeology Program, Management Unit 1: Eighteenth Annual Report. Report on file at the Louisiana Division of Archaeology, Department of Culture, Recreation, and Tourism, Baton Rouge.

2007b Byram Ferry (16BO17): A Middle to Late Caddo Period Mound Site in the Red River Floodplain, Northwest Louisiana. Caddo Archeology Journal 16:9-25.

2014 The James Pace Site (16DS268) and Early Caddo Developments Along the Upper Sabine River. Bulletin of the Texas Archeological Society 85:61-81.

Gregory, H. F.

1966 Vessels from the Bison Site. Louisiana Studies 5(2):159-161.

Jelks, E. B.

1965 The Archeology of McGee Bend Reservoir, Texas. Ph.D. dissertation, Department of Anthropology, The University of Texas at Austin.

Jensen, H. E.

1968a Coral Snake Mound (X16SA48). Bulletin of the Texas Archeological Society 39:9-44.

1968b Archaeological Investigations in the Toledo Bend Reservoir: 1966-1967. Archaeology Salvage Project, Southern Methodist University, Dallas.

Kelley, D. B.

2006 The Burnitt Site: A Late Caddoan Occupation in the Uplands of the Sabine River Basin of Louisiana. Coastal Environments, Inc., Baton Rouge.

Kelley, D. B. (editor)

1997 Two Caddoan Farmsteads in the Red River Valley: The Archeology of the McLelland and Joe Clark Sites. Research Series No. 51. Arkansas Archeological Survey, Fayetteville.

Kelley, D. B., D. G. Hunter, K. M. Roberts, S. L. Scott, and B. S. Haley

2010 The Burnitt Site (16SA204): A Late Caddoan Occupation in the Uplands of the Sabine River Basin. Louisiana Archaeology 31:4-33.

McClurkan, B. B., W. T. Field, and J. N. Woodall

1966 Excavations in Toledo Bend Reservoir, 1964-65. Papers of the Texas Archeological Salvage Project No. 8. Texas Archeological Salvage Project, The University of Texas at Austin.

Middlebrook, T. A.

2014 Early European Descriptions of Hasinai Elites and Understanding Prehistoric Caddo Mortuary Practices in Shelby County, Texas. Bulletin of the Texas Archeological Society 85:83-110.

Newell, H. P. and A. D. Krieger

1949 The George C. Davis Site, Cherokee County, Texas. Memoirs No. 5. Society of American Archaeology, Menasha, Wisconsin. 
Perttula, T. K.

2004 The Prehistoric and Caddoan Archeology of the Northeast Texas Pineywoods. In The Prehistory of Texas, edited by T. K. Perttula, pp. 370-407. Texas A\&M University Press, College Station.

2013 Caddo Ceramics in East Texas. Bulletin of the Texas Archeological Society 84:181-212.

2015a East Texas Caddo Ceramic Sherd Database. Journal of Northeast Texas Archaeology 51:1-46.

2015b Caddo Sites on Patroon, Palo Gaucho, and Housen Bayous in Sabine County in the Sabine River Basin of East Texas. Journal of Northeast Texas Archaeology 54:63-91.

Perttula, T. K. (assembler)

2011 Archaeological and Archaeogeophysical Investigations at an Early Caddo Mound Center in the Sabine River Basin of East Texas. Special Publication No. 15. Friends of Northeast Texas Archaeology, Austin and Pittsburg.

Perttula, T. K. (editor)

2008 Lake Naconiche Archeology, Nacogdoches County, Texas: Results of the Data Recovery Excavations at Five Prehistoric Archeological Sites. 2 Vols. Report of Investigations No. 60. Archeological \& Environmental Consultants, LLC, Austin.

Perttula, T. K. and R. Z. Selden Jr.

2014 Ceramic Sherds from the Morse Mounds Site (41SY27). Center for Regional Heritage Research, Research Report No. 3. Stephen F. Austin State University, Nacogdoches.

Perttula, T. K., D. B. Kelley, and R. A. Ricklis (assemblers and editors)

2011 Archeological Investigations at the Lang Pasture Site (41AN38) in the Upper Neches River Basin of East Texas. Report No. 129. Texas Department of Transportation, Archeological Studies Program, Environmental Affairs Division, Austin.

Perttula, T. K., M. Walters, and B. Nelson

2012 Little Cypress Creek Basin Archaeology: Six Late Caddo Period Cemeteries in Upshur County, Texas. Special Publication No. 22. Friends of Northeast Texas Archaeology, Pittsburg and Austin.

Phillips, P.

1970 Archaeological Survey in the Lower Yazoo Basin, Mississippi, 1949-1955. Papers of the Peabody Museum of Archaeology and Ethnology, Volume 60. Peabody Museum of Archaeology and Ethnology, Harvard University, Cambridge.

Robinson, D. G.

1997 Cultural Resource Investigations at the Ducks Unlimited Marsh (DUM) Project, North Toledo Bend Reservoir, Shelby County, Texas. Report 97-3. Cultural Resource Program, Texas Parks and Wildlife Department, Austin.

Scurlock, J. D.

1964 Archeological Reconnaissance at Toledo Bend Reservoir, 1962-1963 Season. Texas Archeological Salvage Project, The University of Texas at Austin.

Scurlock, J. D. and W. A. Davis

1962 Appraisal of the Archeological Resources of Toledo Bend Reservoir, Panola, Newton, Sabine, and Shelby Counties, Texas; Sabine and DeSoto Parishes, Louisiana. Texas Archeological Salvage Project, The University of Texas at Austin.

Suhm, D. A. and E. B. Jelks (editors)

1962 Handbook of Texas Archeology: Type Descriptions. Special Publication No. 1, Texas Archeological Society, and Bulletin No. 4, Texas Memorial Museum, Austin. Reprinted in 2009, Gustav's Library, Davenport, Iowa. 
Thurmond, J. P.

1990 Archeology of the Cypress Creek Drainage Basin, Northeastern Texas and Northwestern Louisiana. Studies in Archeology 5. Texas Archeological Research Laboratory, The University of Texas at Austin.

Webb, C. H.

1959 The Belcher Mound, a Stratified Caddoan Site in Caddo Parish, Louisiana. Memoirs No. 16. Society for American Archaeology, Salt Lake City.

1963 The Smithport Landing Site: An Alto Focus Component in DeSoto Parish, Louisiana. Bulletin of the Texas Archeological Society 34:143-187.

Woodall, J. N.

1969 Archeological Excavations in the Toledo Bend Reservoir, 1966. Contributions in Anthropology No. 3. Department of Anthropology, Southern Methodist University, Dallas. 